\title{
Introducción de los Esclavos negros africanos en el reino de Guatemala y provincias de San Salvador y Honduras.
}

\author{
Dr. Sigfredo Cabrera Rajo \\ Doctor en Historia de América, Universitat de Barcelona, España. \\ Investigador histórico en el Archivo General de Indias, Sevilla. \\ sigfredocabrera@yahoo.es
}

DOI: http://dx.doi.org/10.5377/koot.v0i8.5872

URI: http://hdl.handle.net/11298/386

\section{Resumen}

El Salvador no tiene Historia Moderna, por falta de la memoria histórica. Muy poco se ha escrito e investigado sobre la introducción de africanos en Guatemala, El Salvador y Honduras, el tema fue tratado por los historiadores de la Universidad Tecnológica de El Salvador. En la edad media y principios del siglo XVI, se conocía el tráfico y venta de esclavos en Sevilla. Lisboa y Sevilla se disputaban el comercio de esclavos, adquiridos en las gradas de la Catedral de Sevilla, cuyo mercado de Cádiz, Sevilla y Lisboa, se disputaban dicho comercio humano por el Atlántico.

Mi investigación sobre la historia de edad moderna, siglo XVI, de El Salvador, me ha permitido encontrar en la memoria histórica de los castellanos que introdujeron los primeros negros africanos en Guatemala, San Salvador y Honduras. En las primeras décadas del siglo XVI, esclavizaron a los indígenas de las comunidades que habían sometido utilizándolos en la explotación minera y búsqueda de oro en las minas y ríos, como en actividades agrícolas. A partir de 1546 se introducen los esclavos negros en la zona de los Izalcos y otros pueblos de Cuscatlán, El puerto de Acajutla, por el comercio del cacao y los comerciantes de Villa de la Trinidad y encomenderos de los pueblos de Izalcos en 1560 introdujeron los primeros negros africanos para realizar trabajos en sus encomiendas.

Palabras claves: Antropología, historia, registro etnográfico, memoria, transmisión intergeneracional, comercio, migraciones, geografía, lingüística.

\section{Abstract}

El Salvador has no modern history due to lack of historical memory. Very little has been written and researched about on the introduction of Africans in Guatemala, El Salvador 
and Honduras. In fact, such topic was addressed by the historians of Universidad Tecnológica de El Salvador. In the middle ages and early sixteenth century, the traffic and sale of slaves was acknowledged in Seville. Lisbon and Seville were disputing the slave trade. Plus, slaves were purchased in the steps of the Cathedral of Seville whose market of Cadiz, Seville and Lisbon disputed this human commerce by the Atlantic.

My research on the modern age, sixteenth century history of El Salvador has allowed me to find in the historical memory of the Castellanos who introduced the first African blacks in Guatemala San Salvador and Honduras. In the first decades of the sixteenth century, they enslaved the natives of the communities to use them in mining and goldmining in both mines and rivers as well as in agricultural activities. 1546 is the starting point where black slaves were introduced in the zone of the Izalcos and others of Cuscatlán, the Port of Acajutla, by the commerce of the cacao and the merchants of Villa Trinidad and encomenderos of the towns of Izalco. In 1560 the first African blacks were incorporated in order to carry out work on their parcels.

Keywords: anthropology, history, ethnographic record, memory, intergenerational transmission, trade, migration, geography, linguistics.

\section{Introducción}

Pedro de Alvarado Adelantado, Capitán General y Gobernador de las provincias de Guatemala, en su expansionismo en Guatemala y El Salvador, llevo los primeros africanos como mano de obra obligada africana, en Chichicastenango y la provincia de de Guatemala y otras comarcas. La necesidad de mano de obra en Indias, activa la búsqueda y capturar de esclavos negros, surgen compañías mercantiles genoveses, castellanos y portugueses. El mediterráneo se activó con este comercio. A principios del Siglo XVI, 1519. 1520 exportaron desde "Arguin hasta las Antillas"1.

\section{Conquista de Cuscatlan. Esclavitud de los indígenas pipiles}

El capitán Pedro de Alvarado, y su hueste, permanecieron dos días en Tacuxcalco. La derrota de este segundo ejército pipil hizo que los pueblos siguientes no presentaran resistencia y los abandonaron. La hueste siguió adelante hasta llegar al hoy desaparecido pueblo de Myaguatlán (Miahuatán), jurisdicción de Caluco, cuyos vecinos se habían ausentado y refugiado en los bosques como lo estaban haciendo la mayoría de la gente. La hueste indiana alcanza el valle de Zapotitán y arriba al pueblo de Atehuan (actual Ateos), donde recibió a los mensajeros de los señores de Cuxcatlán a dar obediencia a los Reyes de Castilla y que querían ser sus vasallos y ser buenos y así se la dieron y él en su nombre los recibió, esperando que no le mentirían como los otros pueblos. La hueste continúa su marcha hasta llegar al pueblo de Cuxnitlán (Cuzcatlán)

\footnotetext{
${ }^{1}$ Véase: Alfonso Franco Silva "la esclavitud en Sevilla sus tierras a fines de la edad media. (C) Universidad Tecnológica de El Salvador 
son recibidos por la comunidad y mientras se acomodaban, la gente abandonó el pueblo y se fueron a las sierras, por los abusos de la hueste. Al ver su actitud, Alvarado envío mensajeros a los señores de allí pidiendo que no pusieran resistencia y que hubieran dado obediencia a la Corona. Ya hemos explicado en qué consistía aceptar el vasallaje. La respuesta de los señores de Cuscatlán fue contundente. No hubo retorno de los mensajeros ni respuesta alguna de los habitantes. Para que el desplante no quedara sin castigo y como ejemplo en el país, envió una expedición de búsqueda y castigo a los montes y sierras en pie de guerra, hubo enfrentamientos de armas, saliendo heridos españoles e indios auxiliares de la hueste sin lograr su objetivo.

\section{Formula de requerimiento}

El capitán Alvarado tomo preso a un indígena principal del Cuscatlán y lo envió a parlamentar con mandamiento e requerimiento, sin importar que los naturales entendieran nada de lo que allí se mandaba o requería. No obtuvo contestación, el Capitán de acuerdo a la fórmula de conquista que justifica la guerra y la toma de esclavos de guerra por infieles y rebeldes. Con el tiempo estipulado abrió proceso a los pipiles de la capital, no sin antes haber comprobado que no poseían el rico metal, el oro. "La obsesión por el oro, que en este caso es el motivo fundamental del viaje de un grupo de hombres armados...",

Como a los otros que le habían dado la guerra, empleo la fórmula de pregones y al no haber respuesta de los señores cerro el proceso y dictó sentencia: declaro traidores y a pena de muerte a los señores principales de Cuscatlán y al resto de la comunidad declarados como esclavos, poniendo el hierro que les identificaba como tal a los capturados y los que se capturan en el futuro hasta que dieran obediencia a la corona. Con el fruto de su venta pagarían once caballos muertos, armas y bastimentos que habían sido empleados en la expedición de conquista al país. La tragedia del pueblo de Cuscatlán inicia su génesis de genocidio, de esclavitud, sobreexplotación y la implantación del sistema esclavista y explorador del español.

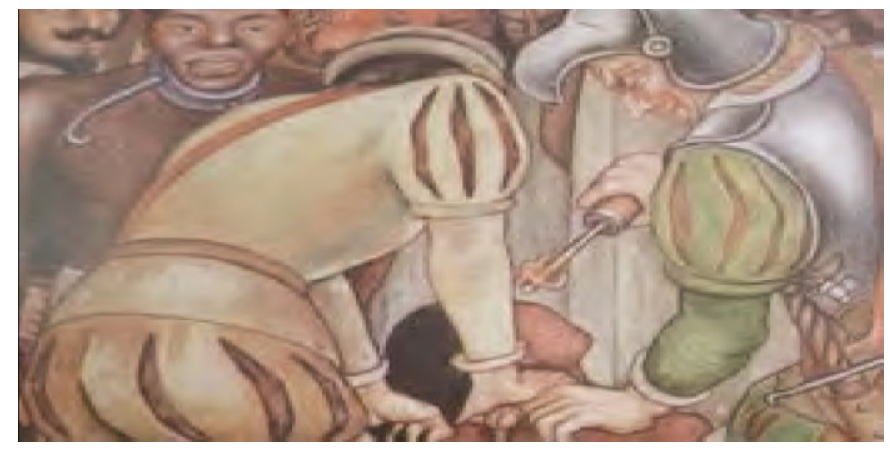

${ }^{2}$ Fuente: Ricardo Piqueras. Encuentros. Debate América Latina Ayer y Hoy. Memoria, creación e historia Luchar contra el Olvido, Universitat de Barcelona, Barcelona, 1994. Pág. 117.

(C) Universidad Tecnológica de El Salvador 
Diecisiete días permaneció en Cuscatlán, enviando expediciones de castigo y mensajeros a otros pueblos como Ilopango, que en el lienzo de Tlaxcala fueron pintadas y narradas por los indios amigos del Adelantado, sin alcanzar su objetivo, la resistencia del pueblo, la espesa vegetación de los montes, la protección de las sierras y el desconocimiento del quebradizo terreno le hicieron desistir en su intento de atraer al pueblo pipil. El indígena de Cuscatlán, para transportar el producto de sus cosechas, empleaba el mecapal, para cargar y transportar sus productos hasta su vivienda. El encomendero español, los utilizo en las actividades agrícolas, como también como animales de carga, para transportar personas, los tributos que les impusieron llevar a las villas y ciudades donde vivían, como al mantenimiento de los esclavos en las minas, cuyas distancias eran excesivas, entre ida y regreso, dejando abandonados a su grupo familiar. La actividad esclavista de los castellanos en Nicaragua y Pedro de Alvarado en Cuscatlán, llevaron gran cantidad de esclavos pipiles y lencas al Perú, el castellano muy dado a poner sobrenombres a sus vecinos, llamaron "guanacos" a los indígenas cuzcatlecos, por comparar sus servicios, docilidad y humildad, con los animales de carga del Perú: llamas y guanacos, costumbre arraigada entre los castellanos de poner apodos a sus vecinos. Término peyorativo muy utilizado en El Salvador, por ignorar su origen y significado. Incluso los intelectuales y escritores del país, lo utilizan.
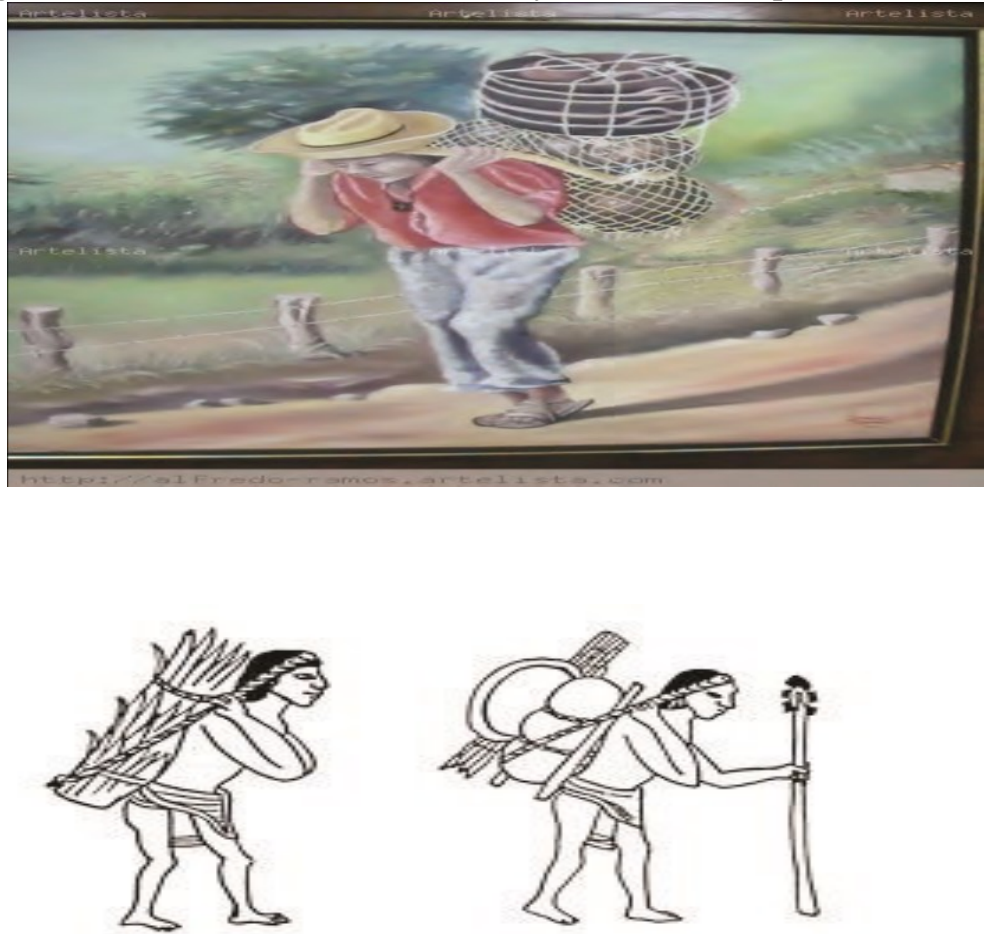

CUniversidad Tecnológica de El Salvador 


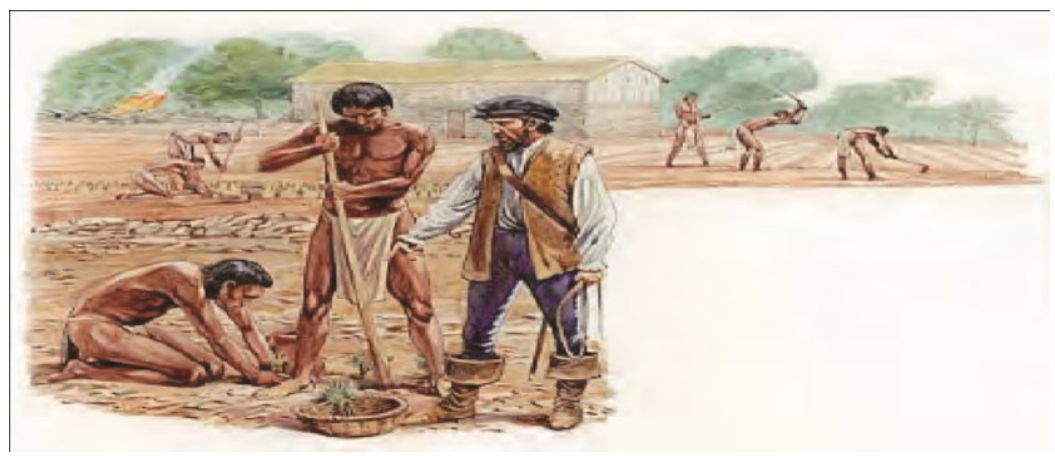

Fuente: tlameme de Naguizalco- Indígenas “Tamemes” Códice Mendoza. Esclavos indígenas en tareas agricolas. historia.blogspot.com. portalguarani.com. educasitios2009.educ.ar.

El adelantado Montejo, El licenciado Maldonado, como Cerrato escribe al Monarca que hay pocos indios en la Gobernación de Honduras y que conviene abrir caminos de Puerto de Caballos a Gracias a Dios, Comayagua y las minas de Olancho. Solicitan mano de obra de esclavos africanos para abrir los caminos en el Puerto de Caballos en Honduras, Atlántico, con el Golfo de Fonseca, Pacífico, en El Salvador, para abrir el comercio del istmo con el Perú y el transporte de la plata y oro expoliado a los países centroamericanos y suramericanos. Esta actividad es el origen de todos los intentos de los castellanos por encontrar la vía de comunicación del Atlántico al Pacífico, todas las ambiciones expansionistas de los conquistadores Pedrarias, Montejo y Castañeda por anexar el territorio de las villas de San Salvador y de San Miguel, por alta densidad demográfica indígena y productos logísticos, que rendirían buenos beneficios. Los diferentes abusos del Licenciado Castañeda que llevó en franca bancarrota la endeble economía de la Provincia y tal como lo habían denunciado los vecinos quejosos de León, la gente emigraba en grandes cantidades hacia el Perú en busca de mejores horizontes. En 1535 ya había abandonado Nicaragua Castañeda marchándose al Perú, aunque dijo que regresaba a España, habiendo dejado delegado al Obispo Álvarez Osorio para que se hiciera cargo de gobernar la Provincia interinamente. Había prometido antes de irse dejar fianza para responder por los cargos desempeñados pero no cumplió con tal obligación.

Llevó 200 vecinos españoles y 900 indios en cinco navíos que tenía con la idea de pasar al Perú (todo esto a pesar de lo pobre que pretendía estar según escrito anterior de Castañeda en su informe a la Audiencia de Santo Domingo del año de 1537), declara que durante su gobierno no se cometieron delitos ni hechos de sangre, no teniendo que castigar a nadie, excepto dos hombres que condenó a la hoguera por pecados contranatura, y algunos blasfemos. 


\section{Justificación}

\section{Contexto del estudio: El Salvador actual.}

Para ubicarnos geográficamente cual es el país de nuestro estudio, es obligado hacer una descripción del país.

Situación geográfica.

a) La situación geográfica de la actual República de El Salvador, tiene una superficie territorial de $21.040 .79 \mathrm{~km} 2$. Limita al norte y este con la República de Honduras; al sur por el Océano Pacífico y al oeste por la

República de Guatemala; sus coordenadas geográficas extremas son: $14^{\circ} 27^{\prime}$ bajón en la bahía de Jiquilisco; $87^{\circ} 41^{\prime}$ ' 08 ' LWG, costa oriental de la isla Meanguerita 00 LN, curso superior del Río Negro, Frío o Brujo en el municipio de Metapán; 13 09' 24 LN, Islote del o , y 90 07’50’ LWG, desembocadura del Río Paz.

b) La Constitución Política de la República de El Salvador de 15 de diciembre de 1983, en su artículo 84 dice:

"El territorio de la República sobre el cual El Salvador ejerce jurisdicción y soberanía es irreductible y además de la parte continental, comprende: El territorio insular, integrado por las islas, islotes y cayos que enumera la Sentencia de la corte de Justicia Centroamericana, pronunciada el 9 de marzo de 1917 y que además le corresponden, conforme a otras fuentes del Derecho Internacional; igualmente, otras islas islotes y cayos que también le corresponden, conforme al derecho internacional.

Las aguas territoriales y en comunidad del Golfo de Fonseca, el cual es una bahía histórica con caracteres de mar cerrado, cuyo régimen está determinado por el derecho internacional y por la sentencia mencionada en el inciso anterior.

El espacio aéreo, el subsuelo y la plataforma continental e insular correspondiente; y además, El Salvador ejerce soberanía y jurisdicción sobre el mar, el subsuelo y el lecho marinos hasta una distancia de 200 millas marinas, contadas desde la línea de más baja marea, todo de conformidad a las regulaciones del derecho internacional."

\footnotetext{
${ }^{3}$ Fuente: La Constitución Política de la República de El Salvador 1983, San Salvador El Salvador C.A. pág.29.

(C) Universidad Tecnológica de El Salvador
} 


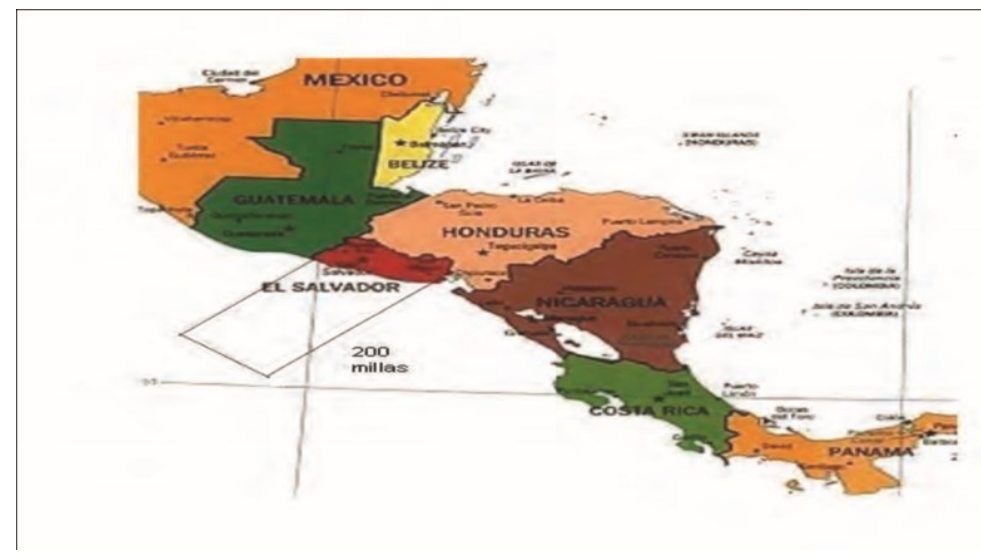

Mapa 1. Mapa 200 millas náuticas El Salvador. Constitución Política de la República de El Salvador de 15 de diciembre de 1983, en su artículo 84.

\section{Origen}

El 15 de diciembre de 1527, con los señores secretario Francisco de los Cobos y doctor Beltrán de la Cueva, hicieron sociedad para exportar 600 esclavos para explotar las minas de Chichicastenango y comarcas de la provincia de de Guatemala, Cádiz, Huelva y Sevilla, tenían una población de negros muy importante. En San Lucar de Barrameda, en 1514 a 1522 tenían "420 esclavos bautizados para una población de 1.000 habitantes.propietarios"4, la iglesia, ciudades andaluzas, cabildos, catedrales, canónigos simples curas y personas de los monasterios y conventos... la nobleza y toda la clase social mercados urbanos andaluces, los reyes de castilla fueron los primeros en autorizar la trata de negros. La influyente familia de la Cueva, Doctor. Beltrán de la Cueva, Duque de Alburquerque, Pedro de la Cueva, Comendador mayor de Alcántara y Alonso de la Cueva apoyan a Pedro de Alvarado, parientes de doña Francisca de la Cueva, contrae nupcias con ella en Castilla. Francisca de la Cueva, falleció al llegar a Veracruz y en 1529. Pedro de Alvarado, procedente de España, acompañado del futuro Obispo de Guatemala, Francisco Marroquín, Francisco de Castellanos, Tesorero, Francisco Zorrilla, Contador y Gonzalo Ronquillo, Veedor, para el Cabildo de Guatemala. Pedro de Alvarado trae plenos poderes sobre su Gobernación. Al llegar a la ciudad de México la audiencia le tenía preparado un juicio de residencia, por su actuación en Guatemala.

\section{7-1530. Contrata Francisco de los Cobos y otros: esclavos para minas}

\footnotetext{
${ }^{4}$ Vease: Antonio Moreno Otero. Luis de Peraza: "historia de Sevilla" (C) Universidad Tecnológica de El Salvador 


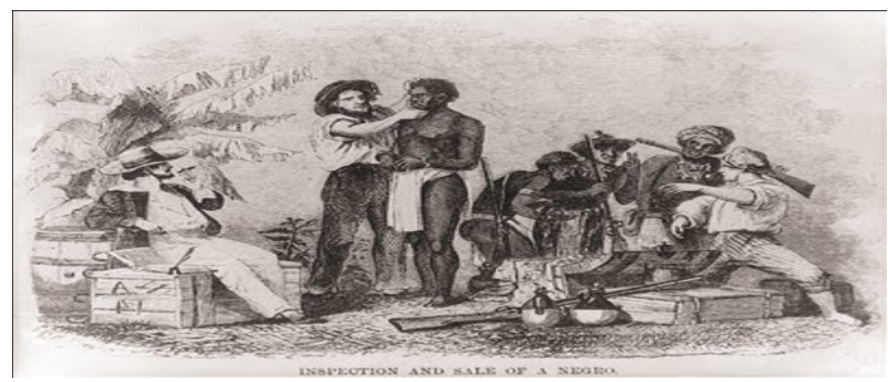

Fuente: Imágenes.cienciassocialesacs.blogspot.com.

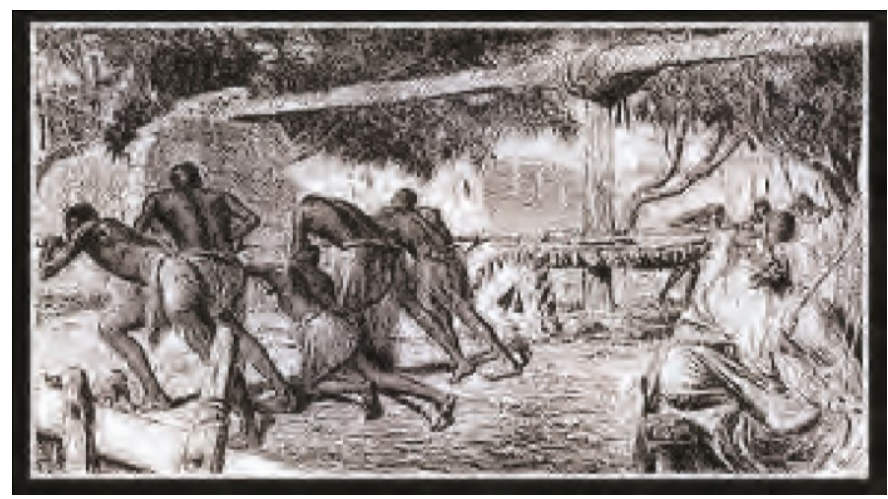

Fuente: sanjuanalmundo.com. embajadadominicana.org

/Fol.1-/ "Sepan cuantos esta carta vieren como yo don Pedro de Alvarado, adelantado, capitán general y gobernador por sus majestades de esta provincias de Guatemala e digo que por cuanto yo hice con los señores secretario Francisco de los Cobos y doctor Beltrán, del consejo de su majestad, cierta compañía y capitulación en la ciudad de Burgos a quince días del mes de diciembre del año pasado de mil e quinientos veinte e siete años, firmado de nuestros nombres en la cual se contiene que yo fuese obligado a poner seiscientos esclavos en las minas de esta provincia e mi gobernación o en otras cualesquier partes para que el oro que sacasen los dichos esclavos lo heredásemos por iguales partes, pagándome primeramente de sus dos terceras partes por cada esclavo, diez pesos de oro, de trescientos maravedies cada un peso, porque a tanto valían los dichos esclavos en aquella parte, en aquellas otras partes, según que esto y como va costar en la dicha carta de compañia se contiene a que me refiere y ahora y ahora yo he venido a esta mi dicha gobernación donde he visto que los dichos esclavos no valen tanto como al ver que hicimos la dicha compañía y porque yo no quiero sino en todo hacer servicio y placer a los dichos señores Francisco de los Cobos y doctor Beltrán, no embargante que sus mercedes eran obligados a me pagar los dichos diez pesos de oro, por todos los esclavos que les cupiesen de sus dos tercias partes

(C)Universidad Tecnológica de El Salvador

REVISTA DE MUSEOLOGÍA KÓOT, 2017 AÑO 7, n. ํ 8, ISSN 2078-0664, ISSNE 2378-0664 

Salvador y Honduras. Págs. 82-172.

DOI: http://dx.doi.org/10.5377/koot.v0i8.5872

URI: http://hdl.handle.net/11298/386

e que viendo así mismo la mucha costa que hay que mantener los dichos esclavos en las minas y lo mucho que valen en estas partes las herramientas y otras cosas que son menester para sacar el dicho oro y si todo esto me hubiesen de pagar les seria mucha costa, pero como deseo y voluntad y dicha tengo afirmando y heredando como afirme y heredo la dicha compañía e cobro en lo que dice de los diez pesos por cada esclavos que así me lo han obligado a dar e pagar, no esmero a que me den más de tres pesos de oro de minas por cada uno de los dichos esclavos que asi les cupiere de los dos sus dos tercias partes e que para alguna ayuda de esta quiebra que asi les hago, sean así obligados los dichos señores secretario Francisco de los Cobos y doctor Beltrán, a me dar e pagarme las dos tercias partes de todas las herramientas que se gastan en coger el dicho oro, todo el tiempo que tuviésemos la dicha compañía, lo cual se me pague en las fundiciones que se hiciese en estas partes, porque yo pueda tener aparejo de traer las dichas cuadrillas y esclavos proveidos de todas las herramientas que fueren menester y digo a esta dicha costa de herramientas, será a vista de la así vivan como personas que tienen parte los dichos señores secretario Francisco de los Cobos y doctor Beltrán, del cual y al cual estoy listo y aparejado de recibir y lo así me pudiera dar y acudir con lo que hubiese sacar $y$ adquirir con los dichos esclavos y desde ahora nombro y señalo en cumplimiento de los dichos seiscientos esclavos, una cuadrilla de cien esclavos con todo el aparejo de herramientas y aderezo que para coger el dicho oro es /Fol.2/ menester andan este pueblo de Chichicastenango para que gocen de ella, no es bastante que no me haya sido acabado de pagar lo que de sus dos tercios, pues les cabe del dicho del otorgamiento de esta causa en adelante y que de hoy en hechos primos sin que yo terne otra cuadrilla de otros cien esclavos, hecha con todo sus aparejos coger oro y pagándome de ellos lo que les compre de las dichas dos tercias partes a respecto de los dichos diez pesos de oro, desde este puedan gozar e gocen de los que viniere sueldo a libra y si toda la cantidad no me fuese pagada al dicho respecto como me fuese pagado, valla gozando de lo procedido de los dichos esclavos como y del a manera que se contiene en la otra carta de compañía y así ser yo obligado de ir cumpliendo el dicho número de los seiscientos esclavos por manera que la dicha compañía haya que consiga entero efecto y poder que lo que dicho tengo sin lo de lo consultar con los dichos señores secretario Francisco de los Cobos y doctor Beltrán y así lo he concertado con el dicho Luis de Vivar en su nombre y tengo creído que puede servir como les sirvo esto lo habrán por bueno y pasar por ello yo me obligo como y de la manera como estoy obligado en la otra compañía y concierto entre sus mercedes y mi está hecho que estrujé y pasare por lo aquí contenido hasta ahora y para siempre jamás, so pena que les pague todas las costas y demás intereses e menos cabos que se les renegaren en cualquier manera por así no lo haredes y cumplir y visto los dichos señores secretario Francisco de los Cobos y doctor Beltrán, no tuvieron por bien dicho que cumpliere por la otra dicha carta de compañía estoy obligado a que no sea visto yo por esta escritura,

(C) Universidad Tecnológica de El Salvador 
derrocar cosa alguna de la otra carta, cuando sino que deba estar por ello y se fuesen contentos y servidos de lo que aqui contenido que lo mantendré y cumpliré como es dicho y declarado en testimonio de lo cual otorgue la presente ante el escribano y testigos infrascritos y lo firmo de su nombre este registro de esta carta. Fecha esta en la ciudad de Santiago de Guatemala a veinte e cuatro días del mes de julio año del nacimiento de nuestro salvador Jesucristo de mil e quinientos e treinta años. Testigos que fueron presentes a lo que dicho es Antonio Dios dado e Pedro de Villareal. El adelantado Pedro de Alvarado. Yo Juan Páez escribano público y de cabildo de esta ciudad de Santiago presente fui a dicho otorgamiento del pedimento del dicho señor adelantado esta carta así vinieren de paz. Aqui mi signo //signio// en testimonio de verdad. Juan Páez. Escribano público y de cabildo.",5

Pedro de Alvarado y sus hermanos eran hijosdalgo, sector secundario de la nobleza de la península castellana del escalón de la pirámide del poder del siglo XVI, su ascenso en la nobleza castellana, se debio a su experiencia militar y su expansionismo conquistador en tierras caribeñas: isla de Cuba, donde fue encomendero de indios, en la conquista de Méjico, fue protagonista con Cortes, en 1519, continuo su expansionismo en 1524 a conquistar el reino de Guatemala y Cuzcatlán, su experiencia militar le permitió su ascenso al círculo de personas importantes de la corona, en la Península. En la Corte castellana, logra hacer amistad con Francisco de los Cobos, secretario de Estado del Emperador Carlos V, muy importante en la Corte, y el doctor Beltrán de la Cueva, Duque de Alburquerque, miembros del Consejo del Rey, el dia 18 de diciembre se le da el nombramiento de Gobernador y Adelantado de Guatemala, con el sueldo anual de 562.500 maravedíes.

\section{Dada en Burgos el 18 de diciembre de 1527: Real Cédula de nombramiento de Gobernador y Capitán General de Guatemala a favor del Adelantado Pedro de Alvarado}

"SEPAN cuantos esa carta de poder vieren, como yo el Adelantado don Pedro de Alvarado, Gobernador y capitán General de Guatemala y sus provincias digo que por cuanto su majestad por una provisión me hizo merced de los dichos cargos según más largamente en la provisión que de ello se mandó dar se contiene, el tenor de la cual es este que se sigue:

Don Carlos por la gracia de Dios, Rey de romanos, Emperador Semper Agusto e Doña su Madre y el mismo don Carlos por la misma gracia, reyes de Castilla e de León, de Aragón, de las dos Sicilias, de Jerusalén, de Navarra, de Granada, de Toledo, de Valencia, de Galicia, de Mallorca, de Sevilla, de Cerdeña, de

${ }^{5}$ Fuente: Trata Francisco de los Cobos y otros: Esclavos para minas Archivo General de Indias, PATRONATO,246,N.2,R.14 - 4 - Imagen Núm: 4 /AGI. Patronato 246.N² 2. R.13.

(C) Universidad Tecnológica de El Salvador 

Salvador y Honduras. Págs. 82-172.

DOI: http://dx.doi.org/10.5377/koot.v0i8.5872

URI: http://hdl.handle.net/11298/386

Córdoba, de Córcega, de Murcia, de Jaén, de los Algarbes, de Algeciras, de Gibralar, de las islas Canarias, y de las Indias, islas y tierra firme de la mar océano; Condes de Barcerlona, Señor de Vizcaya y de Molina, Duques de Atenas y Neopatria, Condes de Ruysellón y de Cerdaña, Marqués de Oristan e de Borgoña, Archiduque de Austria, Duque de Borgoña e de Bramante, Conde de Flandes y de Tirol, etc., por cuanto nos somos certificados de los muchos y buenos y leales servicios que vos el capitán Pedro de Alvarado nos habéis hecho en la conquista e pacificación de las nuevas provincias, especialmente, en la provincia que se dice de Guatemala porque entendemos que así cumple a nuestro servicio a la buena gobernación de esas tierras y administración de la nuestra justicia en ellas, es nuestra merced y voluntad, que ahora de aquí adelante cuando nuestra voluntad fuere, vos el dicho Pedro de Alvarado, seais nuestro Gobernador y Capitán General de la dicha tierra e provincias de Guatemala, que son la ciudad de Guatemala que se dice ahora Santiago con la tierra de Yucatán y Sinacatán y Tequepan Puyumatllán y de Cicalá y de Cuistepeque, con lo a ellas anexo e pertenecientes con tanto que en todas las cosas, asi de gobernación como de justicia, vos he dicho Pedro de Alvarado y vuestros oficiales y lugartenientes seáis sujetos a la nuestra Audiencia y Chancillería real que a de residir en la gran ciudad de Tenustitán, México, que de vos y de vuestros oficiales e lugartenientes se pueda y haya de apelar apele en todas las causas civiles y criminales para ante los nuestros Presidente y oidores que en la dicha ciudad residen y seáis obligado de otorgar las tales apelaciones en los casos que de derecho hubiere lugar, pero en las causas civiles en la condenación y absolución de ellas si fuere de cuarenta mil maravedies, abajo, queremos e mandamos que las apelaciones que se interpusieren vayan a este la justicia y regidores del ayuntamiento de la ciudad, villa y lugar de donde fuere la dicha causa y mandamos que podáis usar y uséis de los dichos oficios de nuestro gobernador y Capitán General de las dichas tierras por vos y por los dichos vuestros lugartenientes, los cuales podáis quitar e admover cada y cuando que quisieredes que a nuestro servicio y a la ejecución de la nuestra justicia y paz y sosiego de la tierra convenga y para hacer y cumplir lo suso dicho por esta nuestra carta damos poder cumplido por la cual o por su traslado signado de escribano público mandamos a los concejos, justicias y regidores, caballeros, escuderos, oficiales y hombres buenos de todas las ciudades, villas y lugares de las dichas tierras e otras cualquier partes personas de cualquier estado y condición que sean o ser puedan que en las dichas tierras estén o estuvieren y a ellas fueren, que os hayan y tengan por nuestro Gobernador y Capitán General de ellas y vos dejen y consientan usar de los dichos oficios y ejecutar la nuestra justicia por vos y por los dichos lugartenientes no otra persona ni personas algunas y como tal nuestro Gobernador podáis oír y librar y determinar oyáis y libréis y determinéis todos los pleitos y causas, así civiles como criminales, que en las dichas tierras e provincias estuvieren comenzadas movidos se comenzaren e

CUniversidad Tecnológica de El Salvador

REVISTA DE MUSEOLOGÍA KÓOT, 2017 AÑO 7, n. ${ }^{\circ}$ 8, ISSN 2078-0664, ISSNE 2378-0664 

Salvador y Honduras. Págs. 82-172.

DOI: http://dx.doi.org/10.5377/koot.v0i8.5872

URI: http://hdl.handle.net/11298/386

movieren adelante y podáis y podáis llevar y llevéis vos los dichos vuestros lugartenientes los derechos y otras cosas al dicho oficio de nuestro Gobernador y Capitán anexas pertenecientes y podáis hace ordenanzas generales en toda vuestra gobernación y particular en cada pueblo que sean útiles y provechosas a la dicha tierra y vecinos de ella, por donde se rijan y gobiernen los vecinos de ella, para que vivan como buenos cristianos en toda paz y sosiego y se aparten de las malas costumbres y vicios que comúnmente tienen las otras gentes donde están y se hacen y por las otras personas nuevos pareciere que deben ser puestas para que las guarden y ejecuten en ellos, si las quebrantaran y vos y los dichos vuestros lugartenientes podáis hacer y hagáis cualquier pesquizas en los casos de derecho, premisas y todas las otras cosas al oficio anexas e convenientes de la nuestra justicia cumpla y que para usar y ejercer el dicho oficio de nuestro Gobernador y Capitán General y cumplir ejecutar la nuestra justicia todos se conforme con vos el dicho Pedro de Alvarado y con los dichos vuestros lugartenientes y como a tal os acaten y obedezcan a vos y no a otra persona y capitanes y gente de cualquier calidad y condición que sea, que en la dicha tierra estuvieren y a ellas fueren que así lo cumplan sin poner en ello escusa ni dilación alguna sin interponer de ello apelación ni suplicación so las penas que vos de nuestra parte les pusieredes y mandaredes poner las cuales nos por la presente le ponemos e habernos por puestas e a vos damos poder y facultad para las ejecutar en los que rebeldes $e$ inobedientez fueran y que vos den y hagan dar todo el favor y ayuda que les pidieredes y menester hubieredes y que y que pongan ni consientan poneros, por la presente vos recibimos y habemos por recibido al dicho oficio, al uso y ejercicio de él y vos damos poder y facultad para lo usar y ejercer con todas sus incidencias e dependencias, emergencias, anexidades e conexidades otros si vos mandamos e las penas pertenecientes a la nuestra cámara y fisco, así las que hallaredes condenadas en la dicha tierra y provincia de Guatemala, como las que vos y los dichos vuestros lugartenientes condenaredes y pusieredes, las ejecutéis y hagáis ejecutar y dar y entregar a nuestro Tesorero de la dicha tierra o a quien su poder hubiere y por esta nuestra carta mandamos a cualquier persona o personas que tiene o tuvieren las varas de nuestra justicia, alcaldía o alguacilazgo de la dicha tierra y provincias de Guatemala, que desde luego que por vos el dicho Pedro de Alvarado fueren requeridos a vos lo den y entreguen e no usen de ellas más sin nuesra licencia y especial mandado, so las penas en que caen incurren las personas privadas que usan de oficios para que no tienen poder ni facultad, que nos por la presente los suspendemos e habemos por suspendidas otro sí es nuestra merced y voluntad que si vos el dicho Pedro de Alvarado entendéis ser cumplidor a nuestro servicio e a la ejecución de nuestra justicia que cualquiera caballeros otras personas lo que ahora están o estuvieren en la dicha tierra, salgan de ella y no entren ni estén más en ella que se vengan a presentar ante nos a los cuales todos por la presente a quien vos lo mandaredes, mandamos que luego sin sobre ello vos

(C) Universidad Tecnológica de El Salvador

REVISTA DE MUSEOLOGÍA KÓOT, 2017 AÑO 7, n. ํ 8, ISSN 2078-0664, ISSNE 2378-0664 

Salvador y Honduras. Págs. 82-172.

DOI: http://dx.doi.org/10.5377/koot.v0i8.5872

URI: http://hdl.handle.net/11298/386

más requerir ni consultar, ni esperar otro nuestro mandamiento, segundas o terceras succión y sin interponer de ello apelación ni suplicación, lo pongan en obra según nuevos digieredes e mandaredes, so las penas que vos de nuestra parte pusieredes e mandaredes poner, las cuales nos por la presente les ponemos y habemos por puestas vos damos poder y facultad para las ejecutar en los que remisos e inobedientes fueren y es nuestra merced y mandamos que hayais y llevéis de salario ayuda de costa en dada un año con el dicho oficio de nuestro gobernador y Capitán General, quinientos y sesenta y dos mil y quinientos maravedis, los cuales vos sean dados e pagados de las rentas y provechos nuestros que tuvieremos en la dicha tierra por nuestro tesorero de ella, por los tercios cada año, según y cómo se pagan los otros salarios de los otros nuestros oficiales de la dicha tierra e que tomen en cada un año con la cual y con el traslado signado de nuestra provisión, mandamos que le sean recibidos y pasados en cuenta las dichas quinientas sesena y dos mil y quinienos maravedis, de los cuales goséis y os sean dados y pagados desde el día que vos hiciéredes a la vela en el Puerto de San Lucar para seguir vuestro viaje en adelante todo el tiempo que tuviéredes y sirvieredes el dicho cargo, siendo tomada la razón de esta carta por los nuestros oficiales e residen la ciudad de Sevilla, en la casa de Contratación de las Indias y los unos ni los otros no hagáis ni hagan en deal por alguna manera, so pena de las nuestra merced de diez mil maravedies para la nuestra cámara e cada uno que lo contrario hiciere. Dada en Burgos a diez ocho del mes de diciembre, año del nacimiento de nuestro señor Jesucristo de mil y quinientos y veinte y siete años. Yo el Rey y Francisco de los Cobos, secretario de sus cesarias y catolicas majestades, la hice escribir por su mandado. Fratis Garciepis Coposojomalis. El Doctor Beltrán, registrada Juan de Samano, Martín de Urbina por Chanciller. Asentose está provisión de su majestad en los libros de la Casa de Contratación, Adelantado y Gobernador don Pedro de Alvarado por su majestad en el cabildo de esta ciudad de Santiago, ante mí Antón de Morales, escribano que fue ocurdecida y recibido el dicho señor teniente de Gobernador suso dicho y admitido al cargo según y cómo en ello se contiene de nueve días del mes de mayo de mil quinientos y veinte y nueve años, Antón de Morales, escribano..." 6

\section{Pedrarias Davila y el tràfico de esclavos. 1527-1536}

"Lo ocurrido en la futura Nicaragua sintetiza de alguna manera el carácter de la agresión. David R. Radell (1976, 67-76) pormenorizó el tráfico de esclavos, principal actividad económica durante el segundo cuarto del siglo 16: la mercancía humana era vendida en Panamá, Perú o Antillas; unos 448000 aborígenes habrían sido exportados

${ }^{6}$ Fuente: AGI.AG.Leg.10. Real Cédula de nombramiento de Gobernador y Capitán General de Guatemala a favor del Adelantado Pedro de Alvarado. Dada en Burgos el 18 de diciembre de 1527. 451-266 (C) Universidad Tecnológica de El Salvador 
entre 1527 y 1536 y entre la primera fecha y 1548, 500000 fallecieron víctimas de la guerra y las epidemias, o consiguieron huir hacia el este." Radell resume su pesquisa: de 1523 a 1583 la población, vinculada a una cultura espectacular, a juzgar por los restos arqueológicos, habría caído de 1.000 .000 a 10.000 personas, quedó reducida al 1\%. La descripción de esta violenta agresión resulta paradigmática. El sadismo de Pedrarias es de sobras conocido a pesar de los esfuerzos de la LAI por enmascararlo. "'

Segundo viaje a la Península, su protector Francisco de los Cobos casa a Alvarado con Beatriz de la Cueva, hermana de la fallecida Francisca, con licencia de la Iglesia romana, las dos hermanas eran sobrinas nietas del primer duque de Alburquerque y su parentesco con Alvarado, facilito el viaje a Guatemala con los privilegios castellanos de la familia a Francisco de la Cueva, paje de Carlos V. y primer factor de Guatemala y Juan de Mendoza, nombrado capitán en la conquista de Choluteca, de la Cueva y Luis Dubois fueron los dos únicos caballeros gentiles hombres pagados y reconocidos por la Corona en la provincia de Guatemala y San Salvador.

\section{Tercer viaje de Alvarado a la Península}

Respecto a la residencia, escribió Alvarado que llegó el oidor Licenciado Maldonado a tomar residencia a él y sus oficiales y que le acusan que cuando partió al Perú había hecho mucho daño a los indígenas y vecinos de su gobernación. Se pregonó su residencia en forma con término de cincuenta días, se le mando no salir de la ciudad y no hubo persona que le pusiera demanda civil y criminal, ni que dijese tenía queja de él, ni halló cosa alguna para hacer información contra él. Así el oidor se volvió a la ciudad de México sin hacer cosa ninguna. La intención de su presencia fue debida hacerle mala obra.

20 Noviembre de 1536, Carta escrita por el Adelantado Pedro de Alvarado, dirigida a su majestad haciendo relación a su carta de fecha 12 de mayo sobre la comisión para que buscase puerto en la mar del norte e información sobre descubrimiento de un puerto en la boca del río Lempa, donde se ha poblado una villa que llaman de San Miguel, solicitud de licencia para ir a España.

\section{"MUY ILUSTRE Y REVENDERISIMO SEÑOR Y MAGNIFICOS}

SEÑORES -A doce de mayo de este año, escribí a vuestras señorías y mercedes, dándoles cuenta de lo que me sucedió en la tierra del Perú, a donde aporte con mi armada y de venida a esta gobernación y ciudad de Guatemala, y el estado en que hallé las cosas de esta provincia, y como por cosas que cumplan al bien de ella y al

\footnotetext{
${ }^{7}$ Fuente: Miquel Izard. Encuentros. Debate América Latina Ayer y Hoy. Conquista y resistencia en la historia de América .Universitat de Barcelona, Barcelona, 1992. Pág.455-456.

CUniversidad Tecnológica de El Salvador 

Salvador y Honduras. Págs. 82-172.

DOI: http://dx.doi.org/10.5377/koot.v0i8.5872

URI: http://hdl.handle.net/11298/386

servicio de su majestad, no podía ir luego a besar sus reales manos como lo traía pensado hacer.

Y asimismo, enviaba a suplicar a su Majestad, me enviase licencia para que después de acabado lo que aqui había de hacer, yo fuese a esos reinos para desde ellos salir con una armada y la gente necesaria a ella, para venir por el estrecho de Magallanes a la otra costa del especiería y poblar en él alguna parte de ella o en alguna isla, para desde alli descubrir todo lo que hubiese por la mar del sur, porque yo creía que de esta manera y con la ayuda que de estas partes podía ir a donde primero se poblase y se descubriría y conquistaría todo lo de aquella mar y también de si a el socorro que en esta costa yo traía de navios y gente y caballos y bastimentos y jarcia y que no sostenía hasta setenta mil ducados de lo que traje del Perú, de lo que me dieron por mis navios y otras cosas para los gastos en las naos y gente y aderezos que yo hiciese en Castilla para hacer esta jornada, como ya su Majestad lo habrá visto por mis cartas y vuestras señorias y mercedes.

Después acá se ofrece que aqui ha sabido la partida de su Majestad de esos reynos, para la conquista de allende y Levante y los grandes gastos y armada y gente que lleva y como conviene para tan gran empresa que pliegue a vuestro señor le dé victoria, pues la obra y se lo es tan Santo y pareció me que ocupado su Majestad en cosas tan grandes se tardaría mucho en venir la licencia para mi camino, juntamente con los otros despachos que yo enviaba a pedir, y también que ir a una jornada tan larga y donde era menester, gente que según la mucha que su majestad debe llevar en su servicio, sería dificultoso de sacarla de esos reinos, especialmente para tan largo viaje, y a cosa tan incierta, cuanto parecería y lo que ellos tienen poca noticia y juntos con estos, que en llegando yo a esta Gobernación, vino a ella un oidor de los de la audiencia Real que reside en México, despachado por el Presidente y Oidores de ella a me tomar residencia a mí y a mis oficiales y a desagraviar a los que o tuviese agraviados y con la nueva su venida todos aquellos a quien yo debía dineros por obligaciones y escrituras de las deudas que hice para el despacho de la armada, me amenazaban de arte sobre la cobranza que viendo que no podía venir a tiempo la cédula que a su Majestad envié a pedir, de suspensión de mis deudas, y por no pagarlos con costas, pagué a todos, antes de tiempo, para que el oidor tuviese menos que hacer.

Además de esto sobre todas la malas obras y agravios que yo recibi del Adelantado Pizarro, del Mariscal Almagro, de que tengo hecha larga relación a su Majestad, recibí un muy grande engaño, que todo la paga que se me hizo de mis navios y otras cosas fue en planchas de plata que 


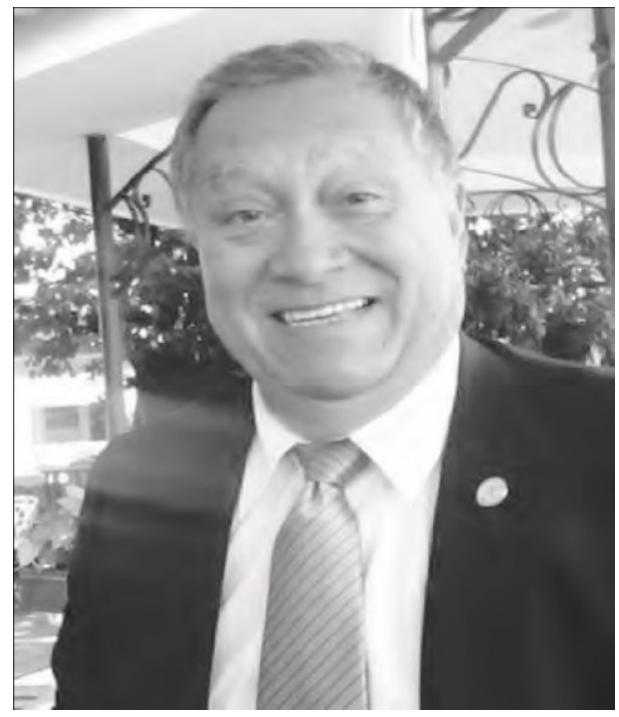

Sigfredo Cabrera Rajo

hicieron de joyas y vajillas del Perú y al tiempo que las fundían para hacer las planchas revolvieron con ellas tanto cobre en pedazos, que donde pensé que traía plata era la más parte cobre, por manera que yo perdí por este engaño casi la mitad de lo que pensé que traía.

Todo esto se juntó para estorbarme de no poder sostener los LXXU ducados que a su majestad escribi con que había de hacer el armada en estos reynos, aunque si yo creyera que hubiera efecto con hallar gente y con la brevedad venida de los despachos, aunque vendiera cuanto tengo y lo de mis amigos y deudos, me dispusiera a hacer el viaje y como tengo por cierto los inconvenientes que digo a me a parecido que perder tiempo, pues todo lo que yo estuviere sin que ocuparme en algo en que sirva a su Majestad, lo que tengo muy mal gastado, especialmente dándonos su majestad en ejemplo el que no da en ponerse a tantos trabajos y peligros de guerra, que no es razón que sus vasallos huelgen sino que gasten lo que tienen y ocupen sus personas en su real servicio y busquen de donde se puede sostener eso otros, como yo lo hago, pues y comprando dos navios de razonable porte y un bergantín grande, los cuales están ya hechos y en el agua, para los enviar por esta mar del sur a descubrir por ellas, lagunas islas o tierra donde su Magestad sea servido y su patrimonio real acrecentado, en los cuales envío por Capitán de ellos a Francisco Castellano, Tesorero de su Magestad y bien proveídos de gente de mar y tierra y oficiales y bastimentos y armas y más munición y tiros que yo he podido hacer, todo para un año, con las derrotas y navegaciones que me han parecido 


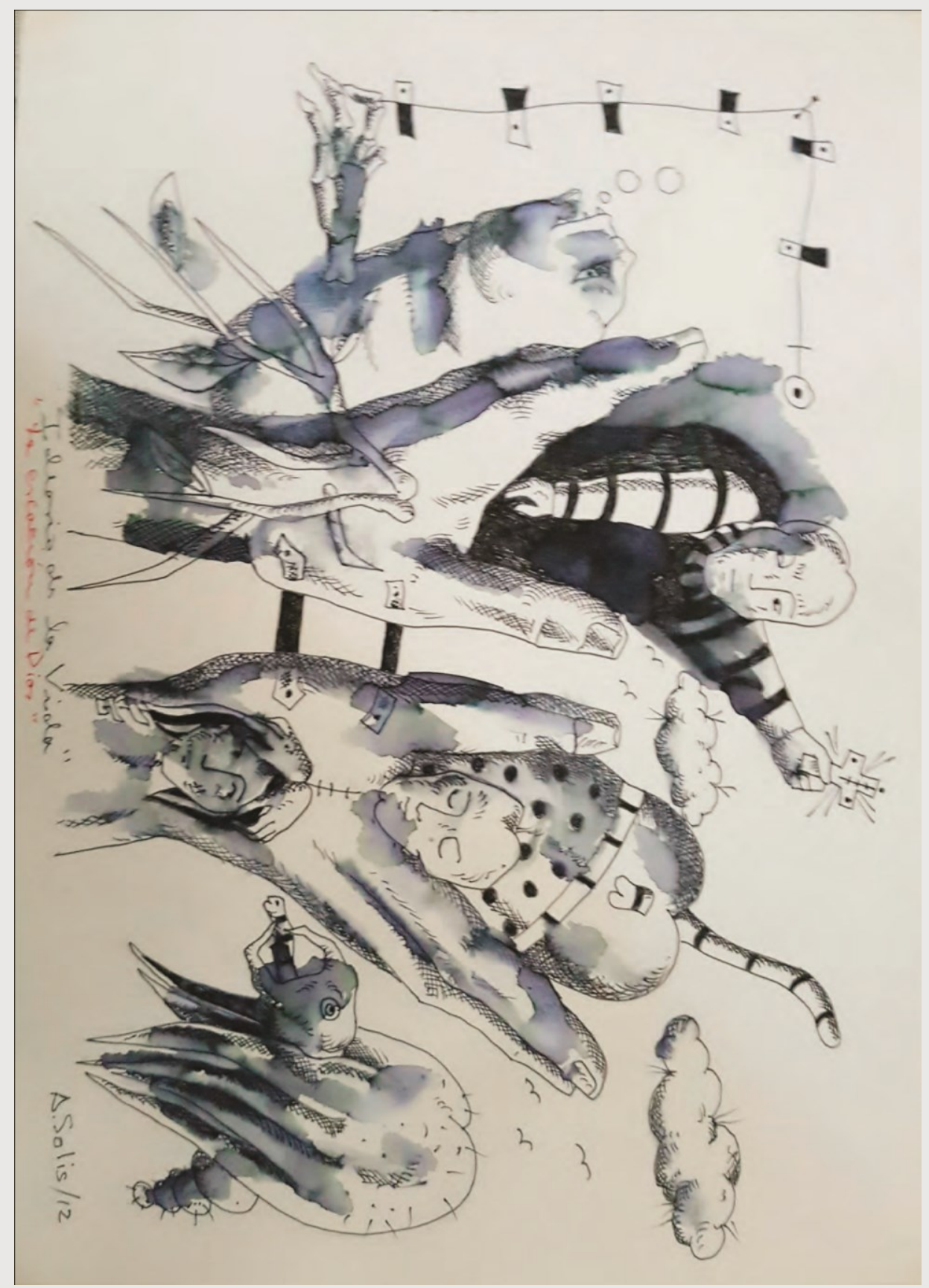

Armando Solis 
que deben llevar a un Gines de Mafla por piloto mayor, que es uno de los mayores hombres de esta mar del sur que ahora se sabe, porque fue con Magallanes y ha hecho otros viajes por ella y se hará a la vela en todo el mes de enero primero que viene, porque todo lo necesaria para ello está muy a punto y además de esto comienzo a poner en astillero tres galeones de cada cien toneles de porte y una galera todo de remos que estarán hechos y a punto antes del término del año que doy de demora a estos tres navios para los cuales yo funde aqui artillería de fusilera y procuraré que lleven tanta y de ella tanta munición y tan bien proveídos y emplomados y pertrechados que puedan andar toda esta mar del sur sin tener temor a ningún armada de Portugal ni a otra naos que anden en ellas y con ser navios de remos podrán entrar y salir donde quisieren sin que las corrientes ni vientos contrarios se lo estorben pues esto de las corrientes a sido parte que se hallaren para ver los tiempos que corren, bien dentro en esta mar de donde quede aviso de la manera y porque tiempo es buena la navegación por ella. Y para la provisión de ellos yo tengo ya comprados el hierro y jarcia y municiones y otras cosas que es necesario y tengo mucha gente de mar y oficiales de carpinteros y calafates y mucha gente de tierra, porque aunque para otros efectos no se hiciera esta armada, sino para ocuparla en algo, se hiciera a su majestad mucho servicio y cuando ellos estén a punto de navegar será nuestro señor servido que estos otros navios traigan nuevas de algunas islas pobladas y tierras que vamos a conquistar de que su Majestad sea muy servido y su patrimonio real acrecentado, pues este es siempre mi deseo y cuando estos navios hayan de partir pienso partir con ellos en persona o enviarlos tan a buen recaudo que yo quede satisfecho y daré siempre aviso a su Majestad y a vuestras señorías reverendísimas y mercedes de lo que todo esto sucedieres y si a su Majestad fuere servido que con ellos se vaya a alguna parte cierta por estar de que en esos reinos se tenga noticia, enviándolo su Majestad a mandar a vuestras señorías y mercedes se hará.

Y pues yo en esto pongo y he gastado cuanto tengo y he podido haber cómo se podrán informar del que la presente lleva, y mi deseo es siempre enderezado a servir a su Majestad, justo es que vuestra señoría y mercedes me favorezcan, para el buen despacho de ellos, y manden despachar una cédula de su Majestad, en que haya por bien la ida del dicho Tesorero y de las demás vecinos de esta Provincia que quisieren de su voluntad ir a servir a su Majestad en esta armada y que el provecho que del suceso hubiere sea en proseguimiento de lo que son su Majestad yo tengo capitulado acerca del descubrimiento de la mar del Sur, pues también para este efecto y la despacho y pues estos viajes son inciertos y yo he gastado cuanto tengo y tengo de gastar en esta empresa, vuestras señorías reverendísimas y mercedes, favorezcan para sostenerme en esta gobernación de esta Provincia, pues yo he dado siempre buenas cuentas de ella, como su Magestad o vuestras señorías y mercedes serán informados, porque tengo con que reacerme para 
tornar a servir, que según el deseo yo tengo y lo que he servido y espero servir, bien merecí que se me haga toda merced. Y a vuestras señorías y mercedes suplico que no permitan que a ella vengan juez ninguno ni quien tenga mando sobre mí, provea cosa ninguna, hasta que estos navios sean acabados y hayan salido, pues cualquier estorbo que para esto se pusiese, sería dar conmigo y con ellos el travez y yo quedarme con lo gastado y su Majestad sin ningún servicio ni provecho, que yo espero de este viaje, pues irá también enderezado y se descubrirá cosa por donde su Majestad sea señor de todo estar Mar, que son ser los navíos de remos, se podrá saber los secretos de ella.

Ya digo a Vuestra Señorías reverendísimas, el modo como vino aquí un oidor de la Audiencia Real de México que se llama el Licenciado Maldonado, a me tomar residencia con relación que había muchos agravios por mi y por mis oficiales y que al tiempo que yo partí con el armada pasada, había hecho muchos daños a los naturales y vecinos de esta gobernación. Él se pregonó su residencia en forma, con término de cincuenta dias, los cuales yo recibi en esta ciudad, sin salir de ella y no hubo persona que me pusiese demanda civil ni criminal, ni que dijese que tenía queja de mí, como constan por el testimonio del mismo escribano que trajo, que envió a ese Real Consejo, ni tampoco halló cosa ninguna de que hacer información contra mí y así él se volvió a la ciudad de México sin hacer cosa ninguna. La intención de su venida, debiera ser pensando hacerme mala obra, así como mi deseo siempre ha sido bueno servir a su Majestad y de procurar hacer lo que debo. Me ha salido bien, porque bien sé que a Vuestra Majestad y a vuestras señorías y mercedes se hizo relación que al tiempo de mi partida con el Armada, yo saqué mucha gente de los vecinos y naturales de esta gobernación y que quedo despoblada y que había hecho otros agravios a su Majestad y a vuestras señorías y mercedes verán, como si la hubiera hecho verdadera relación, hubiera quien lo pidiera y me siguiera viniendo a hacer justicia un oidor tan preeminente. Y así suplico a vuestras señorías y mercedes que cuando de alguna cosa les informase contra mí, sea yo primero oído, antes que se provea contra mí, porque quien siempre procura el servicio de su Majestad y pone el trabajo e intereses de su casa, no lo perderá por otra parte, que yo daré tal descargo de lo que contra míse dijere, que aquello que se me tuviere a mal parezca claro, que es el contrario y que es para mejor servir a su Majestad, sin daño de tercero ninguno, de donde podrá ver su Majestad e vuestra señorías y mercedes, si en sostenerme en esta gobernación a alguno que ello se agravie, y los naturales están pacíficos y la tienen prospera y todos asi conformidad para hacer las cosas del servicio de su Majestad.

A mi se me envió una provisión de su Majestad para que yo fuese en persona a buscar algún Puerto a la mar del Norte, cerca de esta gobernación y poblase en el una villa a donde pudiesen venir loa navios que de esos reynos vinieren a esta provincia, la Emperatriz nuestra señora, me mandó por una su carta que no me entrometiese en lo que toca a cosas ninguna de la tierra 
de Naco e de Honduras, por cuanto había proveído de aquella gobernación A Diego de Albitel y por otra parte el Adelantado Montejo, viene a poblar la tierra de Cozumel y en estas dos gobernaciones se encierra toda la costa de la Mar del Norte que confina con esta gobernación, por manera que yo no puedo entender en lo que su Majestad anda, sin entrar en los límites de estas dos gobernaciones, aunque bien veo que ninguno de estos gobernadores tiene posibilidad ni manera para calar toda la dicha costa, para buscar puerto ni poblarla, pero si todavía su majestad fuere servido y vuestras señorías y mercedes les pareciere que se haga y me lo quisieren cometer mándenme enviar las provisiones necesarias para ello y especialmente para que yo pueda sacar indios de guerra de los naturales de esta gobernación y provincia para la conquista de aquella costa. Yo buscaré si hubiese puerto y siendo de tal disposición que convenga poblar y que se puedan sostener vecinos españoles, yo poblare una villa y haciéndose se hará una de las cosas más provechosas que en estas partes se haya hecho, por la breve navegación que hay desde las Islas españolas y Fernandina y otras islas a esta costa del Norte y de ella a la de la mar del Sur a donde se ha descubierto un muy buen puerto hondable y seguro en la boca del río de Lempa, donde se ha poblado una villa que se llama de San Miguel, donde se podrán proveer todos los navios que allí aportaren y se puede dar carena y cargar y de esta manera se comunicará con poco trabajo la mar del norte, con la del Sur y será gran provecho para si se descubriese algo por ella.

Ya que su Majestad no sea servido, ni a vuestras señorías y mercedes les pareciere de mandar que yo entre en los límites de ninguna de estas gobernaciones, para ver si hay puerto seguro a la mar del norte, pues como digo, ninguno de los otros gobernadores tiene ni manera para andar la costa y buscar puerto en ella; y pues en la costa de la mar del sur que participa esta gobernación se han descubiertos puertos y hay gran aparejo en ella, de hacer navios con que palaciendo a Dios se descubrirá por ellas muy gran cosa, para cuya conquista y población se a de llevar de aqui el socorro y es muy gran gasto y trabajo traer a esta gobernación lo necesaria desde el Puerto de San Juan de Ulúa, que hay trece leguas y el Pueblo de Guacagualco, donde hay puerto al Norte está cuarenta leguas de esta gobernación; suplico a vuestras señorías y mercedes, provean de que su Majestad me haga merced de aquel puerto y población para que esté debajo de esta gobernación, porque desde alli se puede proveer aquí de todo lo necesario para las armadas que de aquí saliesen para la mar del sur, pues de ello se espera tan gran provecho y para toda esta Gobernación muy gran bien y mercedes.

A Vuestra señorías y mercedes escribi, como de todos los agravios y fuerzas que se me hicieron en la tierra del Perú, por los que la gobernaban, no se me consintió que yo sacase testimonio ni hiciese ningún auto por donde yo 
pudiese quejarme a su Majestad y entre muchos que alli yo recibi, fue que yo jugué con el Mariscal Almagro y me gano trece mil y quinientos pesos en oro, en pago de los cuales le di ciertos negros y caballos y yeguas y vestidos y aderezos de caza que se tasaron y valían mucha más cantidad y lo recibió todo por pago de ello y después de entregado en ello de los pesos de oro que me quedó a dar por los navios que le vendí, se entregó otra ves de los dichos trece mil pesos y me los dio, menos de los que me habia de dar, por manera que él se pago dos veces, sin yo ser parte para cobrar lo mío y asimismo, el Adelantado Pizarro se me quedó con una ropa de mantas que valía dos mil ducados, sin me pagar cosa ninguna por ella. Y llegado a esta gobernación porque ni derecho no pereciese, yo hice provanza con caballeros y otras personas que vinieron del Perú y vieron esto que digo; lo cual envío a ese Real Consejo cerrada e sellada por donde constará ser así verdad. A vuestras señorías y mercedes suplico que de esto que el presente se averigua por vedad pues se pedirá en ese Real Consejo, por mi parte, mande se me haga brevemente justicia, porque yo no reciba tanta fuerza y agravios pues hasta lo que demás contra mi allí se hizo, de que espero ser también remediado por su Majestad y por ese Real Consejo, como yo les escribo. Nuestro señor, la muy ilustre y reverendísima persona y magnificas personas de vuestras señorías reverendísimas mercedes guarde y estado prospere y acreciente muy largo tiempos. De esta ciudad de Guatemala a veinte de noviembre de mil quinientos treinta y seis años. De vuestras sacras ilustrisimas mercedesmuy cierto servidor. El Adelantado Pedro de Alvarado."

De la acusación que saco gente de los vecinos y naturales de la gobernación, informó en su momento sobre su partida y pide que cuando se le acuse, ser él primero oído, antes que se provea contra él, ya que busca servir a su Majestad y la gobernación esta pacífica y prospera. En cuanto a la comisión que se le envía, de buscar puerto en el mar del norte, cerca de su gobernación, poblar en él una villa a donde pudiesen llegar los navíos de Castilla a dicha Provincia. La Reina gobernadora le envió una carta para que no se entrometiera en lo que toca a la Tierra de Naco o de Honduras, por cuanto había proveído por gobernador a Diego Albitel. Por otra parte, el adelantado Francisco de Montejo llegaba a poblar la tierra de Cozumel, Yucatán. Alvarado participa que en estas dos gobernaciones se encierra toda la costa de la mar del norte, que confina con su gobernación, de manera que él no puede entender en la Corona manda, sin entrar en los límites de estos gobernadores.

El viernes 4 de abril de 1539, viernes santo, arriba a Puerto de Caballos el Adelantado Pedro de Alvarado, juntamente con su nueva esposa, Beatriz de la Cueva, hermana de Francisca de la Cueva, primera esposa de Alvarado, fallecida, con tres naves, 250 hombres, caballeros, hijosdalgo, gente de guerra, armamento: 300 arcabuces, tiros de

${ }^{8}$ Fuente: AGI.AG.Leg.9. Carta relación escrita por Pedro de Alvarado dirigida a su Majestad sobre búsqueda de Puerto en la mar del Norte y San Miguel. 
artillería, 400 picas, 200 ballestas; más otras mercaderías valorables en especie que portaba su mujer: 20 doncellas españolas hijasdalgo, de oficio sus labores, bien educadas para casar:

\section{Metodología}

Enfoque metodológico.

En El Salvador no hay estudios monográficos sobre la historia moderna del pais, ni de las Instituciones del derecho y de las instituciones jurídicas que introdujeron los españoles en el país. Para comprender totalmente el proceso de introducción de los esclavos africanos debemos de ubicarnos en el contexto geográfico y conocer el país que ocupo la hueste indiana dirigida por el Capitán Mayor Pedro de Alvarado y el paso de la conquista a la pacificación para consolidar la policía castellana. La transición gradual suscita diferentes cuestiones de interés antropológico: ¿Quiénes son sus habitantes?, ¿Cómo se desarrolló la conquista militar del territorio? ¿Qué efectos tuvo la derrota militar entre los naturales?, ¿Qué ocurrió con las instituciones básicas de las culturas indígenas y española? : La familia, la pirámide de poder, el comercio del país, las prácticas religiosas, en el primer siglo de dominación española. El efecto de la cultura de conquista ¿Cómo afecto a las estructuras básicas del sistema económico? ¿Qué tipos de transformaciones económicas y sociales tuvieron lugar? Las respuestas a estas preguntas las encontramos en contextos semejantes y expresan generalmente un proceso de aculturación Pero, ¿se pueden hacer preguntas más precisas? En nuestro caso ¿Cómo se introduce, desarrolla y consolida la institución del Cabildo y Alcalde Mayor, con su status, normas y valores durante el siglo XVI? ¿Qué papel desempeñó la corona en esta etapa de transición? ¿Por qué se afianzan esta Institución mientras el Cabildo decae?

La realización de esta investigación y trabajo está promovido por varias razones. Entre ellas las anteriormente mencionadas, como buscar las respuestas de algunos interrogantes históricos que, aún hoy día, no han tenido respuestas con valor científico, ni metodológico, ya que al no existir informante vivo que nos aclare dichos hechos, solo podemos buscar la respuesta en el estudio de las sociedades del pasado y valerse de los únicos datos con que se cuenta, como son los testimonios escritos por los participantes en los hechos y que forman parte de los fondos documentales históricos que se custodian en los Archivos Generales de Centroamérica y Archivo General de Indias, (AGDCA y AGI).

Guatemala. C.A. y Sevilla, España, respectivamente, como de otras fuentes documentales en archivos, museos y bibliotecas de los grandes de España: Duques de Alba, Frías, etc. Todos los testimonios de la memoria histórica, se citan con la correspondiente asignatura, sección, número del legajo y número de expediente, Archivo General de Centroamérica, (AGDCA. ejemplo: A1. Legajo 42. Expediente 
453) Archivo General de Indias, (ejemplo: AGI. Audiencia de Guatemala. Leg. 110, N.18 y Ramo).

Aunque no pretendo caer en el trivialismo que los historiadores generalizamos a partir del estudio y análisis de las Instituciones, para explicar los hechos sociales, en nuestro caso, es justo y necesario continuar dicha línea, pero introduciendo las nuevas aportaciones en el estudio de las Ciencias Sociales, sin prescindir de la utilización de la metodología comparativa y cronológica, aplicada a una fuente documental que tenga diverso origen e interés, para reconstruir los valores característicos del pasado. Asimismo, he consultado otras secciones en dicho Archivo, como son: Justicia, que me ha facilitado el estudio de los pleitos habidos por concesión de encomiendas, abusos en cobro de tributos y enfrentamientos que ambas causas crearon entre los diferentes grupos y entre los encomenderos, donde podemos apreciar la conducta del grupo dominante; como el juicio de residencia a Pedro de Alvarado. Contaduría y Indiferente General, me ha conducido a diferente documentación que contiene datos misceláneos, en Contaduría, los documentos más importantes para nuestro estudio son las relaciones de vecinos y encomenderos de diferentes décadas; Indiferente General nos proporciona datos sobre disposiciones legislativas sobre el buen gobierno de las India; Patronato, sección muy especial para nosotros, ya que contiene los fondos documentales sobre probanzas públicas y secretas. De aquí he obtenido la información que me revela el comportamiento, las relaciones y concretamente, los caracteres civiles consecuentes del micro político que se desarrolla en la ciudad de Santiago, como en la villa y ciudad de San Salvador.

Cartas particulares dirigidas al Monarca en tono crítico-informativo en las que describen los momentos cambiantes o innovadores de una sociedad, como otros archivos particulares y del Estado. En los diferentes archivos que hemos mencionado anteriormente, larga y paciente tarea para dar cohesión y sentido a esta reunión de información, esquivando el peligro de hacer una sencilla comparación y ordenación cronológica de los mismos. De no hacerlo así, contribuiría a la parcialidad histórica de unos informantes que en su día fueron los que escribieron y protagonizaron los hechos plasmados en los documentos. Cabe hacer mención que la información que encontramos en la documentación, evidentemente, nos condiciona, ya que fue hecha con un fin específico: nombramientos, de cargos, entrega de repartimientos, solicitud de mercedes, quejas sobre el reparto de repartimientos, de encomiendas, compra de oficios, concesión y explotación de esclavos y de recursos, ya que los protagonistas, conociendo la generosidad de la Corona por los servicios prestados en Indias, no dudan en exigir. La confrontación de la información obtenida de varios informantes que provienen de los distintos niveles y diferentes intereses, como la aportación de nuestro análisis, nos llevan a conocer los barremos real e ideal, en el estudio de la incipiente sociedad de la provincia de San Salvador. 
Los nuevos estudios de las Ciencias Sociales han contribuido al análisis semántico para profundizar en el conocimiento de culturas actuales, existe estrecha colaboración entre historiador y especialistas en otras especialidades para obtener mejor comprensión de las sociedades estudiadas, por lo qué, mayor relevancia será buscar en las expresiones verbales al analizar comunidades para cuyo estudio sólo tenemos el lenguaje empleado en la escritura de su memoria histórica. En los testimonios documentales que he paleografiado, transcribo fielmente la provisión o real cédula, la carta-relación o solicitud de merced, probanzas de méritos y servicios, registro de pasajeros a indias, para aclarar y llenar los vacíos documentales que los estudiosos de la "historia de controversia" no han encontrado, inventado, supuesto, probable o posibles sin apoyo documental, aquí encontramos los datos, fechas aproximadas, ya que los blancos castellanos no eran dados a aportar fechas exactas, las palabras, giros empleados, repetición insistente, continua de conceptos y al analizarlos dentro del contexto histórico del siglo XVI, nos permiten conocer profundamente a una sociedad; sus acciones individuales, sus creencias, nivel que se puede definir como real, como así mismo, el de la interpretación, en otras palabras, las valoraciones que hacen ellos mismos de su entorno cultural, de sus hechos cotidianos. Se nos hará la observación del porqué no lo interpretamos, pero insistimos, nuestra aportación a la historia de El Salvador, son los testimonios documentales, pues dan contestación y respuesta a los vicios de los cronistas y sus escuelas. Esto no quiere decir, que no se haga un análisis e interpretación, pues no todos los documentos se han trascrito, como se puede comprobar a través del estudio se va realizando el mismo y al final se presentan las conclusiones que dan respuestas a cualquier duda. En nuestra aportación documental, conocemos así lo que los conquistadores, vecinos y solicitantes de la villa de San Salvador, realizan, es más, lo que según ellos, deberían hacer, esta dualidad es de mayor relevancia en nuestro trabajo, por la insistente repetitiva a través del siglo XVI.

Esta última fase oral o ética es la que cuantitativamente y cualitativamente he tomamos para nuestro estudio, pues insisto, que esta investigación o estudio está enfocado principalmente en el análisis de la introducción, desarrollo y consolidación de dos Instituciones como es el cabildo, sus vecinos y al Alcalde Mayor, pero que no es ajena al sistema de valores de los hombres que integraron las diferentes huestes indianas que se asentaron en la provincia de San Salvador, sus vecinos pobladoresencomenderos, funcionarios reales. Aunque provenían de diferentes lugares, tenían los mismos intereses y objetivos: recibir la gracia de la corona por los servicios prestados, sedentarizarse en una tierra que consideraban suya, la patria chica, para los primeros, para los funcionarios y alcaldes mayores, buscar los medios para enriquecerse rápidamente.

En esta documentación todo un cúmulo de emociones aparece sin trabas y es precisamente el lenguaje que he calificado de emocional, el que encuentro en los documentos que transcribo tras el habitual encabezamiento estereotipado. Presentación del interesado, queja, situaciones de disgusto, enfado, aprobación, dolor, lamento, discriminatorios, prepotencia, situaciones extremas: pobreza, hambre, 
muerte, etc., plasmadas literalmente con ese lenguaje liberado aparecen claramente en la documentación utilizada; y aún mejor, en los pleitos podemos ver de forma más directa el citado uso personal de la terminología cotidiana; insultos, exabruptos y escenas de enfrentamiento y disputas son descritas con tal detallismo que nos permiten estar presentes, de alguna manera, en las villas y después ciudad de San Salvador, San Miguel de la Frontera y Jerez de la Frontera de la Choluteca y Villa de la Trinidad a lo largo del siglo XVI.

1531 "Cedula a Fernando de Montemayor, dándole licencia para pasar a Indias dos esclavos negros, para servicio personal". 9

1532. Esclavos indígenas pipiles en minas de vecinos de San Salvador

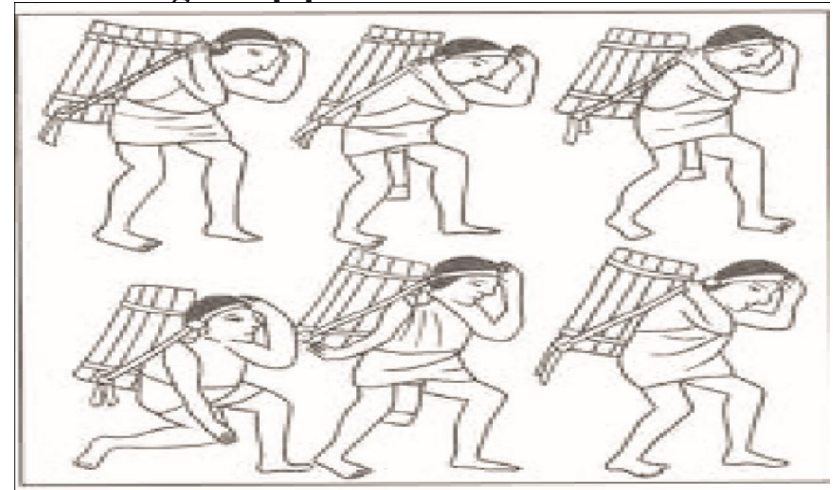

\footnotetext{
${ }^{9}$ Fuente: Archivo General de Indias. INDIFERENTE,422,L.15,F.76V(8)1531-9-9 este documento disponible de imágenes digitalizadas
} 

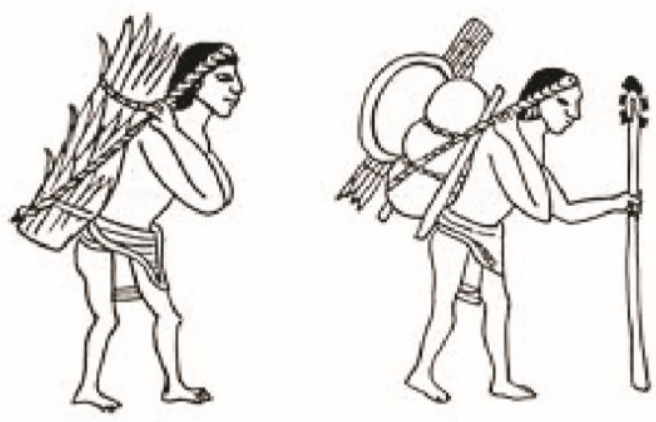

Fuente: Tamemes: Códice Florentino y Mendoza.

El presidente de la Audiencia de los Confines, Alonso Maldonado, al nombrar a sus parientes en los cargos, no era ajeno a las riquezas de algunos pueblos del Reino de Guatemala. Su experiencia como Juez de Residencia contra Pedro de Alvarado, le hicieron conocer las regiones y comunidades más productivas, ya que el mismo Adelantado se valió de ellas presionando a los encomenderos, especialmente a los de la Provincia de San Salvador. Dentro de este territorio, fronteras occidentales de Guatemala, está la región de los pueblos de Izalcos, pueblos productores de cacao, que en 1532, estaban encomendados a Diego López de Toledo, Caluco, y Antonio Diosdado, Tecpán Izalco, desde 1535, los españoles encomenderos, habían incorporado a su ecosistema, como productores de exportación, pero no por cultivarlo, sino como medio de pago de tributos impuestos a las comunidades productoras.

\begin{tabular}{|l|l|}
\hline Nombre Encomendero. 1532. & Pueblo en encomienda. \\
\hline Diego López de Toledo. & Caluco. \\
\hline Antonio Diosdado. & Tecpán Izalco. \\
\hline
\end{tabular}

Cuadro $\mathrm{N}^{\circ}$ 1. Pueblos encomienda Caluco Izalco.

El nombramiento de sus parientes en puestos claves, Chancillería, visitador de minas de Guatemala, visitador de minas de San Miguel y el más importante en la estrategia económica de Guatemala y San Salvador, visitador de Guatemala, con repartimiento de indígenas, cuya renta es de 3000 pesos. Aquí da inicio a lo que nosotros hemos denominado el "grupo de Salamanca"; Juan de Guzmán, astuto y codicioso, sin ser 
conquistador, será el que más beneficios obtiene, controla el comercio del cacao y tiene su red con: Francisco Xirón, Juan Vázquez de Coronado, Juan Maldonado que a través del siglo XVI, el primero dominará controlará y ejercerá el poder económico, político y social en Santiago de Guatemala, al convertirse en encomendero de Tecpan Izalco. Introduce los esclavos negros en los Izalcos.

“...se tiene entendido que tuvo origen lo que se dira. Pues como començo a subir el cacao y a tener precio, comenzaron estos encomenderos y principalmente, Juan de Guzmán que fue un hombre de extraña codicia y así saco de su repartimiento en dos veces que fue a España, setenta mil pesos, de que hizo dos mayorazgos que ahora está en uno, y casó dos hijas en Salamanca, que los demas dos cavalleros eran perdidos..." "I0

Le sucederá su hijo Diego de Guzmán, que heredará las mañas y superar al padre en el arte de explotación del indígena, provocará estafa y fraude al tasar su encomienda, muchos años más adelante, arropado por funcionarios y estómagos agradecidos.

\section{Origen "Grupo de Salamanca"}

\begin{tabular}{|l|l|}
\hline Nombre encomenderos 1532. & Pueblo encomendado. \\
\hline Diego López de Toledo. & Caluco \\
\hline Antonio Diosdado. & Tecpan Izalco. \\
\hline Encomenderos 1540. & \\
\hline Juan de Guzmán, pariente del Presidente.1540. & Tecpan Izalco. \\
\hline Francisco Xiron. & Caluco. \\
\hline Juan Vázquez de Coronado. & Cuzcatlan. \\
\hline Juan Maldonado. Pariente del Presidente. & Izalco. \\
\hline Diego de Guzmán (hijo de Juan de Guzmán). & Tecpan Izalco. \\
\hline
\end{tabular}

Cuadro $\mathrm{N}^{\circ}$ 2. Nombre encomenderos 1532.

"Pero Núñez de Guzman, vecino de la dicha villa, habiendo jurado según forma de derecho, dijo: que él tiene por repartimiento la mitad del pueblo de Cuscatlán y que tendrá cuatrocientas casas, pocas más o menos y doscientas en los chontales en un

${ }^{10}$ Fuente: AGI.AG.Leg.9. 
pueblo que se dice Colquin, que unas veces sirven y otras no por ser chontales y que ha estado en él y por eso no sabe los términos que tiene ni pastos ni si en él se darán frutas, ni pan y vino de España, y que aquellas veces que le han venido a servir le han dado y traído algún ocote y algunas gallinas y miel, y que la dicha mitad de Cuzcatlán es tierra donde se da bien el maíz y le dan de tributo ropa y gallinas y miel y cera y otros bastimentos de casa, y le hacen sus sementeras de maíz y frisoles y axi y algodón y que en el se sustentan puercos y que el dicho maíz y piñas y otras frutas de la tierra se sustentan los dichos naturales y tratan, y que los términos del son hacia la una parte dos leguas y hacia otra una y media y una poco más o menos y que piensan que se criaran en el vacas y ovejas y es tierra que cree a su parecer que se darán pan y vino, frutas y otras plantas de Castilla, por ser esta su parte de pueblo templada y algo fría, la cual dicha su mitad no tiene sujeto ni otro repartimiento de lo que dicho tiene, ni en el dicho pueblos hay minas aunque las han buscado y que los dichos indios no le dan oro, y que en compañía de otros dos vecinos de la dicha villa, cogió una demora o dos con sus esclavos y los abastecían de todo tres y que esta es la verdad para el juramento que hizo y fírmalo de su nombre. Pero Núñez de Guzmán. Rubricado.

Gaspar de Cepeda, vecino de la dicha villa, habiendo jurado según forma de derecho, dijo: que él tiene por repartimiento, el pueblo de Naozalco y que tiene, cree y piensa, cuatrocientas casas, pocas más o menos, porque nunca lo ha podido contar porque está muy derramado/fol. $13 \mathrm{v}^{\mathrm{o}}$./ y que tiene de términos a cada parte media legua y a partes no porque tiene a la redonda de si muchos pueblos y que es tierra áspera y montuosa de montes y barrancas y que es tierra templada y que es tierra queda bien maíz y algodón y que no sabe si se darán pan y vino de Castilla y buenas plantas de Castilla, que cree que se darán así naranjos y limones, sidros y otras plantas de esta calidad y no es tierra para ganados por la mucha aspereza y pocos términos, y el daño que los naturales recibirían, y que el tributo que le dan es ropa, maíz, frisoles, axi, gallinas, cera, miel y que los naturales de este dicho su pueblo se sustentan y mantienen de algodón y de otras granjerías, que él no sabe ni lo alcanza y que no le dan oro ni se lo pide, y que también le sirven los dichos indios de le sustentar sesenta o setenta esclavos en las minas a veinticinco leguas, poco más o menos y que a si mismo tiene otro pueblo que se dice Guazapa el cual tiene treinta y cinco casas, pocas más o menos y que no le dan tributo ninguno más de servirle en casa de traerle agua y leña y otras cosas necesarias y que tiene muchos términos y manera para que se críen ovejas y vacas en ella porque es tierra llana y llena de piedras, y asimismo tiene otro pueblo Chontal que se dice Zitala, que tendrá cien casas, pocas más o menos a los que sus naborías le han dicho y otros indios, los cuales no le sirven ni saber los términos que tiene, pero que sabe que en estos dichos sus pueblos no hay minas ningunas ni se piensa que las habrá ni si en estos otros dos pueblos se dará las dichas plantas ni frutas de Castilla y que estas es la verdad para el juramento que tiene fecho. Fírmelo de su nombre. 
Juan de Arévalo, vecino de la dicha villa, habiendo jurado según forma de derecho, dijo: que él tiene por su repartimiento, el pueblo de Chalchuapa el cual tiene trescientas casas, pocas más o menos y que no tiene sujeto ninguno y que tiene de términos a todas partes una legua, poco más o menos, y que es tierra caliente y que parte de ella es áspera y parte llana y que es tierra de los frutos de Castilla y de maíz y algodón, abundosa y que no es tierra para pan ni vino, porque él lo ha sembrado y no se dan, más que las plantas de Castilla cree que se darán y cierto cañafistolos que los ha sembrado y no han nacido y que la tierra es buena para ganados, salvo que tiene mucha falta de agua y que o le dan otro tributo ninguno salvo sustentarles cien esclavos en las minas y darle ropa para ello y no otra cosa y algunas gallinas y de lo que viven y tratan los naturales es de maíz y de algún cacao y que o le dan oro y que no tiene minas en el dicho pueblo ni espera que las habrán y que esta es la verdad y firmolo de su nombre. Juan de Arévalo. Rubricado."11

\section{El oro y plata de la provincia de Guatemala y San Salvador. 1532}

El adelantado Pedro de Alvarado, la ciudad de Santiago, los vecinos de Guatemala y San Salvador, envían el oro y plata que se había obtenido en la provincia, para congraciarse con la corona y obtener las mercedes que Gabriel de Cabrera, natural de natural de Zafra, procurador en la corte, solicitará. El viaje de Cabrera hasta llegar a Sevilla, presenta las dificultades de transporte, registro del oro y plata, agregado el robo que hicieron el Maestre y contramaestre al llegar a Sevilla.

Proceso: "Sevilla año de 1532. Gabriel de Cabrera vecino de la ciudad de Santiago de Guathemala. Con Blas Gallego y Pedro de Ochoa, que son de la ciudad de Sevilla, Maestre y contramaestre de una nao San Juan, por ciertos pesos de oro. Que se embargase el oro y plata que en ella suyo y de particular, hasta que pareciese cierta cantidad que habían hurtado del que venía para su majestad." "Mil e trecientos pesos"13

El proceso finalizo con la devolución del oro y plata a Gabriel de Cabrera, que hacían un valor de "cinco mil castellanos de oro de minas"'l4 que entrego a su Majestad.

${ }^{11}$ Fuente: AGI.AG.Leg.965. Fol.1-18.

12 Fuente: AGI. Justicia 706 No 4, pieza 1. Gabriel de Cabrera vecino de la ciudad de Santiago de Guathemala. Con Blas Gallego y Pedro de Ochoa que son de la ciudad de Sevilla, Maestre y contramaesre de una nao San Juan. ciertos pesos de oro. Que se embargase el oro y plata que en ella suyo y de particular hasta que pareciese cierta cantidad que habían hurtado del que venía para su majestad.

${ }^{13}$ Fuente: AGI. Pleito Fiscal: Gabriel de Cabrera Archivo General de Indias,JUSTICIA, 822,N.3,R.1.

${ }^{14}$ Fuente: AGI. Pleito Fiscal: Gabriel de Cabrera Archivo General de Indias,JUSTICIA,822,N.3,R.1. 
En la corte, Gabriel de Cabrera, procurador en nombre de los cabildos de GuatemalaSan Salvador, había solicitados las mercedes y propios para los gastos de las ciudades y villas.

El 24 de Mayo de 1532, se daba una real cédula en Medina del Campo, concediendo dichos fondos:

"para que se gasten e distribuyan en cada pueblo en caminos y puentes e casas de Cabildo e cárceles e no en otra cosa alguna." 15

El 15 de Julio de 1532, se da otra cédula real a favor de Gabriel de Cabrera, procurador nombrado por las ciudades, villas y lugares de la provincia de Guatemala-San Salvador... "me han suplicado y pedido por merced que en remuneración de los diezmos de la dicha villa de San Miguel que así fuimos mandado adjudicar al obispado de Honduras, le hiciésemos merced de mandar adjudicar al dicho obispado de Guatemala la dicha villa de San Cristóbal de Chiapa"'16

En mi investigación sobre la introducción de los los esclavos negros en Guatemala, El Salvador y Honduras, aprovecho ocasión para poner el hecho real, he paleografiado los folios 309-313, del largo proceso de memoria histórica (913 folios), del primer envío del oro de Guatemala y la provincia de San Salvador en 1532.

..."Y luego el dicho Gabriel de Cabrera dijo que demás del dicho oro que tiene declarado lleva de personas particulares que le encomendaron en Guatemala, las partidas de oro siguientes:

Primeramente declaro que lleva de Martin de Martin de Martiarte, ciento y cuatro pesos e medio de oro de ley de diez y nueve quilates, para dar a su majestad, van a su riesgo. CIV pesos y medio.

Declaro más que lleva de Antonio de Campo, vecino de la villa de San Salvador, de Guatemala, cincuenta pesos de oro marcado de ley perfecta, van a su riesgo .L pesos.

Item declaro que lleva de Sancho de Barahona, vecino de la ciudad de Santiago de Guatemala, cuarenta pesos de oro marcado de ley perfecta. Van a su riesgo XXXIL pesos.

Declaro más que lleva de don Pedro Portacarrero, vecino de la dicha ciudad, cuatrocientos pesos de oro, reducidos en ley perfecta. XXXX pesos.

\footnotetext{
${ }^{15}$ Fuente: AGI.AG.Leg.393.Fol 26.

${ }^{16}$ Idem.
} 
Declaro que más que lleva de Alonso Pérez, vecino de la dicha ciudad, veinte pesos de oro de veinte y unos quilates, van a su riesgo. XX pesos.

Declaro más que lleva de Alonso Sánchez de Liébana, vecino de la dicha ciudad, para dar a su mujer en Sevilla, pedazo de oro de veinte y un quilates, cosido en lienzo, no sabe lo que pesa, va su nombre en cima, va a su riesgo.

Declaro más que lleva del tesorero Francisco Cobos de Castellanos, ciento e ochenta pesos de oro de ley, de diez y nueve quilates, para dar en Sevilla, van a su riesgo CLXXX pesos.

Declaro más que lleva de Carlodano, fundidor, veintidós pesos de oro de ley perfecta, van a su riesgo. .XXII pesos.

Declaro que lleva de la cofradía e de la iglesia de la dicha ciudad, cuatrocientos e sesenta y cinco pesos de oro de ley de veinte y un quilates, van a su riesgo CXXXV pesos.

Declaro más que lleva de la dicha cofradía e iglesia, ciento e veinte pesos e cuatro tomines de oro de veinte quilates, van a su riesgo. XX pesos. IV tomines, Declaro más que lleva de Pedro de Nalto, vecino de la dicha ciudad, veinte pesos de oro de veinte quilates, van a su riesgo. XX pesos.

Declaro más que lleva del señor comendador Francisco de los Cobos, trescientos noventa y tres pesos e seis tomines de oro de ley perfecta, van a su riesgo. XXXCIX. Pesos, VI tomines.

Declaro más que lleva de don Pedro de Alvarado, gobernador der la provincia de Cuatemala, tres piezas de oro labrado, que son un bernegal, que pesa trescientos y tantos pesos, e un salero que pesa doscientos e tantos, e una caja que pesa ciento e ochenta e tantos pesos de oro, van a su riesgo.

Declaro más que lleva del dicho gobernador cuatro calatos e trece pesos de oro de ley perfecta, van a su riesgo. IV.XIII pesos.

Declaro más que lleva del contador Francisco de Zorrilla, ciento e cuarenta e un pesos de oro de oro de ley de veinte e un quilates, van a su riesgo. CXL.I pesos. Declaro más que lleva del licenciado Francisco Marroquín, una bolsa de cuero, cierta cantidad de oro, que no sabe cuánto pesa, que va encima su nombre, va a su riesgo. Gabriel de Cabrera." ${ }^{17}$ El proceso finalizo con la devolución del oro y plata a Gabriel de Cabrera,

${ }^{17}$ Fuente: Blas Gallego contra Gabriel de Cabrera. Archivo General de Indias,JUSTICIA,706,N.4 - 75 Imagen Núm: 309-313 / 913 
Cabrera Rajo. Sigfredo. Introducción de los Esclavos negros africanos en el reino de Guatemala y provincias de San Salvador y Honduras. Págs. 82-172.

DOI: http://dx.doi.org/10.5377/koot.v0i8.5872

URI: http://hdl.handle.net/11298/386

que hacían un valor de "cinco mil castellanos de oro de minas" 18 que entrego a su Majestad.

Gabriel de Cabrera, como procurador, obtuvo varias mercedes de la Corona.

\section{2, Introducción de los los primeros esclavos africanos por vecinos de Guatemala}

En Segovia el once de octubre de 1532, se da una real provisión a Gabriel de Cabrera.

"Gabriel de Cabrera.(al margen) Por la presente doy licencia y facultad a voz Gabriel de Cabrera, para que de estos nuestros reinos e señorios podáis pasar e paséis a las nuestras indias, islas e tierra firme del mar océano, dos esclavos negros para servicio de vuestra persona y aya llendo voz a poblar e conquistar las dichas indias y no de otras manera habiendo pagado a Diego de Lasaya cambio de nuestra corte los doce ducados de la licencia de cada uno de ellos por cuanto el por nuestro mandado tiene cargo de los cobrar fecha en Segovia a once días del mes de octubre de mil quinientos treinta y dos años, yo la reina, refrendada de Samano,señalada del conde Núñez Bernal Izquierdo." ${ }^{19}$

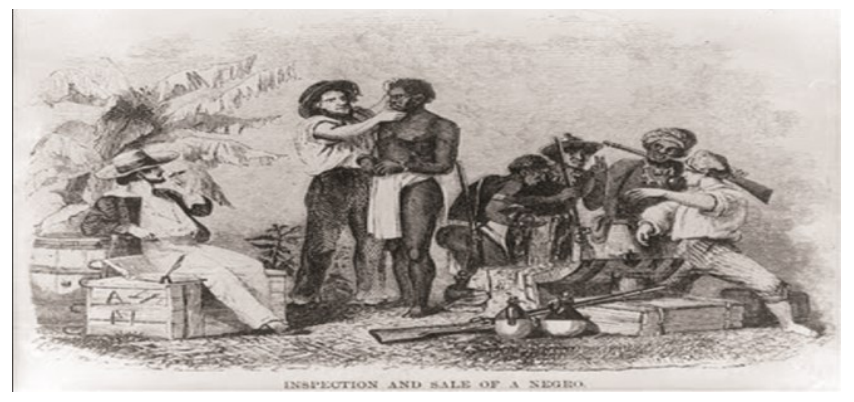

Fuente: Imágenes.cienciassocialesacs.blogspot.com.

E1 24 de Mayo de 1532, se daba una real cédula en Medina del Campo, concediendo dichos fondos:

"para que se gasten e distribuyan en cada pueblo en caminos y puentes e casas de Cabildo e cárceles e no en otra cosa alguna." 20

\footnotetext{
${ }^{18}$ Fuente: AGI. Pleito Fiscal: Gabriel de Cabrera Archivo General de Indias, JUSTICIA,822,N.3,R.1.

${ }^{19}$ Fuente: Real cédula a Gabriel de Cabrera, dandole licencia para pasar a Indias dos esclavos negros, para servicio personal. Archivo General de Indias,INDIFERENTE,422,L.15,F.189R189V.

${ }^{20}$ Fuente: AGI.AG.Leg.393.Fol 26.
} 
La seguridad que presentaba la villa, hará que algunos vecinos de la misma, una vez consolidados en sus encomiendas, solicitan licencia para venir a la Corte de Castilla y poder casarse y llevar a su mujer o parientes a las tierras de Cuscatlán. La necesidad de organizar la familia nuclear castellana empiezan a preocupar a los habitantes y es así como se darán las primeras licencias, aunque no todos podían hacerlo, por falta de medios, conformándose hacer hogar con las mujeres indígenas que dará origen al mestizaje.

El 15 de octubre de 1532 por capitulación de la Corona con Pedro de Alvarado, gobernador de Guatemala, para que descubra, conquiste y pueble cualquier isla que hay en la mar del sur de la Nueva España, se expide una real cédula a favor de Pedro Portocarrero nombrándole tesorero de las tierras y provincias que se descubrieran y conquistaran. A Gabriel de Cabrera como contador de las mismas.

El 15 de octubre de 1532, se expide una real cédula a favor de Pedro Puertocarrero Tesorero nuevos descubrimientos:

16. El 15 de octubre de 1532, expide una real cédula a favor de Gabriel de Cabrera como contador de nuevos descubrimientos:

17. 1533. 19 de marzo de 1533, sobre la esclavitud de los caciques en guerra. Para los conquistadores, según su idea:

“...al tiempo que se repartió esta tierra después de conquistada, los pueblos de indios que estaban en la serranía se tenían por mejores repartimientos que no los de la costa y tierra llana porque participaban de las minas de oro y así, a los principales hombres se les dio en la serranía repartimientos, porque como tenían esclavos indios en aquella sazón sacaban mucho oro y eran los más ricos y después como se quitaron los esclavos, los que tenían tales repartimientos muchos de ellos quedaron con muy poca renta...y a los que acertaron a dar repartimientos en la costa que dan cacao son los ricos..." 21

El 19 de marzo de 1533 para hacer esclavos Indígenas, Se expedía una real cédula en Belpuche que condenaría a los caciques que estaban en guerra defendiendo su libertad, tierra y gente a que fueran tomados como esclavos y como tales repartirlos entre los castellanos que les vencieran. Obligando al licenciado Francisco Marroquín y al gobernador Pedro de Alvarado:

"...vos mandamos que vosotros en persona, juntos o el uno de vosotros, estando el otro ausente o impedido, vais a donde estuvieren los dichos indios alzados e les hagáis el requerimiento que está acordado que con ésta vos enviamos... "22 De no haber respuesta se les haga la guerra, capturarlos y venderlos como esclavos, pero que no se saquen de

${ }^{21}$ Fuente: Pilar Sanchiz Ochoa "Los Hidalgos de Guatemala". Publicaciones del Seminario de Antropología Americana. Vol. 13-1976. págs.46-47.

${ }^{22}$ Fuente: AGI.AG.Leg. 93. Fol.136v'. 
la Provincia de Guatemala. Se derogan y anulan las cédulas que se han publicado con anterioridad, dejándolas sin efecto. " 23

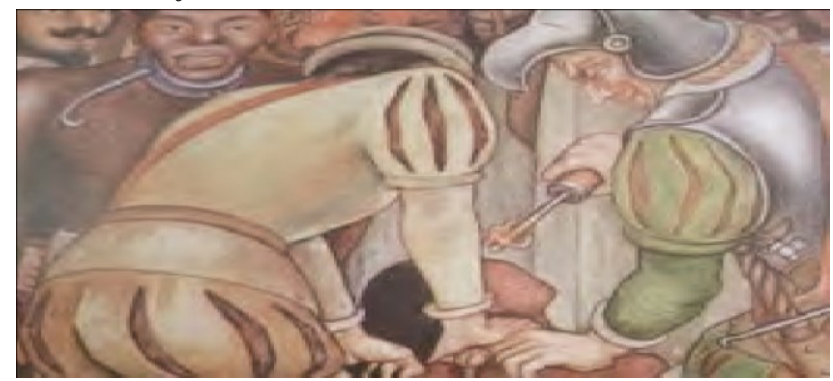

\section{8. "Al licenciado Marroquín, al Gobernador don Pedro de Alvarado o su Alcalde Mayor}

"Gabriel de Cabrera en nombre de los vecinos, Concejo, Justicias e Regidores, caballeros, escuderos, oficiales e hombres buenos de las ciudades e villas e lugares de dicha provincia, nos ha hecho relación que en esa tierra diz que hay algunos caciques de guerra, que aunque han sido requeridos no quieren estar debaxo de nuestra obediencia a señorío e admitir la predicación xpiana, antes han fecho o hacen daños a los xpianos. E nos suplica e pidió por merced, les diesemos licencia para que no queriendo estar en nuestro servicio a admitir la predicación xprina, los pudiesen hacer guerra y tomarlos por esclavos y como a tales repartirlos entre las personas que los ganasen e prendisen. Vos mandamos que vosotros en persona juntos o el uno de vos otros estando el otro ausente o impedido váis a donde estuvieren los dichos indios alzados e les hagáis el requerimiento que está acordado que con esta vos enviamos, señalado de los del nuestro Concejo de Indias. Así por caso todos estuviéredes ocupados empedidos, que no podáis cómodamente ír, nombréis en vuestro lugar dos personas religiosas o clerigos sacerdotes de buena conciencia e confianza en cuya presencia el Capitán que fuere, haga los dichos requerimientos en la forma suso dicha se ayan de tomar y examinar por vosotros e ansy vistos si os pareciere que con justicia se les pueden hacer guerra lo declaréis ansy e ansy declarado por vosotros, por la presente damos licencia a cualesquier personas de esa dicha tierra que puedan hacer la dicha guerra e a los que en ella prendieren tomarlos por sus esclavos y como a tales venderlos, sin embargo de cualesquier nuestras cartas e provisiones en que por ellas ayamos prohibido la dicha guerra e cautiverio, con tanto que no se puedan sacar, ni saquen desa dicha provincia de Guatemala. Dada en Belpuche a diez y nueve días del mes de marzo de mil e quinientos e treinta y tres años. Yo la Reyna Refrendada de Samano y firmada del Conde y Beltrán y Suarez y Mercado"24

Los pueblos pipiles, pokomanes, lencas y chorties de la futura provincia de San Salvador, por su rebeldía, resistencia y libertad, padecerán en adelante, el sistema de la esclavitud, que la corona suprimira, pero la realidad es otra, ya sea real o camuflada en encomienda,

${ }^{23}$ Fuente: Idem.
${ }^{24}$ Fuente: AGI.AG.Leg.393. Libro.2. R.C.3. 
repartimiento y las diversas formas de explotación que se inventaron los españoles durante la colonia, continuada luego por las diferentes generaciones contemporáneas que dirigen el país.

\section{1533}

"Real cédula a los oficiales de la Casa de la Contratación para que entiendan traspasada a Manuel de Maya la licencia concedida a Hernando de Montemayor y Pedro de Alvarado para pasar esclavos negros a Indias." 25

20. 1534. Por capitulación de la Corona, Pedro de Alvarado prepara su armada para su próxima aventura en 1534 en el puerto de Iztapa, donde entraban fragatas y pequeños navíos, catorce leguas de Guatemala en busca de las islas de la especiería. En las obras emplea la mano de obra indígena para cortar madera, acarrear tablas, hacer pez y traer municiones desde el desembarcadero de Guazacalco en el mar del norte al sur, el terreno no permite el empleo de recuas por la aspereza de la tierra y le obliga a ocupar tamemes (indios para cargar), pues era corriente que mercaderes de Veracruz a la ciudad de Guatemala, dierán este trabajo a los indígenas para transportar sus mercaderías, los gastos son excesivos, ya que tiene que pagar a maestros carpinteros castellanos y el empleo de esclavos negros que compró para las tareas más pesadas.

Melchor Hernández que llegó a Santiago, no pudo embarcarse y lleva tres caballos, dos esclavos negros y cuatro esclavos oficiales y armas para la guerra.

\section{AÑO DE 1535, NOVIEMBRE 20}

Carta dirigida a su majestad por el Adelantado PEDRO DE ALVARADO, haciendo relación a su carta de fecha 12 de mayo sobre la comisión para que buscase puerto en la mar del norte y información sobre descubrimiento de un puerto en la boca del río Lempa, donde se ha poblado una villa que llaman de San Miguel.

\section{“MUY ILUSTRE Y REVENDERISOMO SEÑOR Y MAGNIFICOS SEÑORES}

A doce de mayo de este año escribí a vuestras señorías y mercedes, dándoles cuenta de lo que me sucedió en la tierra del Perú a donde aporte con mi armada y de venida a esta gobernación y ciudad de Guatemala, y el estado en que hallé las cosas de esta provincia, y como por cosas que cumplan al bien de ella y al servicio de su Majestad, no podía ir luego a besar sus reales manos como lo traía pensado hacer...A Vuestra señorías y mercedes escribí, como de todos los agravios y fuerzas que se me hicieron en la tierra del Perú, por los que la gobernaban, no se me consintió que yo sacase testimonio ni hiciese ningún auto por donde yo pudiese quejarme a su Majestad y entre muchos que alli yo recibí, fue que yo jugué con el Mariscal Almagro y me gano trece mil y quinientos pesos en oro, en pago de los cuales le di ciertos negros y caballos y yeguas y vestidos y aderezos de caza que se tasaron y valían mucha más cantidad y lo recibió todo por pago de ello y después de entregado en ello de los pesos de oro que me quedó a dar por los navios que le vendí, se entregó otra ves de los dichos trece mil pesos y me los dio, menos

${ }^{25}$ I Fuente: Archivo General de Indias NDIFERENTE,422,L.15,F.233R(2) 1533-3-8 
de los que me habia de dar, por manera que él se pago dos veces, sin yo ser parte para cobrar lo mío y asimismo, el Adelantado Pizarro se me quedó con una ropa de mantas que valía dos mil ducados, sin me pagar cosa ninguna por ella. Y llegado a esta gobernación porque ni derecho no pereciese, yo hice provanza con caballeros y otras personas que vinieron del Perú y vieron esto que digo; lo cual envío a ese Real Consejo cerrada e sellada por donde constará ser así verdad... A vuestras señorías y mercedes suplico que de esto que el presente se averigua por verdad pues se pedirá en ese Real Consejo, por mi parte, mande se me haga brevemente justicia, porque yo no reciba tanta fuerza y agravios pues hasta lo que demás contra mi alli se hizo, de que espero ser también remediado por su Majestad y por ese Real Consejo, como yo les escribo. Nuestro señor, la muy ilustre y reverendísima persona y magnificas personas de vuestras señorías reverendísimas mercedes guarde y estado prospere y acreciente muy largo tiempos. De esta ciudad de Guatemala a veinte de noviembre de mil quinientos treinta y seis años. De vuestras ilustrisimas mercedes. Muy cierto servidor el Adelantado Pedro de Alvarado"26

22. 1537. CONQUISTA Honduras. /Fol.1/ Carta dirigida a su Majestad por el Adelantado Don Francisco de Montejo, Adelantado de Higueras y Honduras,

\section{"Fol.1.1537. Honduras. SACRA CESARIA CATOLICA MAGESTAD.}

Higueras- Desde la villa de San Pedro del Puerto de Caballos hice relación a vuestra magestad, como ya habrá mandado ver, y después por otras postreras y breve carta que escribi a vuestra Majestad, por fin de mayo de este año, de lo que hubo que hacer saber a vuestra Majestad además de la relación que digo. Lo que ahora hay que hacer saber a vuestra Majestad es, que el Licenciado Maldonado, Gobernador de Guatemala, ha venido a meterse en los términos de esta gobernación, junto a la ciduad de Gracias a Dios, a catorce leguas de ella, que es en lo mejor que ella tiene, así para poderse sustentar, como para la pacificación de toda la tierra que ella tiene, y a cuarenta y tres leguas de la ciudad de Guatemala, y que ningún srvicio le puede allá hacer. Escribiome el licenciado que él venía a importunación de los vecinos de Guatemala y después de llegado a aquellos pueblos que él había visto que bien conocía, cuanta razón habia que sirviesen aquellos pueblos a esta Gobernación de Higueras, y que él haría de ello relación avuestra Majestad y al Visorrey de la Nueva España, no se si lo ha hecho así, y que en tanto que me rogaba que dejase aquellos pueblos a Guatemala, yo le respondí lo que s sufría que era que aquellos pueblos que estaban acá repartidos y que Don Pedro de Alvarado los repartió cuando vino al socorro de esta gobernación, en ella, como hombre que sbia bien la verdad, que sirvisen a esta gobernción, que sirven en la Gobernación de Guatemala, porque el adelantado Don Pedro de Alvrado, a causa de tenerlo sus deudos y amigos, no se los quiso quitar, que los tenga hasta que vuestra majestad mandáse pro/Fol.1.v\% veer en ello lo que se más servido, (Al margen: Que se traiga Esta provisión al Consejo,) y consta fue Juan de Montejo mi hermano, a verse con el Licenciado a la Villa de San Salvador, no se lo que se concertaron, despues que venga lo haré saber a vuestra Majestad, pero todabía quiero treaer a la memoria de Vuestra Majestad, como ya habrá mandado ver por mis relaciones que todo lo del río de Lempa

26 .- fuente: Archivo General de Indias. Audiencia de Guatemala.Legajo. 9.

CUniversidad Tecnológica de El Salvador 
al Levante, con la Villa de San Miguel, es de esta Gobernación, cmo parecerá por la Provisión que Vuestra Majestad les mandó dar a pedimento dela dicha gobernación de Guatemala. Suplico a vuestra Majestad sea servido de mandar hacer merced a esta Gobernación, que no se le quite lo que es suyo y lo tiene dado, y le pertenece, pues que la Gobernación de Guatemala tiene señalados términos y a su pedimento, y esto sea con mucha brevedad, por evitar escándalos que yo no tengo de consentir que se meta en más de que he dicho, hasta que Vuestra Majestad lo mande proveer y remediar como sea más servido... Loado Nuestro señor esta todol o más de esta Gobernación pacífico y sosegado, y se ve porque desde que llegue a la tierra, he traido mucha gente por todas partes a pacifidarla y ha servido que se haya hecho sin haber muerto en la guerra cincuenta indios, ni haberse prendido cien esclavos en toda ella. Espero en Dios Nuestro Señor que pasado este invierno y venida la seca, de ír a poblar la villa que a vuestra majestad he hecho relación, en la mejor de la tierra, porque toda lo más de ella, esta de paz y tengo alli un Capitan con gente, que estoy haciendo sembrar los naturales de la tierra, poque no nos falte el tiempo de la población, porque no nos acaezca lo que hasta ahora, que de hambre ha estado la gente por dejar la tierra, aunque no hay muchos indios que se hará este pueblo con comedio del Puerto de Caballos de la Mar del Norte y desde Fonseca de la Mar del Sur, y de un puerto a otro habrá cincuenta y cinco leguas, y de camino, que con poco trabajo y con la ayuda y merced que a vuestra Majestad enviamos a suplicar de veinte negros para los caminos, hará este y los demás para que se puedan andar con bestias y recuas cargadas. / Fol.2/ Que es la más principal parate del sostenimiento y bien de esta tierra. Suplico a vuestra Majestad, si no ha sido proveído lo mánde proveer...Desde que algunas provincias de Yucatán han sabido que yo era venido a esta tierra, han venido en canoas ciertos principales a verme para que les asegure sus rescates y contrataciones, lo que hata aqui no se solía hacer por la muerte de los cristianos que mataron en Puerto de Caballos, que fueron en ellos, ellos y otros de muchas partes, yo los envié muy contentos y seguros para que puedan venir a sus contratación al rió de Ulua, porque este era todo el trato que ellos tenían, y es gran bien para esta tierra, y les mandé que llamasen a todas las más provincias de aquella Comarca y creo que asi lo haran. Nuestro señor la vida e imperial estado de vuestra Majestad guarde y prospere con muchos más reynos y señoríos, como por vuestra Majestad, y por todos sus criados y vasallos es deseado. De éste pueblo de Naco de la Provincia de Higueras 28 de Julio de 1537 años. De vuestra Sacra Cesarea Catolica Majestad. Humilde vasallo y criado que las sacras manos de vuestra Majestad besa. El Adelantado Don Francisco de Montejo. "27

\section{CARTA A SU MAJESTAD DEL ADELANTADO DON FRANCISCO}

DE MONTEJO, Queja del mal tramiento que habia recibido del adelantado Pedro de Alvarado y del licenciado Cristobal de Pedraza, alzaminto de toda la tierra, muerte de cristianos, ezposión de la conducta y procedimientos de 1 adelantado Alvarado y Pedraza, despojo por el adelantado Alvarado de la

Gobernación de Honduras.

Montejo. 1539 SACRA CESAREA CATOLICA MAGESTAD. Por la vía de

\footnotetext{
${ }^{27}$ Fuente: AGI. AG, LEGAJO 9. AÑO DE 1537. (28 DE JULIO)
} 
México hé hecho larga relación a Vuesstra Majestad de las cosas de esta tiera, con el Bachiller Joan Alvarez, porque en este puerto no hé podido; que me tienen aquí cautivo, que por ningun parte me dejan hacer mensajeros; y esta carta envío al Puerto secretamente, si hallase algún marinero que la ose llevar. Sabra Vuestra Majestad que después de tener pacifica la tierra, y poblada en esta ciudad de Gracias a Dios y la villa de Comayagua, y reformada la vlla de San Pedro, y principiada la villa en el Puerto de Caballos, se revelo toda la tierra, y mataron ciertos cristianos, que no quedó ninguna cosa en toda la tierra que no se alzó, y duró la guerra dos años y en ella se han pasado grandes trabajos y muertes de españoles, como vuestra Magestad verá por la relación que envío a vuestra Magestad, por la vía de México, a que me remito, sin daño de pueblo de toda la tierra, y sin haber un esclavo en todo estos dos años. Estando al cabo de la pacificación de la tierra, llego Don Cristobal de Pedraza, Obispo, que dice que es, publicando que traía poder sobre mí, y indicando a todos que se quejasen a él; y metió tanto fuego en la tierra, que hubiera de ser la causa de despoblarla; y publicando que con una carta suya, vuestra Magestad, me quitaría esta gobernación, y otras muchas palabras y cosas feas, antes que llegase donde yo estaba, y llegado yo le hice hacer una casa, la primera que yo hice en esta tierra para mí, y le dí un pueblo de indios, una legua de esta ciudad, el mejor que yo tenía, y le hice el mejor recibimiento y obras que yo pude, y lo deje en esta ciudad y me fui a acabar de pacificar toda esta tierra, y asi lo hice; y antes que de allá viniese, deje descubiertas las más ricas minas de plata que hay en todas las indias, dos tiros de vallestas /Fol.1.v\% De la villa de Comayagua; y andando por allá, me vinieron a llamar con mucha prisa, que el Obispo revovía toda la tierra y crea Vuestra Majestad, que él no es hombe, sino enemigo, y el más rudo hombre para indios y cristianos que hay en el mundo y que peor trata; y llegado, hallé bien que apaciguar, y teniendo toda la tierra sosegada y de paz, llega el Adelantado Don Pedro de Alvarado al Puerto, de la manera que aqui diré. Llegado al Puerto con el Armada que dice que traía para la China, que según ha parecido no era más de para contra mia, publicando que traía esta gobernación y que le había mandado Vuestra Magestad que me enviase con unos grillos a España; y llegado a esa ciudad con toda su gente hechóme al Obispo, que me dijese que tenía muchas provisiones contra mí, y que la voluntad de vuestra Majestad, era de quitarme esta Gobernación y dársela a el dicho Adelantado Alvarado; y que me aconsejase que hiciesemos concierto, y asi encomenzó a entender en ellos; y porque no lo quise hacer como el quizo, hizo lo que aqui hago relación a Vuestra Majestad. Enviáme con su Procurador a notificar una provisión que Vuestra Magestad le mandó dar, que lo que él conquistó y pacifícó, y repartió y hubieron a las personas que los encomendó, que se volviesen a las personas que yo había quitado, como en la Provisión se contiene, a que me remito. Respondi que me mostrasen los títulos que cada uno tenía, que no lo cumpliría como Vuestra Majestad lo mandaba, y en dando yo esta respuesta, metióse el Obispo en ello, y hace sus procesos sin me oír, ni parte ninguna que tuviese posesión, ni sin mostrar Provisión por donde lo hacía, y procede en el negocio; y como yo lo supe, mandé dar un pregón que todas las personas que tuviesen título del Adelantado Alvarado, que viniesen ante mí, que yo les metería en la posesión, conforme a las provisiones de Vuestra Majestad, y no embargante, esto todavía Procedió y quiteme a mi todos los pueblos que tenía, y a todos los vecinos, y por dar uno un repartimiento, quito a diez vecinos que tenían en una provincia. 


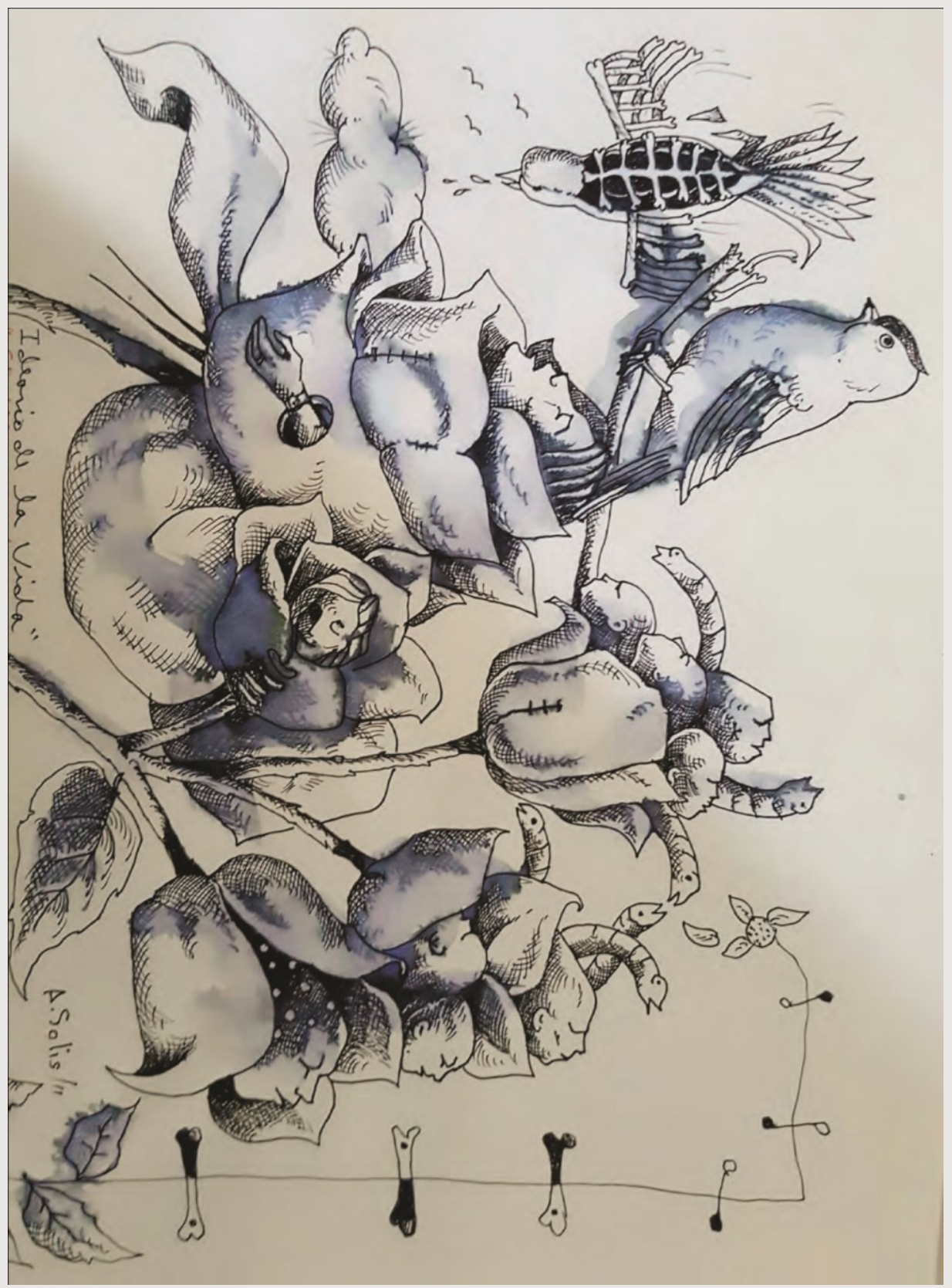

Armando Solis 
a ttres y a cuatro, sin haber ninguno de los que tenían la posesión, y todo esto por inducimiento del Adelantado Alvarado, y con favor de su Armada, y para venirme a notificar alguna pena que se ponía, traía el escribano veinte hombres armados de los del Adelantado; y al fin sin yo estorbarle ninguna cosa de lo que él quiso hacer, y habiendo yo respondido lo que el dicho me condenó, en pago de los muchos gastos que en esta tierra he hecho, y delos muchos trabajos que en ella he pasado por ponerla en estado que ahora está, que nunca tal se pensó, sin Vuestra Magestad se lo mandar, ni tener poder para ello, en privfación de oficios y perdimientos de bienes; y luego mandó a los oficiales de vuestra Magestad, que no me acudiesen por salario, ni otra cosa, y mandó a pregonar que ninguno me tuviese por gobernador, so grandes penas y antes sí, se hahecho y porque yo quise apregonar la provisión de/Fol.2./ Vuestra Majesta de la gobernación, envió por gente a el Adelantado Don Pedro de Alvarado, y envióle cien arcabucerros y métense la mitad en su casa, y la mitad en casa de un Alcalde que se llama Gónzalo de Alvarado, y los que conmigo estaban, como lo supieron, hubieron miedo, y el escribano y otros se fueron y me dejaron sólo, sin apregonarla y así me quedé sin gobernación, y con arto temor de la muerte. Los que en esto más ha metido la mano son el Tesorero Celis, y el Contador Cereceda, y el veedor Valdez, por amor de ellos. Como ya esta abezados a matar y desposeer gobernadores, fueron nombrados por gobenadores por el Obispo, Tesorero y Contador, y después acordaron a juntarse, y el Obispo y oficiales en Cabildo, y reciben a un Cava y a un Hernán Sanchez, por Regidores, habiendo falsado las provisiones de vuestra Majestad, y provándose averiguadose en cabildo, y recibidos todos juntos, reciben al Adelantado Don Pedro de Alvardo pro gobernador, y por tal lo apregonaro; y sobre ello han hecho muchas probanzas contra mí, espcialmente el Obispo; y juntándose el cabildo y Oficiales de vuestra Magestad, y mi Alcalde y un Regidor, primos del Adelanado Alvarado, y este Cava y Hernán Sánchez, que ya he dicho, que el uno es su pariente y el otro su mayordomo, y diz sobrinos del Obispo, y el escribano de cabildo, un paje del adelantado que con él se fue sirviendo de paje, vea Vuestra Magestad la información que estos pueden dar. Yo fui avisado que si nome concertba, que corria riezgo mi persona; y a esta causa yo hice el concierto que vuestra Magestad allá vera; y escribí juntament con él al Adelantado, una carta a Vuestra Majestad sobre ello; y digo que si vuestra Magestad fuere servido que el concierto pase, pues yo lo juré y prometí, y si cumple al servicio de Vuestra Magestad, que yo lo he por bien. Y asi lo suplico a Vuestra Magestad, mande no sean hechas las provisiones, porqu mi deseo no es sino de servir a Vuestra Magestad, que una cosa de tan grande desacato hecha a su gobernador y persona puesta en su nombre, no quede sin gran castigo; y más en tierra donde tantos se han ehcho, y tann poco temor tienen a Dios y a Vuestra Magestad, y en tan poco, que diciendo yo al Contador Cereceda, que por qué no me favorecian, respondió, que otras cosas más feas había el visto, y no eran castigadas; que tamvpoco se castigaría esta y otras cosas más feas y m's en deservicio de Vuestra Magestad. Que sobre toedo pido a vuestar Majestad, justicia, contra todos los que en estos han sido, y más de este Obispo; y así lo quedo esperando de Dios y de Vuestra Magestad. Demás de los pueblos del Adelantado, me quitó uno que llaman Ocotepeque, y por otro nombre EL ASISTENTE, que el adelantado Don Pedro de Alvarado, dio a un Joan García de 
Lemus, vecino de Guatemala, antes que a esta gobernación viniese, siendo gobernador de Guatemala, y dice la cédula, que lo dá de guerra, con tal que lo traíga de paz; y desde a /Fol.2.v'./Ocho meses que se lo encomendó vino el Adelantado Alvarodo a esta tierra, y el Joan García de Lemus no quiso venir con él, y alló el pueblo que digo, de guerra; así se la dio bien cruda, y hizo en ella muchos esclavos y como pueblo a quién dio guerra lo repartio en esta gobernció a Don Pedro de Calderón, el cual por desconteno de la tierra se fue al Perú, y yo por su ausencia lo tomé para mí, porque el Don Pedro Calderón no quizo venir a la pacificación de la tierra y se fue a donde tengo dicho. Y con ser esto así y con haber Vuestra Magestad hecho merced a esta gobernación, por su Real cédula, que todos los resparimientos que hizo el Adelantado Alvarado sirvan a esta Gobernación, no embargante, que haya sido repartidos en otras gobernaciones de Guatemala y León, y con estar esta cédula apregonada y en los libros de Cabildo, y viendo que la Real Provisión por donde se dice que es mejor ejecutor, no habla sino en los repartimientos que hizo el Adelantado Alvarado en esta Gobernación, se ha metido en ellos; y sin darme parte me condenó en el pueblo y en seiscientos castellanos de oro del maíz que ho alli he cojido, y sin notificármelo, ni a mero en posesión, y dió un mandamiento de secución y quedó en esta ciudad sin un indio, y sin un grano de maíz, con toda mi casa, ni donde lo haber, ni con que lo comprar. De todo pido justicia a vuestra Magestad. Lo que suplico a Vuestra Magestad, que pues que a mi no me dejan ir a pedir justicia, ni escribir, que vuestra Magesad, envie una persona que castigue estas cosas, y haga justicia a todos que es bien menester y vuestra Majestad, sabrá luego de la personal que viniere la verdad de todo. En tanto el temor que todos tiene a este Obispo de las crueldades que hace, que por cada palabra tiene a un hombre de caveza en un cepo, dos o tres días en su casa, en su recamara; y por qué un hidalgo muy hombre de bien, dijo, que le parecía mal, lo que hacía, lo tuvo tres dias en el cepo en su recamara, sin que hombre lo vió, ni comió bocado y cuando salió pareció que salió del otro mundo. El hace probanzas contra todos, con los escribanos criados del Adelantado como ha querido. Ha publicado que yo no obedesco las provisiones de vuestra Magestad; a las mismas provisiones me remito, hay tantas cosas que decir de él, de robos que hizo allá en Castilla, y acá, que porque vuestra Majestad los habrá sabido de mano de Guzmán a él yo me remito y a otras personas que de él se habran quejado, y las de acá, el que viniere las sabrá, y las crueldades que ha hecho con los indios que yo le encomendé, asi en tener cepo en el pueblo, y tenerlos cada día de caveza en él, como servirse de ellos y de las mujeres, lo que nunca nadie tal ha hecho en sus haciendas y granjerías, y en hacer casas y otras cosas que todos tienen que decir, de más de las cosas en que se mete que en lugar de Protector, es Gobernador, porque conoce de cautas cosas se ofrecen, asi de cuestiones, cmo de otras calidades; y la tenía como acá sabra la persona que viniese. /Fol.3./ Amañeado el Adelantado Don Pedro de Alvarado, y Obispo y los oficiales que todas las ciudades y villa, le den poder parque procure las cosas que convien a la tierra, y lleve el oro de vuestra Magestad, para que sea más creído de las falsedades que dijese y llleva ordenanzas; y a todos se ofrece que ha de negociar cosas particualares para atraerlos a a hecer sus informaciones falsas, como vuestra Majestad, allá verá. Y demás de esto, lleva a cargo de los negociso del Adelantado Don Pedro de Alvarado, sobre que se han fundado las cosas que ha hecho, 
porque se lo ha bien pagado el Adelantado, y ha hecho qe le presten los oficiales, dineros y otras personas para hacer su jornada. Aviso de todo a Vuestra Majestad, porque sobre todo provea lo que fuere más servido y porque espero la justicia y el remedio de Vuestra Majestad; y no se sí esta carta habra dicha de llegar, no me alargo a más. El factor Joan de Lermas, es el mayor servidor que vuestra Magestad tiene en esta tierra, y el que peor le ha parecido lo que ha hecho, y el que lo ha contradicho a sus compañeros y a todos los demás; y con todo cuanto ha trabajado no le ha aprovechado más que a mí. Suplico a Vuestra Majestad, por tal le tenga, porque él ha hecho como muy leal servidor de Vuestra Majestad. El Contador y Tesorero que han sido los de más en estos han metido mano, como ya he hecho relación a vuestras Magestad, las causasas que dan para echarme de la tierra; dicen que ellos bien conocen que yo he puesto la tierra en el esado que nunca se pensó y conocen que en ello he tenido b uena maña; pero que yo trato muy bien a los indios, y que no les doy lugar a que se aprovechen como ellos querían, que es en un año destruir toda la tiera como han ehcho los demás, y hacerse presto ricos y irse a Castilla; y que el Adelantado que les dá la ley más ancha, y otra razón que no tengo tanta posibilidad como el Adelntado Don Pedro de Alvarado, y no ven que los teimpos pasados onde he tenido toda la necesdiad que se podia tener que sin ningun socorro he puesto la tierra toda en paz y sociego y ahora que esta así, que no hay necesidad de ningun socorro, hallándome que no tengo posibilidad por destruir presto la tierra, ella estaba al tiempo que el Adelantado Don Pedro llegó, en tanto sosiego, que yo dab gracias a Dios por ello, y todos encomendaban a granjear y entender en sus haciendas, descubiertas muchas minas de oro y plata, y en muchas parte y la ciudad de Trujillo que estaba la cosa más perdida de todo el mundo, y en toda su prosperidad nunca se sacó oro; y desde que yo vine, está la mejor cosa de la tierra, y sacan oro todos a castellano, y castellano y medio, y a dos castellanos, por labrado, y ahora que yo pensaba /Fol.3.v. . I Tener algun descanso en pago de mis buenos servicios y obras me ha venodo este tan buen socorro para el remedio de mis ttrabajo y pérdidas. Suplico a Vuestra Majestad lo mande remedirar con brevedad todo. Nuestro Señor la vida e imperial estado de vuestra Magestad acreciente muchos mayores reynos y señorios, como los criados y vassallos de vuestra Majestad deseamos. De esta ciudad de Gracias a Dios a quince de agosto de mil quinientos y treinta y nueve años. De vuestra sacra cesarea catolica majestad, humilde criado y vasallo que las manos de vuestra majestad besa. El adealntado Montejo. "'28

24- 1543. El Licenciado Maldonado, informa a su majestad de su venida a Guatemala y de su relación, que no quisieron recibir a su teniente en la ciudad de Gracias a Dios, Honduras, porque por su provision se mandaba tuviese esta de Honduras con lo de Guatemala, y el Adelantado Montejo y Cabildo no lo recibieron. Entre tanto recibía

${ }^{28}$ AGI. AG.LEG.9. AÑO 1539.(15 DE AGOSTO ) 
respuesta del vissorey, se partió a visitar la villa de San Salvador, que es en la gobernación de Guatemala.

"Fol.1/. SACRA CESEAREA CATOLICA MAGESTAD. De México escribi a Vuestra Magestad mi venida a Guatemala y como llegué allí dí relación a Vuestra Magestad de algunas cosas lo que despúes a Dios y que Vuestra Magestad sepa, es que de Guatemala envié mi teniente a la Ciudad de Gracias a Dios, que es en esta Gobernación de Honduras, porque por mi provisión se mandaba tuviese ésta de Honduras con lo de Guatemala, y el adelantado Montejo y cabildo de aquella ciudad no le quisieron recibir , y a la Provisión Real y poder que yo dí, dieron cierta respueta como más largo por la sobre carta que aquella Real Audiencia a ello proveyó, parece que envió a Vuestra Magestad en él, entre tanto, que el teniente que envié a la Ciudad de Gracias a Dios, yo aguardé en Guatemala, aunque habia necesdiad de visitar algunos pueblos de aquella Gobernación, vista la respueta que en Gracias a Dios se dio ami teniente, despché para el Visorrey y aquella Real Audiencia todo para que proveyese lo que más convenía, y en el entretanto que de México volvía la respuesta de lo que se debía hacer en lo tocante a estas gobernaciones, me partí a la villa de San Salvador, que es en la gobernación de Guatemala a la visitar y por ver lagunas cosas que convenían al servicio de vuestra Magestad, llegda allí tuve nueva como Juan Pérez de Cabrera, habia venido proveído por gobernador de esta Gobernación, por provisión del Audiencia Real que reside en la ciudad de Santo Domingo, de la Isla Española y tampoco en la cudad de Gracias a Dios no le habian /Fol. 1.v\% Querido recibir y se había vuelto a esta Villa de San Pedro, para volverse con gente de la que habia traido y hacerse recibir favorablemente, y pareciéndome que no hera bien que hubiese el menor escándalo de lo que decian, se esperaran por evitarlos, me partí para la ciudad de Gracias a Dios, que esta veinte y cinco leguas de aquella Villa, llegado allí, tuve nueva que Juan Pérez de Cabrera, no volvió de la manera que se había dicho, ants había pasado a Trujillo, como aquello vide, me parti de alli para la villa de San Miguel, que es en la gobernación de Guatemala, a la vistiar y dar orden en algunas cosas que convenían hasta ver la respuesta de lo que se proveía, vista a respuesta que al Teniente que envié a la Ciudad de Gracias a Dios, se habia dado estando allí, recibi sobre carta y provisión del Audiencia Real de la Nueva España, en que se me mandba, que sin embrgo de la respuesta que a mi teniente se dio, tenga estas gobernciones, juntamente conla de Guatemala, or todo una cosa como más largo por la provisión y sobre carta parece. Recibida esta segunda provisión, me artí para Gracias a Dios, y luego fui recibido en el Cabildo de aquella Ciudad, y envié a mis tenientes para las villas con provisión y en las villas de Comayagua y San Jorge del Valle de Olancho y Minas de Guayape, fui recibido y en esta villa de San Pedro no me quisieron recibir, diciendo que tenían recibido a Joan Pérez de Cabrera, por provisión del Audiencia Real de Santo Domingo, después de esto, me vine a esta Villa por verla y ver el Puerto de Caballos, y otro día después que llegue aquí, llegó Juan Pérez de Cabrera que estaba en Trujillo y hable conél, rogándole que dejase esta gobernación, pues la intención del Audiencia de Santo Domingo, era que no usase de su provisión estando otro proveído y recibido en ella, como por un capitulo de 
instrucción que el Presidente y Oidores de aquella Real Audiencia le habian dado, parecia que no lo quizo hacer, yo por escuzarlo todo escándalo, no hice otra cosa más de presentar mi Provisión y un requerimiento, cuyo traslado también envio a Vuestra Majestad, con la respuesta que se me dio y el capitulo de instrucción que se le dio a Juan Pérez de Cabrera, he dado a vuestra Magestad cuenta paa que sepa lo que acá ha pasado. En esta gobernación de Honduras que aún parece que no son acabadas las diferencias de gobernadores en ella, y porque ya cuando ésta llegue habra Vuestra Magestad mandado proveer lo que convenga a esa gobernación y a la de Guatemala, no digo más en ellas.

Yo he visto toda esta gobernación y hay muy pocos indios en ella, que les han dadomás prisa de la aue convenía y así lo han apocado y si vuestra Magestad no manda a remediarlo se acbarán, y una de las cosas que convienen para esto es que vuestra Magestad mande abrir los caminos de Gracias a Dios a este Puerto de Caballos, y de Comayuagua al Puerto, y de las minas de Olancho al Puerto, porque en ír a la mar, se trabajan mucho y mueren muchos en ese camino, y esto no se puede hacer con indios, porque hay muy pocos, hay necesidad que vuestra Magestad haga merced de esta gobernación para este efecto, de cuarenta negros, que podran abrir los caminos y los oficiales de Vuestra Magestad tendran cuidado de estos negros, como de cosa de Vuestra Majestad y los venderan cuando se acabenlos caminos que se hrá en poco tiempo.

También hay mucha necesidad de abrir el camino de Guatemala a este Puerto de Cabllos y es cosa muy importante para aquella gobernción, y para esto, puesto se puede hacer con indios y teniendo la ciudad de Guatemala en su caveza los que ahora tiene, que vacaron por muerte del Adelantado Alvarado, tiene buen aparejo para ello, aunqeu ahora estan ocupados en hacer obras públicas de aquella ciudad y no conviene que Vuestra Magestad los mande quitar a la ciudad, hasta que esten acabadas algunas obras públicas de ella, y de esta manera, se edificará muy bien y ennoblecerá aquella ciudad y de todo loque rentan los pueblos y se gasta hay cuenta y razón y la enviaré a Vuestra Magestad como vuelva a Guatemala.

La memoria de los pueblos aque vacaron en Guatemala por muerte del Adelantado, ya vuestra Magestd tendrá alló, porque de México se envió a Vuestra Majestad antes de mi partida, los que en esta gobernción de Hondruas y Higueras, por su fin, vacaron, son estos: en términos de la ciudad de Gracias a Dios, los pueblos de Tencoa, y Yamala, y Posta. En términos de la villa de Comayagua, Tecosquin, Lexamani, Guazoza. En términos de la villa de San Pedro, Naco y Cocumba, estos se /Fol.2./ Repartieron por los gobernadores que el cabildo eligió, después de la muerte del Adelantado Alvarado, y estanse así, en las personas que los repartieron, que yo no he tocado. En ellos hasta saber lo que Vuestra Majestad manda que se haga en ello, y si Vuestra Magestad mandase que se aplicasen los que estan en términos de la Ciudad de Gracias a Dios a la misma ciudad, y los que están en términos de esta villa de San Pedro, a esta Villa, y los que están en términos de Comayagua a Comayagua, , para obras públicas y abrir los caminos, podrían se abrir muy bien, aunque todavía habría 
necesidad de veinte negros, porque como tengo dicho en esta gobernación hay pocos indios, para que entiendan en ello, y podrían se hacer algunas obras públicas. En esta Villa y en la ciudad de Gracias a Dios y Comayagua, que de todo hay mucha necesidad y como se acabase lo de los caminos y algunas obras públicas, podrá vuestra Majestad mandarlos proveer en las personas que fuese servido, y pues se ha hecho asi en Guatemala, no tendrían razón de desagraviar los de esta gobernación. Las minas de Olancho han aflojado algo, pero todavía se saca mucha cantidad de oro, saca Ada esclavo, medio eso por día y a ducado, hay mucha cantidad de negros, ya en ellas que serán hasta mil y quinientos, con los que allá hay, y están en ese puerto para irse, toda aquella tierra muy rica y aunque falta aquel río de Guyape, donde ahora lo sacan, hay ya descubiertos otros ríos y como entra cantidad de negros cada día, han de descubrirse más. Por relación que tengo de Francisco del Vasco, que es el que tiene poblada la villa de San Jorge, en aquel valle de Olancho, aquella tierra, es muy buena y muy rica de oro y muy apacible y muy sana, hay mucha caza en ella de venados, conejos y dantas en mucha cantidad, este valle es más apacible. /Fol.2.v\%

Según me escriben que se ha visto en estas partes, tiene este valle diez o doce leguas de largo, y en ancho tendrá cinco, entran cinco ríos en él, todos grandes y todos cinco en el mismo valle se juntan en uno hay muchas frutas y cacao, a tales en él, yo he estado algunas veces para irlo a ver y compensar cada día que vuestra Magestad, enviara persona aquí que tuviera esto no lo he hecho, como vuestra Magestad provea persona que lo tengo bien, creo a de ser aquello lo mejor de la gobernación, y que vuestra Magestad de por muy servido y aprovechando en aquella tierra. Gonzalo Ronquillo, veedor de Guatemala, murió en la Veracruz, yendo de camino para esos reynos a besar las manos de vuestra Magestad, yo provei en su lugar en el oficio de veedor hasta que vuestra Majestad mandase proveer otra cosa, a Alonso de Castillo Maldonado, que es uno de los tres que salieron de la Florida de la Campaña de Narvaez, ha servido a Vuestra Majestad en aquella tierra y en la Nueva España, en lo que se ha ofrecido. Suplico a Vuestra Magestad, sea servido de hacerle merced de aquel oficio, porque en él estará bien proveído y vuestra Merced le gratificará parte de lo que ha servido. Nuestro señor guarde a vuestra Magestad por muchos años con acrecentamiento de mayores reynos y señorios. De este Puerto de caballos, a 15 de enero de mil quinientos y cuarenta y tres años. De vuesta Sacra Católica Magestad Muy humilde servidor y criado que sus reales pies y manos besa.El Licenciado Maldonado" 29

\section{5. $15^{30}$ de enero de 1543. Maldonado, escribía a su Majestad, entre otras, la visita a San Salvador}

“...porque en ir a la mar se trabajan mucho y mueren muchos en este camino y este no se puede hacer con indios porque hay muy pocos hay necesidad de vuestra majestad haga merced a esta gobernación para este efecto de cuarenta negros que podrán abrir

\footnotetext{
${ }^{29}$ Fuente AGI.AUDIENCIA GUATEMALA.LEG.9 AÑO 1543.15 de enero

${ }^{30}$ Idem.
}

CUniversidad Tecnológica de El Salvador 
los caminos y los oficiales de vuestra majestad tendran cuidado de estos negros como de cosa de vuestra majestad y los venderan cuando se acaben los caminos que se hara en poco tiempo"30_(El subrayado es nuestro).

\section{CATALINA BERMUDES. 24 DE AGOSTO DE 1543. Esclavos negros}

"Fol. 207. EL PRINCIPE Nuestro Gobernador o juez de residencia de la Provincia de Guatemala e otras cualesquier nuestras justicias della a quien está mi cédula fuere mostrada, Alonso de San Juan en nombre de Catalina Bermudes, su padre legitimo había pasado a esa Provincia más había de catorce años e podria aver dos años que habia fallecido en esa Villa de San Salvador y dejado muchos negros esclavos, dineros, oro y plata e otras cosas en poder de Pero Núñez de Guzmán e Antonio Deocampo e de otras personas que a ello como a más provincia heredera le pertenecía todo aquello, suplicándome lo enviasedes a la casa de Contratación de las Indias, para q ue se acudiese con ello a quien pertenecia o como la mi merced fuese lo cual visto por los del nuestro Concejo de las Indias, fue acordado que debía mandar este mi cédula para vos en la dicha razón e yo tuvelo por bien porque vos mando que os informeis y sepais que oro e plata y otras cosas quedaron en esa tierra del dicho Antonio Bermudez y los saqueis de las personas en cuyo poder estuviere y juntamente con el testamento del dicho difunto si lo hizo e con otras cualesquier escrituras tocantes a los dichos bienes los enviad en los primeros navios que a estos reynos vengan dirigidos a los nuestros oficiales que residen en la ciudad de Sevilla en la Casa de Contratación de las Indias, para que de alli se acuda con ellos ala persona o personas que de derecho los hubiere de haber. E si alguna persona ante vos pareciere que pretenda tener derecho a los dichos bienes llamadas e vidas las partes haced sobre ello justicia. Fecha en Valladolid a XXII de agosto de mil quinientos e cuarenta e tres años. Yo el Principe, refrendada de Samano, señalada del Obispo de Cuenca y Bernal y Velásquez." ${ }_{31}$

\section{Enero 1546. Cabildo de San Salvador. Innovación leyes indias, libertada esclavos}

"Leyes Nuevas: 20 de noviembre de 1542. Barcelona. ${ }^{32}$

3 de enero de 1546. Carta del Cabildo de San Salvador a su Majestad, quejándose de las Leyes Nuevas._Quejandose sobre la libertad de los indigenas esclavos.

Nombramiento de Alonso de Oliveros, procurador solicita varias mercedes y título de Ciudad de San Salvador.

\footnotetext{
${ }^{31}$ AGI.AUDIENCIA GUATEMALA.LEG.9. AÑO 1543.15 de enero

32 "Leyes Nuevas: Fuente: Archivo General de Simancas. AGS. DC6-51[Dimensiones: 2 hs.
} 
"Muy poderoso señor. Biendo lo mucho que importa y la gran necesidad que hay de hacer este cabildo desta ciudad de San Salvador, relación a vuestra alteza del daño y perjuicio que a la dicha ciudad ha venido y biene para la perpetuidad y aumento de ella, en se haber proveido algunas cosas que se mandan guardar, como son dos cédulas, la una bedando los tamemes que habia de tasación entre los vecinos desta tierra y ansimismo, que con ningun indio de los naturales, se pueda aserrar madera y otra, que ninguno se sirva de indio ninguno, por vía de alquiler pareciendo a este cabildo que incurría en mucha culpa no haciendo a vuestra alteza relación, pues tanto, su majestad manda y encarga se edifiquen ciudades y villas en estas partes y se hagan buenos edificios que permanescan, hacemos saber a vuestra alteza que los dichos mandos son en mucho daño y disminución desta ciudad, señaladamente por estar como está fundada ochenta leguas del puerto y es el camino tan fragoso que por muchas partes no se puede un hombre a caballo ir sin que en haya agobio, sino con muy gran costa y trabajo de los naturales y no pudiendo como no se puede traer en tierras ningunas mercaderías quitando que los naturales no las traigan es en mucho daño desta ciudad y no podra permanecer.Sabra vuestra Alteza que esta ciudad, por estar como estaba asentada desde los principios en parte muy esteril y muy contrario a la perpetuidad della como ya creemos se ha hecho relación a vuestra Alteza, se mandó en asiento muy más provechoso y conveniente para que permanezca y se aumente, lo cual ha muy poco que se comenzo a edificar en ella y como en esta tierra no hay maestros, ni los materiales que en España, no se puede hacer nada, sino es con los naturales ayudándolos como se les ayuda con carretas y bueyes, hace puesto a los vecinos tanta estrechura en no darles igualdad que se edifique, quitándole el ayuda de los naturales, como se quita, que no se podrá hacer si vuestra alteza no lo remedia edificios que permanezcan como su majestad lo ha mandado, porque no pudiendo aserrar madera ni servirse de los naturales por vía de alquiler, como está mandado, no es posible poderse remediar de otra manera, porque en no haber esclavos ni negros y si alguno hay andan en las minas de oro y plata y sacarlos para las obras y edificios, sería en mucha disminución de las rentas de su majestad. Muchos viendo la buena disposición de la tierra y asiento deseando permanecer en ella, comenzaban a edificar en esta ciudad y poblar que no les sea hecho agravio ninguno y asimismo muchos vecinos a la mayor parte a causa de no tener, sino muy flacos repartimientos se ayudaban de lo mismo, lo cual en haberse quitado, ha cesado y muchas obras comenzadas no hay remedio, sino dexarlas perder y la ciudad berna en mucha disminución por no haber manera de poblar en ella ningun poblador, si vuestra alteza no lo remedia, rebocando los dichos mandos y favoreciendo a los vecinos y pobladores en que se ayuden de los naturales y no tanta estrechura, ni tasación en lo que tocare a edificar sus casas e hacer buenos edificios, pues lo ha ansi mando su majestad quién a vuestra Alteza ha hecho relación en que se quite y biese lo suso dicho, no tienen respeto al bien y perpetuidad y ennoblecimiento de la tierra, sino a mostrar que tiene cuidado de dar avisos, porque nos parece que a bien de venir a esta ciudad mucho daño, se les hace a los naturales mucho 
agravio en quitarles su libertad y con que se sustentan y pagan sus tributos. Asimismo sabra vuestra Alteza que en quitar los nabios que andan en la mar del sur, pereceran y no habra remedio de hacer otros ningunos por tanto a vuestra Alteza suplicamos lo mande ver y remediar y porque nuestro procurador Alonso de Oliberos en todo hara más cumplida relacion en lo que toca a su real servicio y bien de esta ciudad en esta no alargamos más nuestro señor prospere a vuestra alteza con acrecentamientos de mayores reynos, como vuestra alteza deseas, desta ciudad de San Salvador a tres de enero de mil quinientos cuarenta y seis años.Vasallos de vuestra Alteza. Luis Dubois, Alcalde, Francisco Cabezas, Juan de Medina, Lope Pardo, Bartolomé Bermúdez, Pedro Cerón, Francisco Castellano." 33

\section{8. "LA VILLA DE SAN SALVADOR, PARA QUE PUEDA ELEGIR ALGUACIL}

"EL PRINCIPE. Por cuanto Alonso de Oliveros en nombre de vos el Concejo, Justicia Regimiento de la Villa de San Salvador de la Provincia de Guatemala me ha sido hecha relación que al presente no hay por nos proveído Alguacil en esa dicha villa y me suplicó vos hiciese merced de os dar licencia y facultad para que vosotros los pudiésedes poner en una persona hábil y suficiente porque vosotros conoceréis e sabréis la persona que conviene para administrar el dicho oficio o como la mía merced fuese, e yo acatando lo suso dicho por la presente vos doy licencia e facultad para que podáis elegir e eligáis la persona que os pareciere que conviene para Alguacil de ella, de la dicha villa, y ansí elegido el nombramiento que hicieredes lo llevad ante el Presidente y oidores de la Audiencia Real de los Confines, para que ellos lo aprueben y si por ellos fuere aprobado, queremos e mandamos que la tal persona e que nos fuere por vosotros elegido y aprovado y confirmado por la dicha Audiencia sea alguacil de esa dicha Villa y use el dicho oficio en los casos e cosas a ella anexas e conciernientes por tiempo de cuatro años y más o menos por el tiempo que nuestra voluntad fuere. Fecha en Guadalajara a XXVII de septiembre de 1546 años. Yo el Principe, refrendada de Samano, señalada del Marques y Gutierrez, Velásquez e Gregorio López y Salieron y Doctor Hernan Pérez. "34

\section{9. “TITULO DE CIUDAD: VILLA DE SAN SALVADOR}

"Don Carlos. Etc. Por cuanto somos informado que en la Provincia de Cuzcatlán ay un pueblo que llaman Villa de San Salvador, el cual diz que está en sitio y tierra fértil e abundosa a donde acude mucha gente españoles e indios comarcanos e acatando esto tenemos voluntad que el dicho Pueblo se ennoblezca y otros pobladores se animen a ír a vivir a él e porque ansí nos lo suplicaron por su parte Alonso de Oliveros y Hernán Mendoza de Sotomayor, es nuestra merced e mandamos que ahora y de aquí

\footnotetext{
${ }^{33}$ Fuente: AG.AGI.Leg.43.

${ }^{34}$ Leg. 393. Libro 3. 1545-1551. Fol.22.1546,
} 
adelante se llame e institule Ciudad y que goce de las preeminencias, prerrogativas y inmunidades que puede y debe gozar por ser ciudad y encargamos al ilustrísimo principe Don Felipe, nuestrol muy caro y muy amado nieto e hñijo e mandamos al os infantes, duques prelados, marqueses, condes, ricos homes, maestre de las órdenes, priores e comendadores y subcomendadores, alcaldes de los castillo e casas fuertes e llanas e a los del nuestro Consejo, presidentes, Oidores de las nuestras Audiencias y Alcaldes de la nuestra casa e Corte e Chancillería e a todos los corregidores, gobernadores, alcaldes, alguaciles, veinticuatro regidores, caballeros e escuderos oficiales y hombres buenos de todas las ciudades, villas y lugares ansí destos mis reynos e señoríos, como de las nuestras Indias, Islas e Tierra Firme del mar océano, que guarden y cumplan e hagan guardar e cumplir lo en esta nuestra carta contenido e contra el tenor e forma dello, no vayan ni pasen, ni consientan ir, ni pasar en manera alguna, so pena de la mía merced e de veinte mil maravediz para la nuestra cámara. Dada en Guadalajara a 27 de septiembre de 1546 años. Yo el principe, Refrendada de Samano. Señalada del Marques y Gutierrez, Velásquez e Gregorio López e Salmero y Hernad Pérez." 35

\section{PRORROGA UN AÑO. 1547. ALONSO DE OLIVEROS}

"EL PRINCIPE. Por cuanto por parte de vos Alonso de Oliveros, vecino de la villa de San Salvador, que es en la Provincia de Guatemala, me ha sido hecha relación que vos veniste a estos reynos por parte general de la dicha Provincia a entender en las cosas que convenían al bien de ella yu que para poder venir travistes licecia de dos años del Presidente e Oidores de la Audiencia Real de los Confines, durante el cual dicho término, mandaron que nos fuesen quitados ni removidos los indios e otras granjerías que en la dicha Provincia teniades y que a causa de ir los negocios de aquella tierra a la larga y no se poder despachar brevemente, no podeis volver dentro del término que os fue dado y me suplicasteis os le mandase prorrogar por otro años más o como la mía merced fuere e Yo acatando los suso dicho y por vos hacer merced, tómelo por bien, por ende, por la presente vos prorrogamos e alargamos el término que ansi os fue dada por el dicho presidente e Oidores para venir a estos reynos y estar en ellos por otro año más, el cual corre y se cuente después de cumplido el término de los dichos dos años y mandamos al dicho Presidente e Oidores e a otras cualesquier justicias de la dicha Provincia de Guatemala, que durante el término desta prrrogación, no vos quiten ni remuevan los indios y otras granjerías que en la dicha Provincia tuvieredes. Fecha en Moncon de Aragón a primero de octubre de mil quinientos cuarenta y siete años. Yo el Principe. Refrendada de Samano. Señalada de Gutierres, Velásquez e Gregorio López e Salmerón y Hernán Pérez." ${ }^{36}$

\footnotetext{
${ }^{35}$ Fuente:Leg. 393. Libro 3. 1545-1551. Fol Fol.22 $v^{o}$.-...1546,

${ }^{36}$ Fuente Leg. 393. Libro 3. Fol. 67.
} 


\section{1. "LA CIUDAD DE SAN SALVADOR. 1 de octubre de 1547. HOSPITAL}

\section{EL PRINCIPE.}

Presidente e Oidores de la Audiencia Real de los Confines, Alonso de Oliveros en nombre de la ciudad de San Salvador me ha hecho relación que a causa de no haber en ella hospital, muchos pobres se mueren por no se curar e que como la dicha ciudad es nuevamente fundada y no tener como no tiene ningunos propios con que hacer el dicho Hospital e otrs cosas necesarias para la población della y por ser como es cosa muy importante a nuestro servicio, que permanezca y vaya aumento, me suplicó, mandase que diese para ello alguna cantidad de dinero para que los pobres sean recibidos y curados, conforme a lo que mandamos hacer e se hizo en la ciudades de Santo Domingo, Gracias a Dios o como la mía merced fuese, lo cual visto por los del Concejo de las Indias de su Majestad, fue acorado que debía mandar dar esta mí cédula para que vos e yo tuvelo por bien por que vos mando que veáis lo suso dicho y nos informéis de la necesidad que hay en la dicha ciudad de San Salvador, de que haya en ella un Hospital en que se acojan y curen los pobres y enfermos que en aquella tierra hubiera para que visto se provea sobre ello lo que más convenga al servicio de Dios nuestro Señor y mío y población y acrecentamiento de la dicha Ciudad. Fecha en Morón de Aragón a primero día del mes de octubre de mil quinientos cuarenta y siete años. Yo el Principe. Refrendada de Samano, señalada de Gutiérrez, Velásquez, Gregorio López e Salieron y Hernan Pérez." ${ }^{37}$

\section{2. "1 de octubre de 1547. CIUDAD DE SAN SALVADOR.TERMINOS Y EJIDOS}

"EL PRINCIPE. Licenciado Cerrato, presidente de la Audiencia Real de los Confines, Alonso Oliveros, en nombre de la Ciudad de San Salvador, me ha hecho relación que ha poco tiempo que la dicha ciudad esta asentada en el sitio donde agora esta y que no tiene término señalado para que los vecinos della puedan hacer sus heredades y haciendas y traer sus ganados, como lo suelen tener las otras ciudades que están bien edificadas e me suplicó, mandase señalar términos y ejidos competentes e que los vecinos planten y hagan sus heredades y granjerías, como la mía merced fuese, lo cual visto por los del Concejo Real de las Indias de su Majestad, fue acordado que debia mandar dar esta mi cédula para vos e Yo túvelo por bien por que vos mando que veáis lo sudo dicho y proveáis en ello lo que vieredes que más conviene, sin perjuicio de ningún tercero. Fecha en Morón de Aragón a primero de octubre de mil quinientos y

${ }^{37}$ Fuente:.AGI, Leg.393. Fol. 58-58v ${ }^{\circ}$ 
cuarenta y siete años. Yo el Principe. Refrendada de Samano, señalada de los dichos. "38

\section{R.C. PARA ALONSO DE OLIVEROS.1 de Septiembre de 1548. RENTA PARA PROPIOS}

\section{"LAS CIUDADES DE SANTIAGO Y SAN SALVADOR, SOBRE LOS PROPIOS.} "EL PRINCIPE.Licenciado Cerrato, Presidente de la Audiencia de los Confines, Alonso de Oliveros, en nombre de la ciudades de Santiago y San Salvador, de la Provincia de Guatemala, me ha hecho relación que las dichas ciudades, no tienen propios ni rentas algunas para obras públicas e otras cosas necesarias y me suplicó en el dicho nombre que pues las dichas ciudades eran las más principales de toda aquella provincia, vos mandase que en repartimiento perpetuo que habéis de hacer en aquella provincia, tuvieredes reparo a dejar y señalar algunas rentas para propios de las dichas ciudades o como la mía merced fuese e yo acatando los suso dicho helo habido por bien por ende yo vos mando que en el repartimiento general que avéis de hacer en la dicha Provincia, conforme a lo que está mandado por nos, está mandado tengaís consideración de dejar algunas rentas para propios de las dichas ciudades. Fecha en la Villa de Valladolid a primero días del mes de septiembre de mil quinientos y cuarenta y ocho años. Yo El Principe. Refrendada de Juan de Samabno y señalada del Marques y de Gutiérrez, Velásquez y Gregorio López y Sandoval y Hernán Pérez"'39

\section{7 de Mayo de 1548.- Juan Alonso de Oliveros (De Oliveros, Sevilla) conocía el tráfico y venta de esclavos en Sevilla. De Guatemala- pasar 8 esclavos}

Sevilla a mediados del siglo XVI será la ciudad con la mayor actividad social, económica, política y cultural, centro del comercio indiano, agregado Portugal, con tráfico de esclavos con África. Encomendero del pueblo de Oloquilta, ciento setenta casas, pocas más o menos, y que tiene la mitad del pueblo de Xocoyuco en los Chontales, provincia de San Salvador. Para pasar ciertos esclavos de quien su poder hubiere.

"El Príncipe. Por cuanto nos mandamos dar e dimos una nuestra cedula por la cual dimos licencia vos Alonso de Oliveros para pasar a las indias, ocho esclavos negros, habiendo primeramente pagado a Alvaro de Encinas, cambio en esta corte, los dos ducados de la licencia de cada uno de ellos, segun por ella parece, su tenor de la cual es este que se sigue: El príncipe por la presente doy licencia y facultad a vos Alonso de Oliveros para que de estos reinos e señorios podais

\footnotetext{
${ }^{38}$ Fuente: AGI. Leg..393. Fol.68v .39

Fuente:Leg..393. Fol.87V .
}

(C) Universidad Tecnológica de El Salvador 
pasar y paseis a las indias, islas e tierra firme del mar océano, ocho esclavos negros para servicio de vuestra persona e casa, yendo vos en persona a las dichas indias e no de otra manera e habiendo primeramente pagado a Alvaro de Encinas cambio en esta corte los dos ducados de la licencia de cada uno de ellos, por cuanto es de nos mandado tiene cargo de los cobrar e mandamos a los oficiales de las islas e provincias de las dichas indias donde los, dichos esclavos se llevaren, que tomen e non poder esta cedula original y la ponga en el arca de las tres llaves que ellos tienen, para que por virtud de ella, no se puedan pasar más de una vez los dichos esclavos, que para por esta vez damos licencia, fecha en la villa de Madrid a veinte y seis días del mes de octubre de mil quinientos cuarenta y seis años. Yo el príncipe por mandado de su alteza. Juan de Samano. E ahora por parte de vos el dicho Alonso de Oliveros me ha sido hecha relación que a causa de ha mucho tiempo que venistes de las indias a estos reinos a procurar los negocios de la provincia de Guatemala estais muy desgastado y no teneis con que al presente comprar los dichos esclavos e me suplicastes, que pues vos habrá de pagar los dos ducados de la fianza de cada uno de los dichos esclavos, vos hiciese merced de tener por bien, que los pudiese pasar otro en vuestro lugar y porque podría ser que después e vuelto vos a aquella tierra enviasedes dinero e con que comprasen los dichos esclavos y se cobrasen y como mi merced fuese e por voz hacer merced e que por nos ha consultado que pagastes al dicho Alvaro de Encinas los dos ducados de la licencia de cada uno dellos dichos esclavos e lo habido por bien por ende por la presente doy licencia e facultad a vos el dicho Alonso de Oliveros para que por virtud de esta mi cedula vos o quien vuestro poder quisiere podais pasar e paseis a las indias los dichos ocho esclavos en la dicha cedula suso incorporada contenidos por cuanto la original queda rasgada en poder de Juan de Samano secretario de su majestad e mandamos a los oficiales de las islas e provincias donde los dichos esclavos se llevaren que tomen en su poder esta cedula original e la pongan en el arca de las tres llaves que ellos tienen para que por virtud de ella no se puedan pasar dichos esclavos más de una vez. Fecha en la villa de Valladolid a siete días del mes de mayo de mil e quinientos de cuarenta y ocho años Yo el príncipe Refrendada de Juan de Samano e señalada de los dichos "39

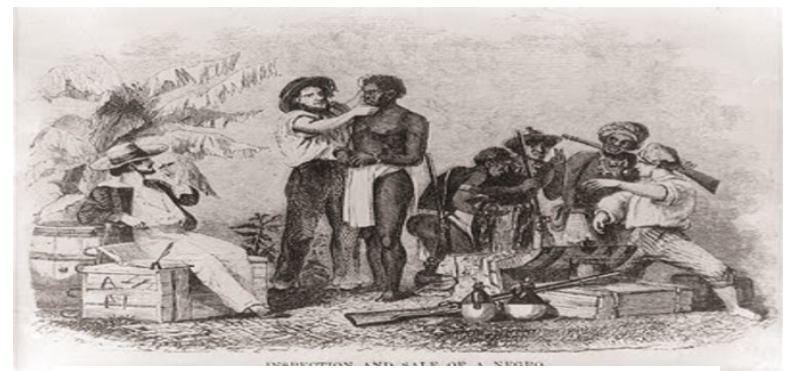

Fuente: Imágenes.cienciassocialesacs.blogspot.com.

${ }^{39}$ fuente: Archivo General de Indias,INDIFERENTE,424,L.21,F.160R - 1 - Imagen Núm: ES.41091.AGI/23.15.2031//INDIFERENTE,1964,L.10,F.112 


\section{R.C. Alonso de Oliveros.1 de octubre de 1548. Prorrogar el dicho término de los dichos dos años por otro año más-}

"EL PRINCIPE Por cuanto nos mandamos dar e dimos una nuestra cédula firmada de mi mano y refrendada de Joan de Samano, secretario de su majestad según por ella parecía su tenor de la cual es este que sigue: está asentada en este libro a primero de octubre de 1547 años. E agora la parte del dicho Alonso de Oliveros me ha sido hecha relación que vos no habéis podido, ni podéis volver a la dicha Provincia de Guatemala, dentro del término de la dicha nuestra cédula suso incorporada e contenido por estar como estáis en esta, entendiendo en los negocios de la República de la dicha Provincia, que eran de la importancia que nos hera notorio e me fue suplicado vos hiciese merced de prorrogar el dicho término de los dichos dos años por otro año más o como la mi merced fuere e yo acatándolo suso dicho e por vos hacer merced tuvelo po bien por ende por la presente vos prorrogo e alargo el término de un año con acuerdo en la dicha nuestra cédula suso incorporada por el dicho año más, el cual corra y se cuente después de cumplido el dicho un año en la dicha nuestra cédula e mandamos al Presidente e Oidores de la dicha Real Audiencia de los Confines e otras cualquier nuestras justicias della, que volviendo vos dentro del dicho término de esta prorrogación, no vos quiten ni remuevan los indios e otras granjerías que en aquella tierra dejasteis al tiempo de vuestra partida e si por vuestra ausencia os los hubieren quitado o removidos, os los vuelvan e restituyan e hagan volver y restituir. Fecha en la villa de Valladolid a primero día del mes de octubre de mil quinientos y cuarenta y ocho años. Yo el Príncipe, refrendada de Sámano y señalada del Marques Gutiérrez y Velásquez, Gregorio López y Sandoval y Hernán Pérez." 40

En la ciudad de San Salvador, el presidente López de Cerrato fue contundente al aplicar la legislación, ordena poner en libertad a los indios que tenían los vecinos encomenderos como esclavos, sin justos títulos y que ellos mismos reconocieron que fueron mal hechos y todos tomados de sus encomiendas, aunque responsabilizan de ello a los anteriores gobernadores por permitirles dicha práctica. De 40 vecinos que había en la ciudad, tenían 500 esclavos, además se efectuaron nuevas tasaciones de los tributos que los indígenas entregaban a los encomenderos. Asimismo, se hicieron las tasaciones de Nicaragua porque tendían el número de indios que había en cada pueblo, y que recientemente había realizado el Licenciado Ramírez.

36. El 9 de Abril de 1549, el presidente Cerrato también hizo la tasación del pueblo de Caluco, denominado también por Izalco de Xirón, el pueblo según la tasación tenía 400 tributarios, quedan tasados en entregar a su encomendero. Encomenderos Caluco y Tecpan Izalco 1549.

${ }^{40}$ Fuente: Leg..393.Fol.95. 


\begin{tabular}{|l|l|l|}
\hline Pedro Cerón. & $\begin{array}{l}\text { Caluco: } 400 \text { tributarios. } \\
\text { El 9 de Abril de 1549. }\end{array}$ & 1.000 xiquipiles de cacao. \\
\hline Juan de Guzmán. & Tecpan Izalco. & $\begin{array}{l}\text { Paga de tributo lo mismo que Caluco. } \\
\text { Rebaja tributo. }\end{array}$ \\
\hline
\end{tabular}

Cuadro No 3 Caluco, Izalco.34 Paga de tributo. Caluco.

\begin{tabular}{|c|c|c|}
\hline Encomendero: & $\begin{array}{l}\text { "Caluco: } 400 \text { tributarios. } 1549 . \\
\text { (Izalco de Xiron). }\end{array}$ & Tributos. \\
\hline $\begin{array}{l}\text { Gómez Díaz de la } \\
\text { Reguera, natural de } \\
\text { Astorga, } \\
\text { hijodalgo, de solar } \\
\text { conocido, llego a la } \\
\text { provincia de San } \\
\text { Salvador en 1534, } \\
\text { casado con Isabel } \\
\text { Costilla, hija mestiza de } \\
\text { Gaspar de Cepeda, } \\
\text { c o n q u is t a d o r - } \\
\text { encomendero de } \\
\text { Nahuizalco, Citalá y } \\
\text { Guazapa. }\end{array}$ & $\begin{array}{l}\text { Naulingo, } \\
\text { encomendero de Nahulingo, por } \\
\text { breve espacio de tiempo, pero } \\
\text { como comerciante, tenía estancia } \\
\text { y cacaotal cercano al pueblo de } \\
\text { encomienda, poderoso vecino de } \\
\text { la ciudad de San Salvador, con } \\
\text { intereses en los Izalcos, } \\
\text { emprenderá una larga cruzada } \\
\text { contra Juan de Guzmán y Diego } \\
\text { de Guzmán y otros encomenderos } \\
\text { de los otros pueblos de Izalcos, } \\
\text { Mejía beneficio a Reguera con las } \\
\text { tasaciones de sus pueblos, } \\
\text { recibiendocuantiosos obsequios, } \\
\text { agregado, ciertos intereses sobre } \\
\text { casar al doctor Mejía, con la hija } \\
\text { de Luisa Corvera y } 12 \text { mil pesos } \\
\text { de dote, que había de entregar, } \\
\text { Gómez Díaz de la Reguera. Los } \\
\text { bajos sueldos de los oidores } \\
\text { dieron paso a la corrupción. }\end{array}$ & $\begin{array}{l}\text { La mitad de los tributos } \\
\text { compartido con Juan de } \\
\text { Guzmán y Francisco López. }\end{array}$ \\
\hline
\end{tabular}




\begin{tabular}{|c|c|c|}
\hline 1- Pedro Cerón. & $\begin{array}{l}\text { Caluco. } \\
400 \text { tributarios. } 1549 .\end{array}$ & $\begin{array}{l}1.000 \text { xiquipiles de cacao. } \\
-10 \text { docenas de } \\
\text { Gallinas de Castilla al año, } \\
\text { mitad por san Juan y la otra } \\
\text { por Navidad, puestos en el } \\
\text { pueblo. } \\
\text {-le beneficien los } \\
\text { cacaotales } \\
\text { encomendero tres } \\
\text { veces al año } \\
\text {-50 hombres por } 2 \text { días, } \\
\text { con la obligación de darles } \\
\text { de comer. } \\
\text { Se rebaja el tributo: }\end{array}$ \\
\hline 2-Juan de Guzmán & $\begin{array}{l}\text { Tecpan del } \\
\text { Rebaja tributo. } \\
\text { (Izalco de Xiron). }\end{array}$ & $\begin{array}{l}\text { - número de mantas. } \\
\text { - maíz. } \\
\text { - Cera. - Miel. } \\
\text {-Gallinas de Castilla. } \\
\text {-Sal"1 }\end{array}$ \\
\hline
\end{tabular}

Cuadro $N^{\circ} 4$ Paga de tributo. Caluco.

La carta-relación escrita por el presidente Cerrato al Monarca el 8 de abril de 1549, deja ver con claridad la presión que están ejerciendo los encomenderos sobre su persona, por hacer cumplir las Leyes Nuevas, pues en el Distrito de la Audiencia, no se ponía en práctica ninguna ley, ordenanza ni provisión, pues se ignoraban o no se aplicaban, pues el presidente Maldonado, sus hermanos, cuñados y suegro tenían indios en encomienda, los tributos eran excesivos:

"los encomenderos de San Salvador y otras provincias, llevan lo que quieren y aunque mataran, robaran y esclavizaran a los indios, no había castigo para ningún español, los indios eran cargados como "tamemes" y los indios de encomienda eran empleados en labores de las minas, arrendando o alquilando a los mismos entre los encomenderos, todo en contra de lo proveído por la Corona." ${ }^{41}$

Cerrato no duda en denunciar que no se cumplió la ley de poner en libertad los indios que no fueron bien hechos esclavos, y no se platicó, ni mencionó en la Audiencia. (El subrayado es nuestro). La explotación de los recursos naturales y del subsuelo, movía a

\footnotetext{
${ }^{41}$ Fuentes: AGI.AG.Leg. 9.
} 
todos los intereses personales de los mal pagados funcionarios, mineros y encomenderos e la explotación de las minas, además del indio, se emplea mano de obra obligada africana y Cerrato así lo denuncia, pues Maldonado tenía sus cuadrillas de negros. El oidor Licenciado Herrera, había tomado a la fuerza una mina a un clérigo y había obtenido más de 7.000 mil castellanos de oro, más el título de 40 negros que también confisco. En San Salvador, los encomenderos tenían gran cantidad de esclavos sin justos títulos, el obispo había ordenado no perdonar a los esclavistas y procedió a ponerlos en libertad, pide sean castigados algunos encomenderos por los excesos cometidos. Por no guardar las Leyes, así de tamemes como de indios en alquiler y como es cosa nueva para ellos y dura, pues allí nunca se vio ni oyó tal, les parece excesiva, por lo que recurrirán a la corte. López de Cerrato advierte al Rey, que él no se ha excedido en ningún punto de la Ley, sino es cumplir con lo que tiene legislado, poniendo templanza y piedad, pero los encomenderos no quieren ninguna Ley que les impida la continuidad de sus privilegios y excesos, que no siguen otro provecho que enfados, pasiones y quejas contra su persona en la Corte.

Juan Alonso López de Cerrato, el recto presidente, no duda en puntualizar en su denuncia la grave especulación que los mismos españoles habían provocado, entre ellos, la falta de indígenas, pues antes habían muchos más, agregado que 10 tributarios debían de dar por 100, una carga de cacao valía 3 reales en la actualidad vale 80 o 90 reales, una manta, un real, su precio es 20 reales, la devaluación de la moneda es un hecho, pues 1.000 reales de esta equivalen 1000 pesos. Los encomenderos empeñados en obtener buenos beneficios de los indios y tratarlos a su voluntad, se quejan contra el recto funcionario real, que no duda en denunciar:

“...tengo por cierto que han de decir de allá herejías y plagíneses, a Dios que dijeren lo que hay que yo se lo agrande, si porque como a robadores yo no he cedido un punto de lo que vuestra majestad y sus leyes manda, pero yo sé que dirán cosas que espantan allá las sienes, porque como otras veces envio escrito a vuestra majestad, no hay en estas Indias cosa más odiosa como querer cumplir lo que vuestra Majestad manda, especialmente, si es en perjuicio de sus intereses, van muchos casados a España muy quejosos de mi por hacerles ir" "43

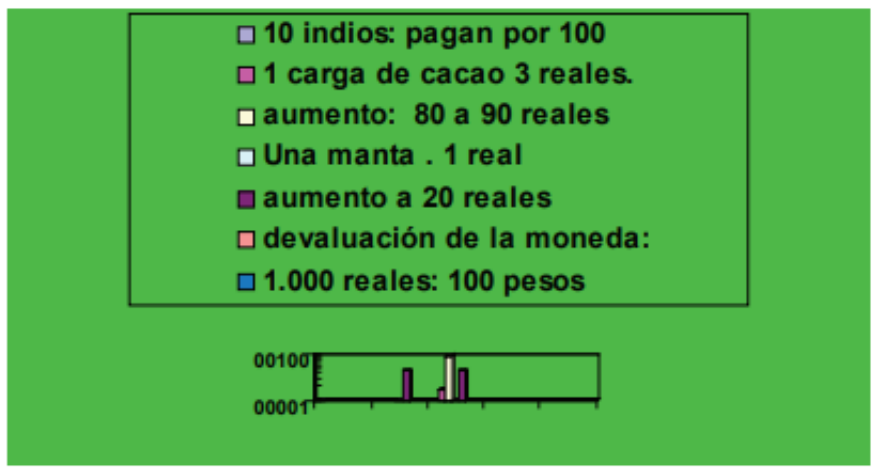

Gráfico 1 Especulación creada por los españoles.

(C) Unıversidad l'ecnologica de Ė Salvador 


\section{El dia 10 de junio 1549- se da una real cédula para que Juan Alonso Oliveros, pueda pasar a la nueva España:}

\section{"Real Cédula a los oficiales de la Casa de la Contratación para que dejen pasar a Nueva España a Juan Alonso de Oliveros." ${ }_{42}$}

38. "25 de OCTUBRE de 1549. "PERO NUÑEZ DE GUZMAN. LICENCIA PARA VENIR A ESTOS REYNOS. "EL REY. Presidente e Oidores de la nuestra Audiencia Real de los Confines, por parte de Pero Nuñez de Guzmán, vecino de la villa de San Salvador de la Provincia de Guatemala, me ha sido hecha relación que ha mucho tiempo que reside en la dicha Provincia, donde ha servido en lo que se ha ofrecido y que ahora tiene necesidad de venir a estos reynos a cosas ue le convienen y me fue suplicado le mandase dar licencia para ello por término de dos años y que durante el tiempo no le fuesen quitados ni removidos los indios e otras granjerías que tenía e como la mía merced fuese por ende yo vos mando que dejando el dicho Pero Nuñez de Guzmán en su lugar persona que convena e cumpla las cargas a q ue es obligado le déis licencia e facultad que nos por la presente le damos para que por término de dos años que corran y se cuenten desde el día que partiere e esa tiera adelante, pueda venir a estos reynos y estar en ellos y durante el dicho tiempo, no consistáis ni déis lugar que le sean quitados ni removidos los indos e otras granjerías que les tuviere encomendad obligándose y dando fianzas que dentro del dicho término, volverá a la dicha Provincia de Guatemala, donde no que entregará a los nuestros oficiales de ella, todo los tributos que hubieren habido de los dichos indios y granjerías durante el dicho tiempo y lo pagaran por sus personas e obligación e mando a los dichos nuestros oficiales que ponga en el arca de tres llaves que elos tienen en obligación e fianza que asi otorgare y que tenga cuidado del cumplimiento de lo en el término de la presente. Fecha en la villa de AGales a 25 días del mes de octubre de mil quinientos e cuarenta e nueva años. Su Majestad. Refrendada de Samano, señalada del Conde Gutiérrez, Velásquez, Gregorio López Tello, de Sandoval Ribadeneyra Birbiesca." 45

\section{Año 1550}

\section{1 de Marzo 1550. Real Cédula para ALONSO DE OLIVEROS prorroga de un año estancia en la corte}

"Prorrogación de un año estancia en la corte, para Alonso de Oliveros. Por cuanto yo mandé dar y dí una mi cédula, firmada del serenisismo principe Don Felipe, nuestro muy caro y muy amado hijo y nieto y refrendada de Joan de Samano, nuestro secretario, fecha en Estaguija. El príncipe, por cuanto nos mandamos dar y dimos una nuestra cédula firmada de mi mano y refrendada de Joan Samano, secretario de su Majestad,

42 Fuente: "Licencia de pasajeros a Juan Alonso de Oliveros" Archivo: Archivo General de Indias Signatura: INDIFERENTE, 1964,L.11,F.303V. 45 Fuente: Leg..393.Fol.125vº. Libro 3.

(C) Universidad Tecnológica de El Salvador 
según por ella parecía su tenor de la cédula es este que se sigue: El Principe. Por cuanto por parte de nos Alonso de Oliveros, vecino de la villa de San Salvador, que es en la provincia de Guatemala, me ha sido hecha relación, que vos venistes a estos reynos, por Procurador General de la dicha Provincia a entender en las cosas que convenían al bien de ella y que para poder venir, trajistes licencia de dos años del presidente y Oidores de la Audiencia Real de los Confines, durante el cual dicho término mandaron que nos os fuere quitados ni removidos los indios y otras granjerías que en la dicha provincia teníades y que a causa de ir los negocios de aquella tierra a la larga y no se poder despachar brevemente, no podéis volver dentro del término que os fue dado y me suplicastes os lo mandase prorrogar por otro año o como la mia merced fuese e yo acatando lo suso dicho y por vos hacer merced, tuvelo por bien, por ende por la presente, os prorrogamos e alargamos el término que ansi os fue dado por el dicho Presidente y Oidores, para venir a estos reynos y estar en ellos, por otro año más, el cual corra y se cuente después de cumplido el término de los dichos dos años y mandamos al dicho Presidente y Oidores y otras cualesquier justicias de la dicha Provincia de Guatemala, que durante el término de esta prorrogación, no vos quiten ni remueban los indios y otras granjerías que en la dicha provincia tuvieredes. Fecha en Mozon de Aragón a primero de octubre de mil y quinientos y cuarenta y siete años. Yo El Principe, por mando de su alteza, Juan de Samano. E agora por parte de vos Alonso de Oliveros, me ha sido hecha relación, que vos, no habéis podido ni podéis volver a la dicha provincia de Guatemala, dentro del término en la dicha nuestra cédula, suso incorporada contenido, por estar como estáis, en esta Corte, entendiendo en los negocios de la República de la dicha provincia, que eran de la importancia que nos era notorio y me fue suplicado vos hiciese merced de prorrogar el dicho término de los dichos dos años, por otro año más o como la mi merced fuese e yo acatando lo sudo dicho por vos, hacer merced, tuvelo por bien, por ende por la presente, vos prorrrogo y alargo el término de un año contenido en la dicha nuestra cédula suso incorporada, por el dicho año más, el cual corra y se cuente después de cumplido el dicho un año en la dicha vuestra cédula contenido y mandamos al Presidente y Oidores de la dicha Audiencia Real de los Confines y otras cualesquier nuestras justicias de ella que volviendo vos dentro del dicho término de esta prorrogación, no vos quiten ni remueban los indios y otras granjerías, que en aquella tierra dejasteis al tiempo de uestras partida e si por vuestra ausencia os las oviere quitado o removido, os las vuelvan y restituyan $y$ hagan volver y restituir. Fecha en la villa de Valladolid a primero día del mes de octubre de mil y quinientos y cuarenta y ocho años. Yo El Principe. Por mandado de su Alteza, Joan de Samano. Y ahora por parte de vos, el dicho Alonso Oliveros, me ha sido hecha relación que hasta ahora no havéis podido acabar los negocios a que venistes del a dicha provincia y ahora nuevamente os escribe la dicha provincia que volváis a esta Corte a entender en ellos y os comenten otros, además de los que venistes y a esta causa, vos no aveis podido ni podéis volver aquella tierra dentro del término del dicho un año en la dicha prorrogación suso incorporada contenido y me fue suplicado, os hiciese merced de prorrogarse por otro año y como la mi merced fuese e yo acatando lo suso dicho y por vos hacer merced, he avido y

CUniversidad Tecnológica de El Salvador 


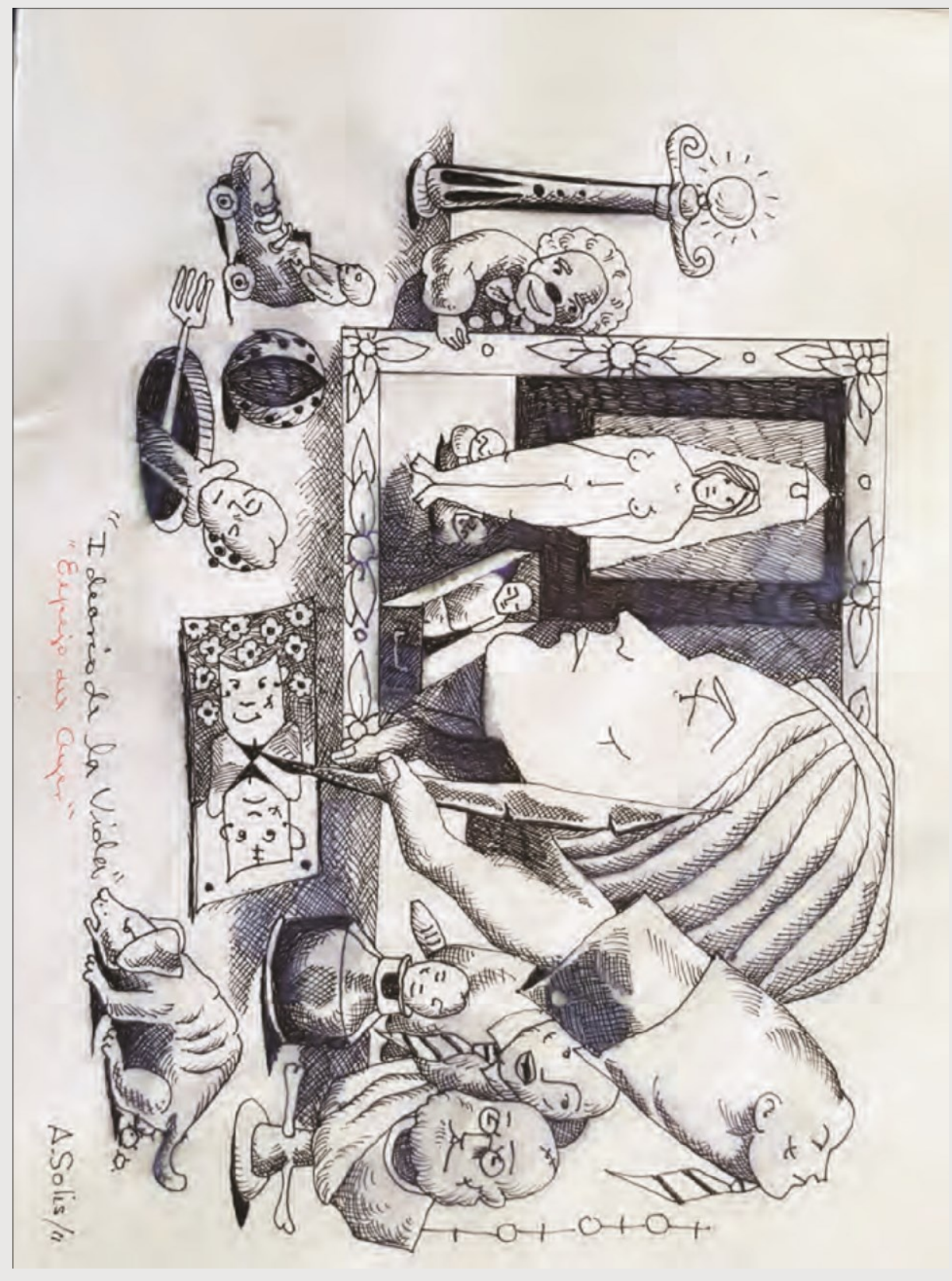

Armando Solis 
tengo por bien de prorrogarlos el término de prorrogación del dicho un año en la dicha cédula de suso incorporada contenido, por todo este año de quinientos y cincuenta, con que en todo el dicho año os volvais a la dicha Provincia de Guatimala y mandamos al Presidente y Oidores de la dicha Audiencia Real de los Confines y a otras cualesquier nuestras justicias della, que volviendo vos a aquella tierra en todo este dicho año de quinientos y cincuenta, no vos quiten ni remuevan los indios e otras granjerías que en ella dejastes, al tiempo de vuestra partida e si por vuestra ausencia os las ovieren quitado y removido, os los vuelvan y restituyan y hagan volver y restituir. Fecha en la villa de Valladolid a once días del mes de marzo de mil y quinientos y cincuenta años. Maximiliano. La Reyna. Refrendada de Samano y señalada del marques y Gutiérrez y Velásquez y Gregorio López y Sandoval y Rivadereyra y Briviesca." $" 43$

"Respuesta al presidente y oidores de los Confines. Presidente e oidores de la nuestra Audiencia Real de los Confines, vi vuestra letra de veinte e uno de mayo del año pasado de quinientos y cuarenta y nueve, en que dáis relación de las causas que os movieron a quesa Audiencia mudase, dende Gracias a Dios a esa Provincia de Guatemala, donde ahora residis y está bien lo que decis que de camino se hizo la tazación de los indios de San Salvador y que también hallaste alli muchos indios e indias que tenían por esclavos y conforme a la Ley que sobre ello dispone, los distes todos por libres, llamadas e oidas las partes, a quién tocaba y que lo mismo hicistes en esa ciudad de Santiago. (Sin fecha)" 44

El 15 de marzo de 1551, el Licenciado Cerrato, escribe a su majestad, denunciando a dos conquistadores "porque van ricos y dicen que se van a morir cristianos" Pilar Sanchiz (1976. pág.107), escribe, "También aprovecha para la defensa su preocupación por la moral social indígena. Al abominar del estado amancebado en que viven como consecuencia de la separación que sufrían los esposos ya que las indias paridas eran llevadas a la ciudad para amamantar a los hijos de las españolas. Estas indias eran:

"las más mozas y recién casadas" "y quedaban los maridos en el pueblo y los hijos y ellas en casa de sus amos. Se amancebaban con otros indios o con los negros y sus maridos tomaban otras mujeres y así quedaban"45

25 de marzo de 1551. Carta del Licenciado Tomás López, dirigida a sus majestades.

\footnotetext{
${ }^{43}$ Fuente: AGI.AG.Leg.393.Fol.87.V ${ }^{\circ}$.

${ }^{44}$ Fuente: AGI.AG.Leg.393. Fol.165.

${ }^{45}$ Fuente: Pilar Sanchíz Ochoa.Los Hidalgos de Guatemala.Publicaciones del Seminario de Antropología Americana. Universidad de Sevilla. Vol. 13. 1976.
} 
"Para este mismo efecto, podía vuestra Alteza, mandar hacer una población muy a propósito, de quince a veinte vecinos, en el Puerto que llaman Acaxutla, que esta hasta treinta leguas de aqui a la mar del sur y veinte de San Salvador y repartirles los pueblos que llaman de los Icalcos y mandar que se adrescase el puerto de Acajutla, porque se daría entrada a mucha contratación por la vía de México y Panamá y con esto hay grande necesidad que vuestra Alteza, no consienta pasar acá soltero ninguno, ni soltera, ni otra gente alguna si no fueren oficiales o labradores con sus mujeres e que a estos, se les compela que usen acá su oficio, el labrador su labranza e agricultura, porque para los repartimientos que acá hay sobra la gente que acá esta y hay necesidad que vuestra Alteza mande que los repartimientos no se den, sino a personas que tuvieren voluntad de perpetuarse acá, porque vienen algunos con propósito de en dos o tres años, coger todo lo que pueden y dexar la tierra despoblada y pobre y asi lo hacen y no sería mala cautela mandarles dar fianza, cuando se les dieren los tales repartimientos, que se obliguen de perpetuar acá o a lo menos de estar acá quince o veinte años." ${ }^{46}$ (El subrayado es nuestro)

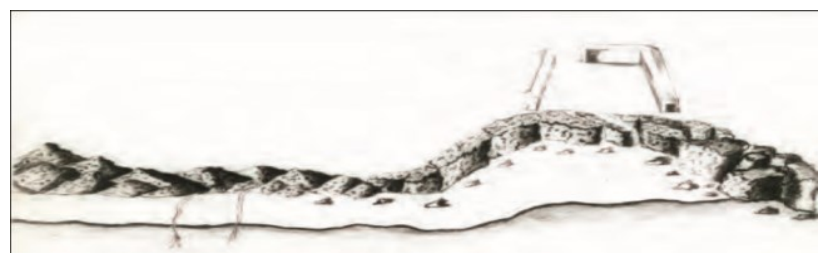

Mapa No.2. Fuente: AGI. M.P. 15. Mapa puerto de Acajutla. (Sonsonate). Pág.157.

\section{Fundación de la Villa de la Trinidad}

El 28 de mayo de 1553 (según algunos autores), se celebra la ceremonia de fundación real de la Villa de la Santísima Trinidad, pueblo de españoles, en la región de los Izalcos. El Obispo Marroquín y el oidor Pedro Ramírez de Quiñones, por instrucciones de la real Audiencia de los Confines y de su Presidente Alonso López de Cerrato, fundan la villa de la Trinidad. En el acto oficial, estaba el oidor Pedro Ramírez de Quiñones. Encomenderos y comerciantes, tenían un solo fin, obtener las mayores ganancias del cacao producido por los indígenas. Los encomenderos, obtenían sus beneficios con el pago del tributo, pero se agrega, las artimañas que emplea para hacerse con el resto del producto, por su posición prepotente, adquiriendo a precios bajos el cacao, lo que crea una competencia declarada con los comerciantes que buscaban los mismos objetivos. El origen del problema lo encontramos en los conquistadores, que ocupan las tierras conquistadas, no con el deseo de abrirse un futuro poniendo en práctica unos oficios, sino con la ambición de convertirse en señores, se les entregan las encomiendas, bajo la amenaza de no ocuparse en oficios, ni mercadear, para no perder su ennoblecimiento. La hidalguía significa inactividad,

${ }^{46}$ Fuente: AGI.AG.Leg.9. (9). Carta de oidor Tomás López dirigida a su Majestad. 
viven a costa del tributo del indígena y dejan sin servicios a los vecinos de las villas y ciudad Los mercaderes se convierten en el apoyo económico de estas hidalguías de Guatemala y San Salvador, convirtiéndose en sus prestamistas y fiadores. El puerto de Acajutla y el comercio del cacao, activa la introducció de esclavos negros en los pueblos de los izalcos. Con los años, estos mercaderes, contraerán matrimonios con hijas de los conquistadores y tratar de cobrar sus deudas, una vez éstos obtienen la merced real.

"Sabe que los vecinos de esta ciudad viven pobremente, con muchas necesidades, porque con las rentas que tienen no se pueden sustentar según los grandes gastos y lo sabe porque es mercader y tiene cuenta con todos ellos y le deben muchos dineros y no los pagan por la necesidad que tienen y así les sobrelleva sus necesidades por condolerse de ellos" $" 47$

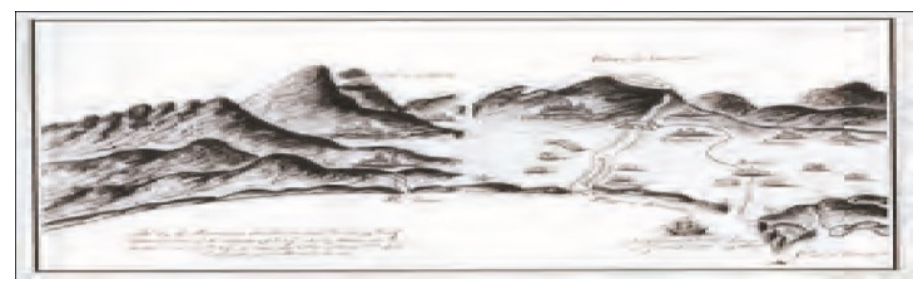

Mapa No 3. Fuente: AGI. Patronato. 259. R. 24636 fols. 125126127.

Puerto y pueblos de la villa de la Trinidad.

Concretando, la causa de la enemistad entre los grupos, conquistadores, mercaderes y vecinos, es la encomienda, el fundamento de ella está en la micro político de los gobernantes, que utilizan su cargo egocéntricamente, favoreciendo a unos y perjudicando a otros, de acuerdo a sus intereses y apetencias.

Gonzalo de Alvarado, dejo el cargo de Alcalde Mayor del Puerto de Acajutla y paso a ser vecino de la villa de la Trinidad, fue sustituido por Francisco del Valle Marroquín, pariente del obispo y casado con Isabel Ortiz de la Puente, prima hermana de éste.

\begin{tabular}{|l|l|l|}
\hline Nombre: & $\begin{array}{l}\text { Puerto de } \\
\text { Acajutla.1553. }\end{array}$ & Procedencia. \\
\hline
\end{tabular}

\footnotetext{
${ }^{47}$ Fuente: AGI.AG.Leg.111. Probanza sobre el número de vecinos de la ciudad de Santiago. 16 de noviembre de 1562 .
} 


\begin{tabular}{|l|l|l|}
\hline $\begin{array}{l}\text { Francisco del } \\
\text { Valle Marroquín. }\end{array}$ & $\begin{array}{l}\text { Alcalde mayor } \\
\text { puerto Acajutla. }\end{array}$ & $\begin{array}{l}\text { Natural del Valle de Guriezo, del Obispado de } \\
\text { Burgos, hijo de Pedro del Valle y de Juan Ruiz } \\
\text { de Marroquín de Pumar, a Guatemala.1 de } \\
\text { marzo. III. 225v } .\end{array}$ \\
\hline
\end{tabular}

Cuadro $\mathrm{N}^{\circ}$ 5. Marroquin Alcalde mayor Acajutla.

La Audiencia dio instrucciones para expulsar a todos los comerciantes españoles de la región cacaotera de los Izalcos y asentarlos permanentemente en la recién creada villa. El nuevo Alcalde Mayor, cumplió las ordenes de la Audiencia, los comerciantes españoles de los pueblos de Tecpan Izalco, Caluco, Izalco, Nahulingo y Tacuzcalco, ayudado por Juan de Guzmán, alcalde ordinario de Santiago y encomendero de Tecpan Izalco con esclavos negros africanos (miembro del Grupo de Salamanca), defendiendo sus intereses, pues bebía de la misma sopa, que compartía con el resto de encomenderos, como lo veremos más adelante en la probanza de méritos y servicios de Francisco del Valle.

\section{Los excesos cometidos por los encomenderos obligan a la Corona, dar una Real Cédula, dirigida a la Audiencia de los Confines, para que se investiguen sobre el modo de tributación y régimen de propiedad prehispánicos}

"Valladolid, 20 de diciembre de 1553. El príncipe Presidente y oidores de la Audiencia Real de los confines. Porque os queremos ser informados de las cosas de yuso declaradas, vos mando que ésta recibáis, como cosa muy importante y que nos deseamos, vos el presidente, con uno de los oidores de esa Audiencia, vos informéis y sepáis de indios viejos antiguos, con juramento que de ellos primero recibáis, que tributos eran los que en tiempo de su infidelidad pagan los pueblos y vecinos de los naturales de esa tierra, al señor y señores, que fueron de ellla, o a otro señor, que tuviere universal señorio, qué tantos eran y cuáles de de la calidad y valor de ellos y que valdrian reducidos a precios de pesos de oro, en cada un año. También os informéis, que tributos y cuantos y que valor tenían lo que daban a los otros principales, sus caciques, que eran sujetos al señor universal, que valdrian en cada un año, además de los que daban al señor de la tierra o al señor universal. Otrosí, informéis si tambien que generos de personas eran los que pagaban los tales tributos, si eran solo labradores, que ellos llamaban macehuales o si tambien pagaban en él, los mercaderes u otras manera de gente. Y si entre ellos habia algun género de hombres que fuese libres de tales tributos. También informéis de los tiempos del año en que pagaban estos tributos y de la orden que se tenía en el repartimiento y cobranza y paga de ellos. Asimismo os informéis tambien, si la paga de estos tributos era por razon de las tierras que labraban y cultivaban, o por razón de las haciendas que poseian, o por respeto de sus personas y asi por cabezas. Item, cuyas eran las tierras $y$ heredades y términos que los indios poseian y si los pagaban el tributo, eran 
solariegos y como tales respondían con los tributos al señor de esa tierra, o si era la paga por razón del señorio universal o particular de los señores. ${ }^{48}$

\section{2. "Carta a su majestad del presidente y oydores de la audiencia informando sobre varios puntos de la provincia.}

"En esa provincia son los caminos muy ásperos y los yndios pocos y no se pueden abrir con ellos, convenia que vuestra majestad mandase dar cuarenta negros para que se abriesen y abiertos se podrian vender y no se perderian los dineros que costasen y los yndios serían muy relevados./Fol. 4./" ${ }^{\prime 52}$

\section{1 de abril de 1556. Carta de la Audiencia a su Majestad, (Fol. 371)}

Tres leguas del puerto de Acajutla se a poblado una villa, donde hay ciento y cincuenta casas, todas de mercaderes y tratantes y se cree se asentara cada día más, solía antes que esta Audiencia se fundase, haber en el Puerto un Alcalde Mayor, agora se manda reside en este pueblo que se llama la Trinidad, para que tenga en justicia la tierra y defienda a los naturales, parece convendra que también pudiese visitar los términos de la ciudad de San Salvador y San Miguel, que están a quince leguas el un pueblo y el otro treinta y cinco, vuestra Majestad mande lo que fuere servido.

-Esta ciudad es la principal y cabecera de todo el Distrito y del regimiento della penden todas las otras ciudades y villas, hay falta de buen regimiento, parece sería cosa útil al bien della, fuese regidor o el que fuese presidente u otro oidor, el que vuestra Majestad fuere servido nombrar, porque habría más orden en todo y podríase ofrecer negocios que importase mucho, se hallase siempre en los cabildos persona de esta Audiencia, en México se hace así, vuestra Magestad mande proveer lo que fuere servido. " 49

\section{La corrupción de los eclesiásticos en la Provincia de San Salvador.}

En lo eclesiástico, la región de los Izalcos había adquirido fama de ser cueva de clérigos comerciantes, de vida no muy ejemplar, lo que hizo reaccionar al 0bispo Marroquín a dirigirse a la Corona en 1556, siendo el cáncer mayor que le ocasionaba fuertes dolores de cabeza. Curas implicados en negocios de cacao y venta de ropa, entre ellos: el cura de Tecpán Izalco, Luis de Fuentes, el de Nahulingo, Francisco de Peralta, antes cura de Santa Ana Cihuatehuacan. Los mismos curas de los pueblos de Izalco, mantenían negocios entre sí, de las preciadas almendras. Traemos a memoria la visita que realizó fray Tomás de la Torre por orden del Obispo en 1552, el cual

\footnotetext{
${ }^{48}$ Fuente: AGDCA. Signatura A-1.23. leg. 4575. Fol.176. 52 Fuente:

AGI.AG.Leg.9. 20 de julio de 1545.

${ }^{49}$ Fuente: AGI.AG.Leg.43.
} 
descubrió los escandalosos excesos del Cura Sebastián Cuadrado, vicario de Ahuachapán. Estando en Ataco hizo comparecer ante él a los caciques, como al alguacil de dicho pueblo y dieron inicio a unas serias denuncias sobre los excesos y abusos de autoridad.

El cura de Ahuachapán tres días antes de las fiestas los convocaba a que hicieran donativos, tasando a cada indio principal a que diera 1 toston: el macehual 2 reales; las indias 200 granos de cacao; los niños 20 almendras. Un día en la festividad de la Ascensión exigió 2 jiquipiles de cacao, al no ser de su agrado los tiró por el suelo. Los caciques entregaron 4 jiquipiles más y aún no satisfecho, los azotó en nombre del obispo, agregándose, que les hacía ver que los naturales de Ahuachapan, les habían hecho un donativo de 60 tostones y 2 cargas de cacao. Por casarlos les llevaba 2 reales a cada uno de los contrayentes. Por deceso, exige una manta o huipil. Al ser nombrado estuvo residiendo en Ataco y cada semana los naturales le daban: 15 gallinas, siete de la tierra -pavos- y ocho de Castilla, como el pan necesario, los días que visitaba el pueblo. Exigía que las gallinas fueran sanas y gordas, si no lo eran les pegaba con ellas al portador. Al tener muchas las enviaba a Izalco para su venta, obteniendo por las de la tierra 5 zontles de cacao por cada una. Los jóvenes del pueblo le servían en mantenerle los cerdos, conejos, cabras y caballos, como lo mandaba la tradición de los señores conquistadores. Les exige velas de cera, que manda a vender a Izalco para comprar cacao. Fue pública voz y fama que secuestro a la mujer del cacique y la mantuvo en su casa, mientras estuvo éste de viaje, hasta que pudo escapar de Ataco.

Las denuncias de los habitantes de Ataco, le siguen las de los naturales de Apaneca, cobros en cacao, azotes por no ser suficiente, hacerle sementeras de maíz, vender la cosecha, cobrar por casamiento a los contrayentes, por funeral. A los caciques les hacer ir a Ahuachapán a "besar la estola", exigiendo 2 reales por cabeza. Lo mismo denuncian los de Salcaoatitlán, los de Naguizalco contrata el clérigo Juan Ruiz de Gamboa, por tener una india como cocinera, era su amante, no pedía dinero, pero recibía donativos cuantiosos por casamiento, 4 reales, por cacique 1 o 2 reales y los indios le mantenían caballos, le daban gallinas de Castilla y de la tierra.

Sobre el cura de Izalco (pueblo de Juan Guzmán), Francisco Gómez, como los anteriores, Juan Juárez y Monterroso, acusaron al primero de mantener relaciones sexuales con la hija del cacique, de comer juntos con el rico cacique, de traficar con vino que enviaba a comprar con el alguacil a Acajutla y lo adulteraba, cobrando por cada botija de vino, una carga de cacao, por botella 22 o 24 pesos, su principal cliente el cacique del pueblo que vive siempre embriagado y a pesar de tener manceba, no se le ha amonestado, los mismos abusos de cobro de dineros, de velas de cera, de vigilar sus pertenencias y cacaotales. Diariamente le dan 1 gallina de Castilla y 1 de la tierra. De Monterazo no hubo quejas salió limpio de la visita. El clérigo Juan Juárez, era pícaro de ciudado, tenía a otra hija del cacique, casada, traficaba y comerciaba con el cacao, venta de vino, suyo negocio abarcaba hasta el pueblo de Tacuscalco. 


\begin{tabular}{|c|c|c|}
\hline $\begin{array}{l}\text { Nombre: Eclesiásticos } \\
\text { implicados }\end{array}$ & Pueblo. & Incidencia. \\
\hline Cura Luis de Fuentes. & Tecpán Izalco. & Negocio de cacao y venta de ropa. \\
\hline $\begin{array}{l}\text { Cura Francisco de } \\
\text { Peralta, antes cura de } \\
\text { Santa Ana } \\
\text { Cihuatehuacan. }\end{array}$ & Nahulingo, & Negocio de cacao y venta de ropa. \\
\hline $\begin{array}{l}\text { Cura Sebastián Cuadrado, } \\
\text { vicario de Ahuachapán. }\end{array}$ & $\begin{array}{l}\text { Ahuachapan. } \\
\text { Ataco. }\end{array}$ & Excesos e abusos de autoridad. \\
\hline Cura de Ahuachapán. & Ahuachapán. & $\begin{array}{l}\text { Tres días antes de las fiestas los convocaba a } \\
\text { que hicieran donativos. Pegaba a los } \\
\text { indígenas. Secuestro a la mujer del Cacique } \\
\text { y la tuvo en su casa. }\end{array}$ \\
\hline & Apaneca. & $\begin{array}{l}\text { Cobro de cacao, azotes, hacerle sementeras } \\
\text { de maíz, vender la cosecha, cobrar por } \\
\text { casamiento, cobro por funeral. A los } \\
\text { caciques les hacer ir a Ahuachapán a "besar } \\
\text { la estola" exigiendo } 2 \text { reales por cabeza. Lo } \\
\text { mismo denuncian. }\end{array}$ \\
\hline & De Salcaoatitlán & Lo mismo denuncian. \\
\hline $\begin{array}{l}\text { Clérigo Juan Ruiz de } \\
\text { Gamboa. }\end{array}$ & Naguizalco. & $\begin{array}{l}\text { Por tener una india como cocinera, era su } \\
\text { amante, no pedía dinero, pero recibía } \\
\text { donativos cuantiosos por casamiento } 4 \\
\text { reales, por cacique } 1 \text { o } 2 \text { reales y los indios } \\
\text { le mantenían caballos, le daban galllinas de } \\
\text { Castillla y de la tierra. }\end{array}$ \\
\hline
\end{tabular}




\begin{tabular}{|l|l|l|}
\hline Cura Francisco Gómez & $\begin{array}{l}\text { Venta de vino, cuyo negocio abarcaba hasta } \\
\text { el } \text { pueblo de Tacuscalco. mantener } \\
\text { relaciones sexuales con la hija del cacique, } \\
\text { (pueblo de } \\
\text { Juan Guzmán), } \\
\text { traficar con vino por cada botija de vino, } \\
\text { una carga de cacao, por botellla } 22 \text { o 24 } \\
\text { pesos }\end{array}$ \\
\hline Clérigo Juan Juárez. & Izalco. & $\begin{array}{l}\text { El clérigo Juan Juárez era pícaro de } \\
\text { ciudado, tenía a otra hija del cacique, } \\
\text { casada, traficaba y comerciaba con el cacao, } \\
\text { venta de vino, suyo negocio abarcaba hasta } \\
\text { el pueblo de Tacuscalco. }\end{array}$ \\
\hline Cura Monterroso. & $\begin{array}{l}\text { De Monterroxo no hubo quejas salió limpio } \\
\text { de la visita. }\end{array}$ \\
\hline
\end{tabular}

Tomás López continuó la investigación y encontró que en San Salvador Juan Ruiz de Gamboa y Juan Juárez, el primero estaba en Cojutepeque, amancebado y con caballeriza donde tenía 6 o 8 caballos alimentados por los indios del barrio del Calvario. De regreso de sus visitas regresaba con 300 gallinas de Castilla que enviaba a comerciar en el pueblo o la remitía a Izalco para pero nunca asistía y cuando lo hizo pidió alimentos por valor de 16 reales.

\begin{tabular}{|c|c|c|}
\hline $\begin{array}{l}\text { Nombre: Eclesiásticos } \\
\text { implicados San Salvador }\end{array}$ & Pueblo. & Incidencia. \\
\hline $\begin{array}{l}\text { Cura Juan Ruíz de } \\
\text { Gamboa }\end{array}$ & Cojutepeque. & $\begin{array}{l}\text { 1.Amancebado, } \\
\text { 2-Tiene caballeriza } 6-8 \text { caballos } \\
\text { alimentados por los indios, del barrio del } \\
\text { Calvario. } \\
\text { 3-Lleva } 300 \text { gallinas de Castilla, vende en } \\
\text { el Pueblo de Izalco para comprar cacao. } \\
\text { 4- Porta espada y daga al cinto }\end{array}$ \\
\hline Cura Juan Juárez. & Huizucar. & $\begin{array}{l}\text { 1- Cura Huizuca, nunca asistia. } \\
\text { 2- Pide alimentos por } 16 \text { reales. }\end{array}$ \\
\hline
\end{tabular}

Cuadro $\mathrm{N}^{\circ}$.7. Incidencia.

Las pruebas que comprobaban los excesos que se cometían en los indios de la Provincia de San Salvador, siguieron acumulándose en la visita de Tomás López de la Torre. En el 
convento de los dominicos de San Salvador encontró a varios implicados en el sucio negocio. El Obispo Marroquín salía mal parado por la falta de mano dura contra el clero indeseable, a tal grado que tuvo que ser reivindicado por el nuevo Presidente de la Audiencia, el Presidente Juan Martínez de Landecho en 1560.

En Honduras y Chiapa, ocurría lo mismo, excesos que la Audiencia no puede remediar por estar lejos, es evidente la necesidad de Justicia Mayor, ya que los oidores no pueden

\section{Fuente: Carta dirigida a su majestad. Guatemala a 30 de julio de 1557:}

El oidor Antonio Mejía, oidor de México, nombrado en Guatemala, escribe a su Majestad un largo informe el 30 de julio de 1557 sobre su llegada a la Audiencia, donde encontró al decano oidor Licenciado Pedro Ramírez de Quiñones y García Jofre de Loaisa y después lo enviaron a visitar la ciudad y provincia de San Salvador, en la cual encontró, casi todos los pueblos cargados de tributos, que había pueblos de 20 indígenas, cargados con tributos que ascendían a 600 pesos de minas de renta por año. El informe en su mayoría escrito contra Juan de Guzmán. Mejía procedió a su moderación y nueva tasación, sugiriendo que se debían de quitar la mitad de los tributos en toda la Provincia, aun así, le parece que quedan muy cargados los indios, pues el que menos paga por año, es diez o doce tostones de cuatro reales de plata y entiende que es poco, comparado con lo que le llevan los frayles dominicos, además del señorío que pretenden tener en toda la tierra, para que los oidores no hagan nada en contra de sus acciones a pesar de lo mandado por la corona. Ellos usan libremente la jurisdicción real: hacen Audiencia, detienen, azotan y castigan con fiscales que tienen con vara de justicia en cada pueblo.

En algunos pueblos que el oidor Mejía visitó, los dominicos repartían tributos para la orden: dineros, mantas y otras menudencias en gran cantidad, agregado que les tenían que hacer sus sementeras de maíz, mantenerlas, coger el grano y llevárselo al pueblo. El oidor personalmente comprobó la gran cantidad recogida para beneficio propio, sin dar cuenta y razón de todo, bajo el pretexto de comprar algunos ornamentos y cosas para la iglesia, aunque son pocos y excesivos los tributos que no hay proporción, entre lo uno y lo otro. Los dominicos interfieren la visita al oidor Mejía, so pretexto de que no les pide parecer, ni licencia, para ello, llegan incluso a requerirle por escrito como lo demuestra por los autos que envió a la Corona. A pesar de querer el oidor entenderse con los dominicos no pudo llegar a ningún acuerdo. Estando el oidor Mejía en la visita de los pueblos, enviaron frailes a la Audiencia, donde interpusieron quejas contra el funcionario real, por impedir la doctrina de Jesucristo, que no llevasen a los indios tributos, ni otras cosas, ni usaran de la jurisdicción real, le fue puesta acusación pública en la Audiencia ante los oidores. Con ellos llegaron muchos españoles, quejándose que los había acortado mucho los tributos, tasaciones, ordenando que los indios llevasen más de lo que él, les había señalado, todo lo que hizo en la visita no tuvo ningún efecto. A lo anterior, se agrega, que el obispo era partidario de los frailes y éstos pidieron a instancia de los otros conventos, junta pública en la iglesia mayor de la ciudad de Santiago, donde se reunió la Audiencia, el obispo, 
religiosos, clérigos y seglares, donde los dominicos expusieron sus quejas. Lo actuado en la visita y los autos formados por el oidor Mejía, dejaron confusos a los reunidos, justifica el oidor, que en lo tocante, la mayor acusación que se le imputa por parte de los frailes, eran los tributos que llevaban y excesos que hacían y que ningún juez se los impidiera, lo que lleva a decir el oidor Mejía, "que lo que era ocasión de santidad que es tener hábito de religioso, toman por libertad para hacer y decir". Mejía escribe que si cometió un error ya estaba solucionado, pues no se cumplió lo que él proveyó y ellos se han negado con palabras y obras. Aviso que todo se verá en los autos que envía a la Corona y que el Rey mande ver y provea lo que más sea servido.

No había ninguna duda sobre las justificaciones del oidor Mejía, los poderosos conquistadores-vecinos de la villa de San Salvador, como los encomenderos de los pueblos de Izalco, que vivían en la ciudad de Santiago, no querían perder sus sustanciosas rentas, pues los últimos, siendo algunos regidores de la ciudad de Santiago, incluso portaba la vara de autoridad cabildante en el pueblo de su encomienda. Los frailes dominicos eran los más mayoritarios en todo el Distrito, la orden Francisca y de la Merced, no eran lo suficientemente fuertes para hacer contrapeso a los primeros, por lo que tenían controlados todos los pueblos de las provincias y así lo denuncia el oidor Mejía, en la ciudad capturan y castigan indios e indias, ponen denuncias a alcaldes indios sin cargo alguno que sea justificado, si se dejan en libertad, los vuelven a prender y los llevan al convento, donde son puestos en cepo y los azotan cruelmente. Por no tener jurisdicción los miembros de la Audiencia en ellos, se ríen de los oidores, hacen edificios y obras excesivas con indios, sin pagarles materiales ni jornales, algunos indios mueren en las obras y el oidor lo había presenciado.

Respecto a los tributos, cada indio paga sesenta pesos de minas por año a su encomendero, que son ochocientos reales de Castilla, cuando en México, un indio casado no paga más de ocho a diez reales arriba por año. Si se les hace información los excomulgan. Esta es la situación del indígena y el panorama que presenta la provincia de San Salvador. Pero al oidor Mejía se le complicarían las cosas, Diego de Guzmán, es elegido Alcalde Ordinario de la ciudad de Santiago de Guatemala y mueve piezas para atacar al ingenuo oidor y propuso una pesquisa secreta contra dicho funcionario, el "grupo de Salamanca" dio paso a su revancha mezquina camuflada en la legislación.

La jurisdicción de Ízalco, era la más azotada por las injusticias de los encomenderos los tratantes de cacao, a pesar de la presencia de Alcalde Mayor, los poderosos señores continuaban con sus desmanes, es así que el oidor Juan Mejía, escribe a la Corona el 30 de julio de 1557, otra carta relación de su visita. Quejándose de que los pueblos de indios estaban excesivamente cargados de tributos y presencia de esclavos negros.

"CATÓLICA REAL MAJESTAD. Yo vine de vuestra Audiencia de México a servir a vuestra Majestad en esta Audiencia de los Confines, abra un año, poco más o menos, do halle por oidores a los licenciados Pedro Ramírez de Quiñónez y a García Jofre de 
Loaiza y poco después de venido, me mandaron fuese a visitar la ciudad y provincia de San Salvador, en la cual halle quasi todos los pueblos muy cargados de tributos, tanto que hubo pueblos de veinte y tantos indios que estaban tasados en cuasi seiscientos pesos de minas de renta por año. Táselos todos y moderemos y creo que de toda la provincia quitaría la mitad de los tributos y con todo aún me parece quedan los indios muy cargados, pues el que menos paga por año, creo, pagara diez o doce tostones de a cuatro reales de plata y a los que entiendo es muy poco lo que los indios dan a sus encomenderos en comparación de lo que les llevan los frailes señaladamente los dominicos, porque de más del señorio que pretenden tener en toda esta tierra para que los oidores no hagan más ni menos de lo que ellos mandaren con los indios usan librante de vuestra jurisdicción real haciendo audiencias, prendiendo, açotando y castigando públicamente con fiscales que tienen con varas de justicia en cada pueblo.

Fui informado que en algunos pueblos de los que yo visitaba y estaban a su cargo e visita, repartían tributos por los indios para si, en dineros, mantas y otras menudencias en gran cantidad y demás de esto, les hacian hacer sementeras de maiz de las cuales se cogen e yo ví cogidas grand cantidad para los frailes, los cuales lo encierran en su casa y venden libremente para si, sin que haya más cuenta ni razón, aunque en algunas partes dan color que de aquellos tributos y milpas, compran algunos ornamentos y cosas para la iglesia, que aunque fuese asi, lo que compran es en tan poca cantidad y lo que llevan tan excesivo, que no hay proporción. Yo procuré poner remedio en todo y señaladamente en esto de los frailes de Santo Domingo, de lo cual resulto, que por esto o porque no quise pedirles parecer y licencia para todo lo cual había de hacer y proveer e la visita lo cual pretendieron tan de veras, que aún me lo requirieron por escrito, como vuestra majestad podrá ver por los autos que con esta envío, do se contiene algunos cosas que los frailes pasaron conmigo y yo con ellos y lo que yo provei sobre ello, sin atravesarme con ellos, aunque me dieron grandes ocasiones, finalmente estando yo en la visita, vinieron a esta Real Audiencia, dos frailes dellos, ase quejar de mí, diciendo que les impedia la doctrina de Jesucristo, porque les impedia que no llevasen a los indios tributos, ni otras cosas, ni usasen de vuestra real jurisdicción y me pusieron públicamente una acusación en esta Real Audiencia, ante los oidores, mis compañeros y con ellos vinieron muchos españoles quejandose que les había acortado mucho los tributos y tasaciones y se proveyo que se suspendia y daba por ninguno cualquier cossa que yo hubuiese hecho, tocante a los frailes y se acrecentaron cuasi todas las tasaciones, mandando que los indios tuviesen más de lo que yo les había señalado y así cuasi ninguna cosa de cuanto hice e la visita hubo efecto. Vuestra Majestad podrá proveer en ello que quemás sea servido. Venido yo aquí, de la visita, vi que también el obispo era con los frailes y dio mandamiento para que no se obedeciese lo que yo mandaba en la visita, sino lo que los frailes hiciesen, ordenasen y mandasen y a instancia de las otras religiones, se hizo junta pública en la iglesia mayor de esta ciudad, presente el Audiencia y Obispo y todas las religiones y muchos clérigos y seglares y alli, los dominicos pusieron sus quejas, estando presente todos los autos que yo había hecho en la visita y habiendo ellos propuesto sus quejas contra mí, con solo los autos les respondi y a mi parecer quedaron confusos y asi ellos tienen razón, o yo hice justicia, vuestra Majestad lo podra mandar ver en los mismos 
autos, en los cuales hay una cosa de que ellos más se queja, queran a mi ver es la más justificada y que yo hice y es que al principio que me informaron de los tributos que llevavan y exceso que hacian, luego di parte si era verdad, lo remediásemos, sin que se escribiese nada y si no era verdad, castigasesmos a los indios, que tales testimonios les levantaban, el cual quasi me concedio lo que los indios decian y quedando él y yo de juntarnos para dende a dos o tres días, comparece por el auto que esta en el mismo proceso, firmado de mismo frailes, debiolos comunicar con sus compañeros y saliose a fuera y echaron lo por lo valiente, haciéndome fieros si tratara de ellos y yo para más justificación, envié a dar parte al prior y frailes a quien tocaba para que no juntasemos y lo remediasemos en secreto, sin que nadie nos entendiese, los cuales e pago de tan buen comedimiento mio, me excomulgaron públicamente, como parece por la excomunión firmada del Prior de la misma casa, que esta en el proceso, mi fin fue averiguar la verdad, no para castigar lo pasado, sino para remediar lo de adelante, que no basta ser lo que yo proveyese se diese noticia a vuestra Majestad y pusiese el remedio que fuese servido en resolución ellos no quieron dejar de llevar los tributos y hacer excesos, ni que juez alguno se informe dello, ni aun les hable y lo que les había de ser ocasión de santidad, que es tener hábito de religioso, toman por libertad para hacer y decir, si yo erre ya esta remediado ,pues no se guarda lo que proveí y ellos se han negado con palabras aun obras. Si yo areste en algo, vuestra magestad, lo mande ver y provea se guarde lo que sea servido. Yo holgara enviar todos los procesos de mi visita, para que por ellos constara la orden que tuve en todo, pareceme que todo este Distrito tiene grandisima necesidad de vista porque los pueblos son muchos y de pocos indios y ellos de si miserables y los tributos muy excesivos y los clerigos y frailes se aprovechan de los indios excesivamente, verdad es, que los clérigos, no exeden tanto como los frailes y de los frailes solo los dominicos, que son muchos y tienen ocupadas cuasi todas la tierra, porque los franciscanos y de la Merced, son pocos y a mi juicio, están bien reformados y no solo pasa lo que dicho de los dominicos en la provincia que yo visite, pero en los otros pueblos y provincias, que tienen a su cargo, soy informado que hace quasi lo mismo, y en esta misma ciudad, prenden y castigan a los indios e indias y no ha mucho dias, que teniendo presos en la cárcel de esta Real Audiencia, dos indios alcaldes a instancia de los frailes dominicos y después de muchos días, no los hallando culpados, les dimos esta ciudad por cárcel y visto por los frailes que no les castigábamos, habiéndoles hecho ellos prender, los llevaron al monasterio de Santo Domingo y los tuvieron presos encarcelados muchos días en un cepo y los azotaron bravamente y salidos de allí, se vinieron a quejar a nosotros, yo vi las llagas y livores de los azotes y como los frailes ven que no tenemos jurisdicción sobre ellos, se rien de nosotros y aun dicen que si les impedimos que no lo hagan, no doctrinaran los indios. Y ahora pocos días, a un fraile dominico, hizo encarcelar una india en esta ciudad, y quejándose della a mí y habiéndome informado no haber proceso, ni delito, ni otra causa justa, la puse en libertad y sobre ello me tuvo excomulgado el obispo, hasta que sin ser yo parte para lo estorbar, la tornaron a encarcelar y demás desto hacen edificios y obras excesivas para sus monasterios con indios, sin pagarles materiales, ni jornal y llevándoles por fuerza a ellos y lo que pero es algunas veces e tiempo que los indios, tienen necesidad de ocuparse en sus sementeras y 
aun no les dan comida ni bebida, por el tiempo que se ocupan en las tales obras, como también muchos indios, en las tales obras, por los excesivos trabajos que les ponen y estado yo aqui presente, han muerto y lisiadose ciertos indios, con unas vigas grandisimas que traían para una capilla, que los frailes de Santo Domingo hace en el patio de su iglesia, y como yo venía de la Real Audiencia de México, do no se acostumbra construir a religiosos, hacer obras excesivas con indios, sin licencia y pagándolos y no les impidiendo sus sementeras, quisiera que aquí se hiciera otro y de aca no hay remedio que baste, con la orden de Santo Domingo, si de allá vuestra majestad no lo remedia y provee. Y es cierto que ellos, que publican el remedio y favor para los indios y sería justo, que lo hiciersen, son los que más, les molestan y agravian y no se maravillaría que en pago demis trabajos y voluntad que he tenido, en poner remedio e lo que he dicho, fuese quejas de mí, ante vuestra Majestad de los frailes, porque les voy a la mano en lo malo y de los encomenderos, porque les he acortado las tasaciones excesivas que tenían y como de los que he hecho hasta aquí, entienden que adelante, hacer lo mismo en todo lo semejante, procuran caer mi nombre del libro de la vida, confia en vuestra Majestad no creera nada sin oirme. En lo de las tasaciones creo, que generalmente, todo este Distrito está excesivamente tasado, a lo menos en respecto de la Nueva España, pues en ella no me acuerdo haber sabido de tasación por la cual ningún indio casado, pague de ocho o diez reales arriba por año y en este Distrito, yo conozco algunos indios tributarios, de los cuales pagan cada uno, más de sesenta pesos de minas por año de tributos a su encomendero, que son ochocientos reales de Castilla y de esto yo doy fe como testigo de vista, aunque a vuestra Majestad le paresca increible. Porque viniendo yo vistando llegue a los içalcos que son dos pueblos encomendados en Francisco Girón y Juan de Guzmán, que sin ser conquistadores, ni hijos de ellos, los poseen, antes el Juan de Guzmán, dicen que es hijo de Diego de Guzmán, vecino que fue de Salamanca, bien señalado en las comunidades y ningún oidor, ni justicia vuestra, ha bastado a le visitar su persona $y$ pueblo de muchos años a esta parte, antes habiendo ido ello, el Licenciado Rogel y después el Licenciado Tomás López y después de ellos, el licenciado Zorita y después de todos ellos, yo, ahora ha tenido siempre formas como ningun dello, ni yo, moderasemos las tasaciones, ni conociesemos de sus excesos y de tres cuñados suyos mancebos, que el tienen en el dicho pueblo, los cuales y otros sus parientes y allegados, negros y criados, que digo tienen, han hecho grandes excesos, según qué estado yo allí, fui informado y queriendo hacer proceso en ello y tasar el pueblo, fui mandado por esta Real Audiencia, venirme con formas que el dicho Juan de Guzman e Francisco de Giron, tuvieron para ello y ansi se quedó todo mi deciso, pareciome, que cada uno de los dichos dos pueblos ternia ciento y cincuenta o doscientos casados tributarios y están tasados cada un pueblo, en más de cuatro mil pesos de minas de renta, cada un año, y aunque las tasaciones son tan excesivas, me parecio este el menor agravio que los indios reciben en comparación de los malos tratamientos y bexaciones que el Juan de Guzmán y los demás les hacen. Es tan poderoso y favorito allí donde reside, con su casa, mujer y parientes y criados, que aunque esta Real Audiencia envía a remediar algunas cosas, cuasi ninguna se efectúa, dieronseme alli memoriales de grandes excesos suyos, que tengo en mi poder, que por ser muchos, no envío el traslado de ellos a vuestra Majestad, sé que conviene al descargo 
de vuestra Majestad, conciencia, proveer señaladamente algunas cosas en aquellos dos pueblos que son la principal, que las tasaciones se moderen conforme a la cantidad de indios. La otra, que el Juan de Guzmán, no resida como residen con su mujer, casa, cuñados y allegados en el dicho pueblo, pues es contra ordenanzas. La otra que se haga justicia de todos los excesos que él y su mujer, cuñados y allegados, parientes y sus negros y criados, hayan hecho en el dicho pueblo, después que le posee, la otra y esta es notable, que el recoger de los tributos, diz que no tienen cuenta, ni razón, ni quiere que se halle justicia, ni otra persona delante, sino que él, por su persona, pide a cada un indio, lo que le parece o quiere a su voluntad, y si esto es así, no solo recogerá lo contenido en la tasación, aunque como dicho es, excesivo, antes podrá recoger, quince y veinte mil pesos y cuanto quisiere, sin que se le pueda averiguar, ni probar por alguna vía y tiene los indios tan sujetos y amedrentados, que estado el presente por ninguna vía, se podría averiguar la verdad, asimismo, tiene en el dicho su pueblo y comarca ciertas milpas de cacao y otras granjerías e que además de los servicios personales que tiene los indios, son agraviados con estar los unos en haciendas y otros mesclados en las acequias y regadios y en el coger de los frutos, que están en su mano del y sus negros y criados, coger de las milpas comarcanas el cacao, que quisiese sin que los indios lo vean $y$ aun que lo viesen no osaran pedirlo.

Creo que le rentan estas milpas más de cinco mil pesos de minas cada año, no se si tienen titulos de ellos, no tengo entendido que esto tienen remedio si vuestra Majestad no provee particular visitador para ello y que la apelación de lo que el hiciere, vaya a ese Real Consejo. Tiene asimismo, dos encomiendas diferentes, una la del pueblo de indios que he dicho y otra, que hizo en el licenciado Maldonado, no pudiendo de dar, ni Dios, al que tiene otros indios y debiendo dejarlos para tomar los otros, conforme a vuestras provisiones y por ser aquí estos dos pueblos tan principales y estar en el puerto de Acajutla, puerto de mar y muy usado, se habia de poner en vuestra Real Corona a lo menos el de Guzmán, por ser hijo de quien es, y aunque entiendo que en esta tierra, hay muchas cosas que tiene necesidad de remedio, tengo esta por muy impotante y necesaria y que para esto, de Juan de Guzmán y Frailes dominicos, convenía venir remedio de ese Real Consejo, porque no vaya el mal crecimiento cada día. Convenía tambien que de ordinario andavuiesen dos o tres oidores visitando la tierra, a los cuales vuestras Majestad señalase salario competente, porque con quinientos maravediz que tenemos de salario, es imposible sustentarnos, ni la mitad del año, pues casi todas las cosas valen seis tanto y ocho tantos, que en Castilla y los seis mil maravedis que vuestra Majestad da, de ayuda de costa, al oidor que visitare, del tiempo que se ocupase, es mиy poco, porque aunque no sea más de llevar una cama e que duerma y ropa que se vista, gasta el doble de lo que gasta estando en su casa y es cierto que aunque vuestra Majestad señale un ciento a cada oidor que visitase, creo le sería necesaria, según los gastos que yo vi, por todas las tierras que visite. En México cuasi no hay desorden alguno de los que he dicho y a los frailes y clérigos, les estan señalados salarios, sin que tengan entrada, ni salida con los indios y asi debería vuestra majestad mandar, se proveyese aquí, por que como los indios no ven otro Rey, ni señor, sino al fraile o clérigo que esta en su 
pueblo, ni tienen habilidad ni posibilidad, para se venir a quejar y si alguno por desdicha acierta a quejarse, cuasi jamás se pone remedio y al querellarse por haberse quejado, le castigan y molestan el frayuelo el clérigo, no me maravillo que viendo esto los indios los tengan por señores.

En México, como hay corregidores, cuasi en cada lugar de indios, no hay tanta ocasión para consertirse semejantes excesos, que esta tierra es mas extendida y menos poblada y en toda ella, no hay pueblos de indios, donde resida corregidor, ni justicia y asi estas cosas de indios padecen aquí extrema necesidad y trabajo y demás de esto, las tasaciones tambien excesivas, en las cuales convenia que vuestra Majestad de alli, proveyese no pagase de tributo, cada casado, en cada un año, de diez o veinte o treinta reales arriba o su valor o la cantidad que vuestra Majestad sea servido, pues los indios de aquí y de la Nueva España son todos unos y antes me parece que los de la Nueva España son más sanos y regios y si los de aquí son menos poblados, que los de allá, debe ser la causa los excesivos tributos y servicios. Se que volver por los indios e ir a la mano a los frailes, estoy en desgracia de españoles y frailes y tengo de ser perseguido de ellos, yo me terne por muy bien pagado de los trabajos pasados y los que me puedan venir, con que vuestra Majestad ponga en todo el remedio que convenga.

Yo sali pobre de México, porque con pleitos y enfermedades, sali adeudado y aqui que tengo menos salario y mayor costa, por ser las costas muy más excesivas que en México, cuasi el doble, y pues la ocasión de sacarme de allí, debió ser las pasiones del doctor Herrera y el está ya en España en su casa y yo acá tan pobre y el pleito memorial ceso, porque demás que yo fui absuelto, por semejante difamación, la misma parte se desdijo ante el arzobispo y confeso, habiendolo rebajado y después caso y está casado, con un caballero de esta provincia y por la residencia que en México se me tomó y en ese Real Consejo se vio y determino, fui dado por buen juez y no hubo queja de persona alguna contra, ni cargo ruin, suplico a vuetra Majestad se me haga alguna merced, pues soy el primer oidor pobre de cuantos aca han pasado y si he estado de algún mal que esto en México, creo ha sido la causa haber yo procurado servir a Dios y a vuestra Majestad, haciendo justicia con libertad y si aqui lo estuviese, creco sera por lo mismo y por lo mucho que deseo volver por estos miserables indios en las cosas que provei e la vista que hice, es una que los ornamentos para las iglesias de los indios, se comprasen a costa de los mismos indios, de las sementeras que yo les mandaba hacer en cada pueblo, para sus ciudades e iglesias, como parece por los autos que envió y después acá, pensando más sobre ello, me ha parecido que yo agraviava a los indios, porque pues tributan todo lo que pueden, conforme a su posibilidad a sus encomendero, si la causa porque los encomenderos llevan los tributos, es por el cargo que tienen de doctrinales y hacerles administrar los sacramentos, tanto que si en esto ubiese negligencia, manda vuestra Majestad, sea causa bastante, pales privar de los indios, pareceme que el encomendero que lleva todo los que los indios le pueda dar, para efecto de hacerles cristianos, es obligado a les dar sacerdote pagado y ornamentos, con que se les diga misa y tenga sus iglesias adornadas y es harto obligar a los indios, a los edificios y reparos de sus iglesias, y a que den todo lo necesario para la comida y gastos de sacerdotes, vuestra majestad lo 
vea y provea, tambien se de cierto, que hay muchos indios, que no son cristianos, ni estan bautizados y otros qual, que lo están, no saben cosa es Dios, porque no hay quien les industrie a causa que los frayles y clérigos, buscan los pueblos ricos y gruesos y hacen poco caso de los demás, mande vuestras Majestad, que esto se provea, también hay una provincia muy grande y bien poblada que se dice Tecutlatan, en la cual no está español, ni justicia vuestra, y se gobierna solamente por frailes dominicos, y se tiene por cierto, que los frayles llevan de alli, grandísimas de tributos y rentas y que tienen allí, servicios personales, y aun esclavos indios y como diz que tienen provisión de Vuestra Majestad, para que ninguna justicia vuestra puede visitar aquella provincias, ni estar en ella, ni español, ni otras persona alguna, sin licencia de los frailes y ellos, no la dan a nadie, podrá verdad lo que se dice y mucho más aventurarse, ya poco e que vuestra majestad comandase visitar, nuestro señor la Católica y Real persona de vuestra majestad guarde, con acrecentamiento de mayores señoríos, para su servicio de Guatemala a 30 de julio de 1557. El Doctor Mejía." 50

Juan de Guzmán ¿Qué poder tan grande tenían para actuar así? Por esta fecha, había bajado el índice demográfico de la población indígena, tenía cada pueblo entre 150 y 200 tributarios casados y pagan más de 4.000 mil pesos de minas de renta cada año. Lo más grave según el oidor, eran los malos tratamientos y vejaciones que les hacía el Juan de Guzman y sus compañeros.

\begin{tabular}{|l|l|l|}
\hline Pueblo Izalco & Número de tributarios & Tributo \\
\hline Juan de Guzmán & 200 casados & 4.000 pesos de minas \\
\hline Francisco Girón & 150 casados & \\
\hline
\end{tabular}

Cuadro $\mathrm{N}^{\circ} 8$. Número de tributarios.

El poder que había alcanzado Juan de Guzmán, se agrega, que por su condición, es favorecido donde reside con su casa, mujer parientes, esclavos negros, criados y por los españoles a pesar de ser contra las leyes de la corona., por lo que pide se pongan en la real corona, por lo menos al de Guzmán por ser hijo de quien era, en esta última frase puede reducirse la personalidad y reputación de Juan de Guzmán, en Guatemala y Villa de la Trinidad. Las necesidades de orden y remedio en toda la tierra que comprendía la jurisdicción de los pueblos de Izalco, como en la provincia de San Salvador, especialmente, lo de Juan Guzmán y frailes, eran urgentes y así lo hacía ver el oidor Mejía, recomendando que convenía el remedio del Real Consejo, para que los excesos no aumenten cada día.

Mejía, sugiere que se de orden que ordinariamente anduviesen dos o tres oidores visitando la tierra a los que se les señale salario competente. El funcionario "insiste" en que los 500 maravedís que tienen de salario, no son suficientes para sustentarse, ni la mitad del año, por lo caro que es vivir en esas partes, más que en Castilla. Por este tiempo, los funcionarios, ya no son comedidos en solicitar el aumento de sueldo, sino

${ }^{50}$ Fuente: AG Leg.9.Fol.384. 
que puntualizan la urgente necesidad del aumento de salario. Los 6.000 mil maravedís de ayuda de costa que se dan para la visita, es muy poco, pues tiene que llevar todo y gastar el doble que estando en su casa. Pide se señale 100.000 maravedís a cada oidor que visitase por ser necesario según los gastos.

Mejía no se detiene en ejemplarizar que en México casi no hay este desorden de los arriba mencionados. Los frailes y clérigos, les están señalados salarios, ni tengan entrada, ni salida con los indios, pues los indios, no ven otro Rey, ni Señor, sino al fraile o clérigo que esta en su pueblo, ni pueden quejarse por haber interpuesto denuncia, los castigan y molestan el fraile o clérigo. Mejía expresa:

“...que no se maravilla queriendo estos los indios los tengan por señores.... El problema más grave que se expone es, para los miembros de la Audiencia, la falta de la presencia de corregidores y alcaldes mayores dentro del distrito y jurisdicción. ." 51

Esta reflexión encierra uno de los excesos más graves que los encomenderos y eclesiásticos, impusieron como sistema contra los indígenas de los pueblos de Izalco y los de la provincia de San Salvador, pues como se desprende de lo anterior, pagaban los mismos naturales por aculturarlos al Rey, el encomendero, al fraile o clérigo, agregado, lo que les llevaban parientes, debidos y criados, como también, las contribuciones a las cofradías, los impuestos por los alcaldes indios, pagos a comerciantes por deudas de ropa, herramientas, etc. Las observaciones de Mejía denuncian que en los pueblos no todos estaban cristianizados ni bautizados, otros no sabían que cosa era Dios, por la ausencia de frailes y clérigos que buscaban los pueblos más numerosos de gente y ricos, dejando a un lado los que no presentaban sustanciosas ganancias terrenales. También denuncia el sistema en Tecuntlatan (Chiapas)." 52

\section{España ante la mirada de Europa}

La necesidad de aparentar de la sociedad guatemalteca y salvadoreña y la cortedad de salarios de los presidente y oidores, dio paso para que éstos buscaran medios para aumentar sus beneficios. Las denuncias hechas a Cerrato por poner en práctica las leyes nuevas, llegaron al extremo de acusaciones de apropiación indebida de riquezas y de favorecer a sus parientes, nepotismo. Entendemos que lo ejecutado por Cerrato, Ramírez y Mejía y otros oidores, fue por apremio del Rey en cumplimiento de sus mandatos, ante la insistencia del grupo de religiosos, así del distrito de Guatemala como del resto de las indias españolas, por aliviar a los indígenas de la esclavitud. La situación exterior de España en Europa, respecto al tratamiento que se hacía a los habitantes del

\footnotetext{
${ }^{51}$ Fuente: AGI.AG.Leg.9. Fol.389. Carta escrita por el oidor Mejía dirigida a su Majestad. 30-VII1557.

${ }^{52}$ Fuente: Edward O'Flaherty, S, J. Iglesia y sociedad en Guatemala. Pag. 154. Publicaciones del Seminario de Antropología Americana. Universidad de Sevilla. Vol. 17. 1984.
} 


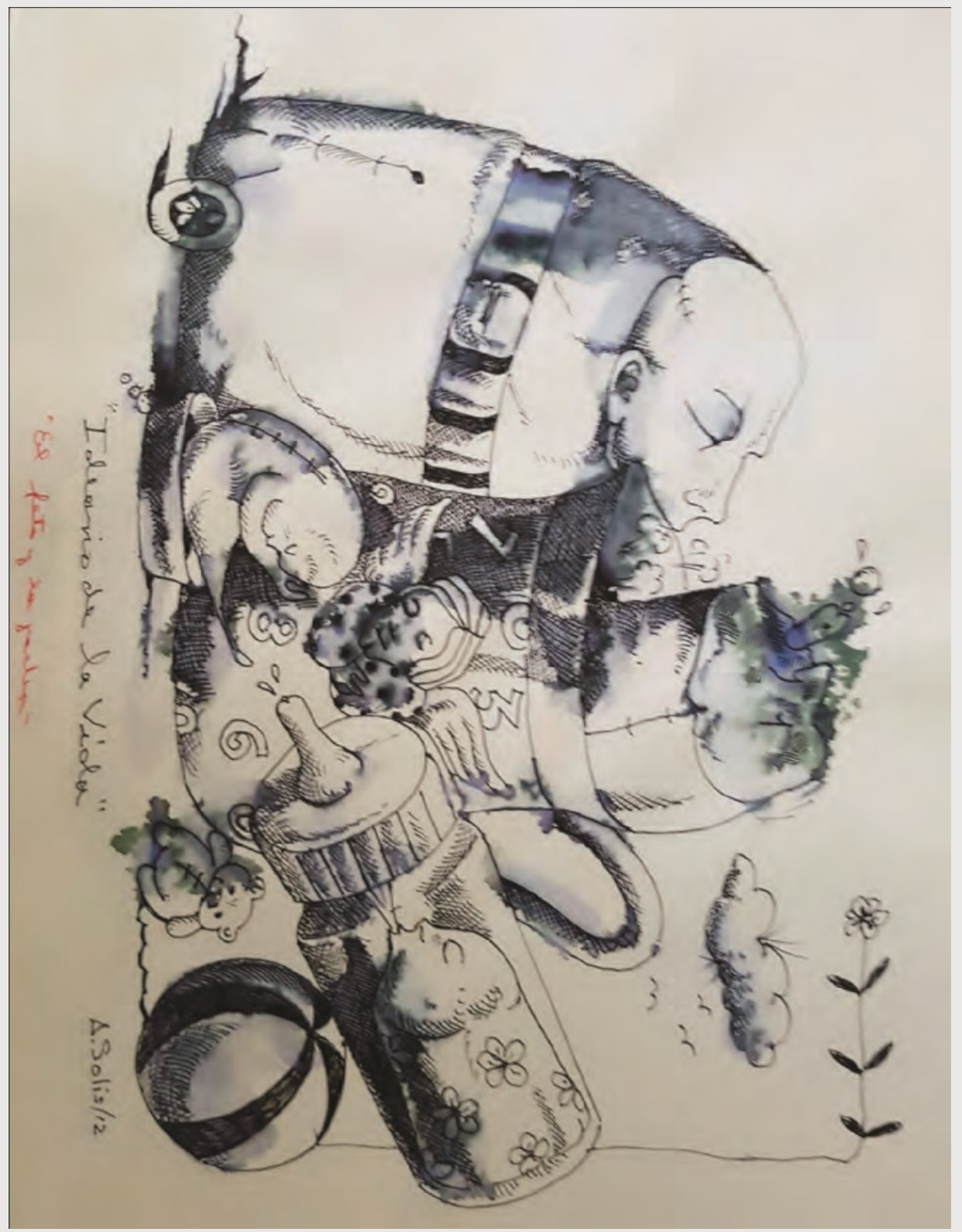

Armando Solis 
nuevo mundo, era cuestionada en los diferentes países. El Rey pretende quedar ante Europa como el líder de la civilización cristiano-católica, no es absurdo creer en ese apremio real. A la corona también le urgía convencer a Europa de que la conquista era más evangelizadora que explotadora.

El cumplimiento de las leyes, supuso también un cambio político entre eclesiásticos y encomendados, lo más curioso es, que de la noche a la mañana, se vuelven llenos de un sentido paternalista y humanitario, acerca del tratamiento de los indígenas encomendados, de esclavos son estimados como hijos. Los afligidos conquistadores encuestan el apoyo en el obispo, Tomás López, los que cortejaban a los presidentes ahora son los que acusan. El oidor Juan Méjía y Loaisa, como otros, no les quedo otro camino que favorecer aparientes y amigos, por lo cual recibio dádivas, usaron de los indios y actúan como tratantes, como cualquier mercader. En al caso de su ambición, les llevó incluso a asociarse con algunos encomenderos y entrar en negocios con Gómez Díaz de la Reguera, natural de Astorga, León, hijodalgo, de solar conocido, llego a la provincia de San Salvador en 1534, casado con Isabel Costilla, hija mestiza de Gaspar de Cepeda, conquistador-encomendero de Nahuizalco, Citalá y Guazapa, encomendero de Nahulingo, por breve espacio de tiempo, pero como comerciante, tenía estancia y cacaotal cercano al pueblo de encomienda, poderoso vecino de la ciudad de San Salvador, con intereses en los Izalcos, emprenderá una larga cruzada contra Juan de Guzmán y Diego de Guzmán y otros encomenderos de los otros pueblos de Izalcos, Mejía beneficio a Reguera con las tasaciones de sus pueblos, recibiendo cuantiosos obsequios, agregado, ciertos intereses sobre casar al doctor Mejía, con la hija de Luisa Corvera y 12 mil pesos de dote, que había de entregar, Gómez Díaz de la Reguera. Los bajos sueldos de los oidores dieron paso a la corrupción.

Pilar Sanchiz Ochoa (1976), considera que nos encontramos ante uno de los típicos casos coloniales de rápido resquebrajamiento de leyes, instituciones y, en definitiva, de una sociedad que acaba reconstituirse. En honor a la verdad, esta sociedad guatemalteca y salvadoreña no puede nunca compararse, ni siquiera ser objeto de comparación conceptual a las tradicionales sociedades del viejo mundo. Así tenemos que todos los sucesos son consecuencia lógica de los condicionantes impuestos por una tierra conquistada.

\section{Año 1558}

"Francisco del Valle, en nombre de la ciudad suplica se mande dar cédula y provisión real a la Audiencia, para que todas las veces que la ciudad o particulares pidiesen testimonio o fe de lo que ocurre, para informar a su magestad se les dé libremente y sin hacerles vejaciones." 53

\footnotetext{
${ }^{53}$ Fuente: AGI.AG.Leg.42. .- Fuente: Edward O'Flaherty, S, J. Iglesia y sociedad en Guatemala. Pag. 154. Publicaciones del Seminario de Antropología Americana. Universidad de Sevilla. Vol. 17. 1984. Fuente: AGI.AG.Leg.42.
} 
El 22 de febrero de 1558, vuelven los miembros de la Audiencia a "insistir" sobre la expansión de la jurisdicción de justicia Mayor de Sonsonate.

"El Doctor Mejía La otra, que el Juan de Guzmán, no resida como residen con su mujer, casa, cuñados y allegados en el dicho pueblo, pues es contra ordenanzas. La otra que se haga justicia de todos los excesos que él y su mujer, cuñados y allegados, parientes y sus negros y criados, hayan hecho en el dicho pueblo, después que le posee, la otra y esta es notable, que el recoger de los tributos, diez que no tienen cuenta, ni razón, ni quiere que se halle justicia, ni otra persona delante, sino que él, por su persona, pide a cada un indio, lo que le parece o quiere a su voluntad, y si esto es así, no solo recogerá lo contenido en la tasación, aunque como dicho es, excesivo, antes podrá recoger, quince y veinte mil pesos y cuanto quisiere, sin que se le pueda averiguar, ni probar por alguna vía y tiene los indios tan sujetos y amedrentados, que estado el presente por ninguna vía, se podría averiguar la verdad, asimismo, tiene en el dicho su pueblo y comarca ciertas milpas de cacao y otras granjerías e que además de los servicios personales que tiene los indios, son agraviados con estar los unos en haciendas y otros mesclados en las acequias y regadios y en el coger de los frutos, que están en su mano del y sus negros y criados, coger de las milpas comarcanas el cacao, que quisiese sin que los indios lo vean y aun que lo viesen no osaran pedirlo" 54

\section{2 de Febrero de 1558}

"Tres leguas del Puerto de Acajutla desta provincia de Guatimala, se a poblado una villa, donde hay ciento y cincuenta casas, todas de mercaderes y tratantes y se cree se aumentara cada día más, solía haber antes que esta Audiencia se fundase, en el puerto un Alcalde mayor, ágora se manda resida en este pueblo, que se llama trinidad, para que tenga en justicia la tierra y defienda los naturales, parece convenía también, pudiese visita los términos de la ciudad de San Salvador y San Miguel, que están a quince el un pueblo y el otro, treinta y cinco V.M. mande lo que fuere servido." 59

"Respuesta" que avisen si esta visita de términos es de los naturales y si es para servicios de ellos, para que efecto y sobre más particular razón de ello.

46. 23 de marzo de 1558. La ciudad de San Salvador, escribe a su Majestad. Nombramiento como procuradores a Blas Cota y Hernando Diego Quixada.

"El Consejo, Justicia y Regimiento de la ciudad de San Salvador, que es en la gobernación de Guatemala, hacemos saber a vuestra majestad, como luego que esta ciudad recibió y vido las cartas del Emperador, nuestro señor, y del serenísimo rey don Felipe, su muy caro de difuntos, como vuestra majestad lo manda en su real cédula, se provea en otra parte en

\footnotetext{
${ }^{54}$ AG Leg.9.Fol.384. Guatemala a 30 de julio de 1557. 59 AGI.AG.Leg.9. Fol. 395vº.
} 
manera que la dicha limosna, haya efecto y porque de los dichos, Blas Cota y Hernando Diego Quixada, vuestra majestad, sera informado de esta tierra muy largo y ampliamente, en esta no diremos más de que dios, nuestro señor, guarde a vuestra majestad muchos reynos y señorios, aumente como sus leales vasallos deseamos, de esta ciudad de San Salvador, veinte y tres de marcó. Católica Real Majestad, vasallos de vuestra majestad, sus reales pies y manos besamos. Luis Dubois, Francisco de Castellon, El Licenciado Diego Quizada, Lope Pardo, Cristóbal Salvago, Cristóbal Cerón-. " 55

\section{9}

16 de Abril de 1559. La Corona introduce otra innovación en su macro política indiana, al reducir el poder micro político del órgano rector del Distrito de Guatemala. El sentido de orden, el cambio, se estaba introduciendo en el Distrito, pues las continuas denuncias habían hecho eco en la Corona. Los vecinos y cabildo de la ciudad de San Salvador, nombran como procuradores de la ciudad, al doctor Blas Cota y el Licenciado Diego Quijada, vecinos y regidores de ésta, véase la "insistencia" de que sean oídos y favorecidos, solicitan se cumpla la limosna de la Corona para finalizar el Hospital.

29 de mayo de 1559, La princesa gobernadora regente, contesta al Doctor Mejía sobre la visita de San Salvador, que había informado en 1557. Por muerte del mensajero, no se habían recibido los autos, por lo que le pide los envié por traslado para que haga fe y se pueda ver y proveer lo que convenga.

El enriquecido Juan de Guzmán, pionero del "grupo de Salamanca", pretendía marchar a España, deja como heredero a Diego de Guzmán, su hijo. Finalizando el mandato de presidente interino, Pedro Ramírez de Quiñones, por muerte del Doctor Antonio Rodríguez de Quezada, previniendo la llegada del nuevo presidente Landecho, que toma posesión el 2 de septiembre de 1559, se le concedió real cédula de encomienda, siendo menor de edad, a Diego de Guzmán, contraviniendo las reales ordenanzas, gracias a la firme amistad entre el presidente interino y el prepotente encomendero.

\begin{tabular}{|l|l|}
\hline Nombre: & $\begin{array}{l}\text { Incidencias Encomienda Diego Guzmán Encomienda menor de edad,dada } \\
\text { por el presidente interino Pedro Ramírez de Quiñones }\end{array}$ \\
\hline $\begin{array}{l}\text { Diego de Guzmán. } \\
\text { Mitad de Izalco. }\end{array}$ & $\begin{array}{l}\text { Se le concedió real cédula de encomienda siendo menor de edad a Diego } \\
\text { de Guzmán, contraviniendo las reales ordenanzas, gracias a la firme } \\
\text { amistad entre el presidente interino y el prepotente encomendero. }\end{array}$ \\
\hline
\end{tabular}

Cuadro No.9. Incidencias Encomienda Diego Guzmán.

${ }^{55}$ AGI.AG.Leg.43. 
El 11 de agosto de 1559, se expidió el título de encomienda y se le entrega la mitad de Izalco, firman el Licenciado Palacios, el oidor Jofre de Loaysa y el secretario Diego de Robledo. Además de su influyente poder en la Audiencia de Santiago de Guatemala, en España, Juan de Guzmán mantenía amistad, con el Duque de Bejar y Duque de Sessa, con quien compartía mesa en Madrid, en sus viajes a la Península. En el Archivo General de Indias, Sevilla, está la residencia tomada al licenciado Pedro Ramírez de Quiñones, oidor de la Audiencia de Guatemala, por el: "licenciado Juan Martínez de Landecho, presidente de la misma Audiencia, juez nombrado para dicho efecto. Nota: Está incompleta la pieza y la residencia. 1 pieza" 56

El nuevo presidente escribe al Rey, participando que los indios naturales del Distrito de la Audiencia, los encontró bien tratados por los españoles y que si por ventura hay entre ellos algún desorden, nace de los clérigos vicarios, que residen en los pueblos, donde se coge cacao, tratan con ellos, y les son e hacen notables vejaciones, al tiempo de la cobranza y puesto que los prelados de quien depende el castigo de los susodichos, han sido avisados, no por eso se ha remediado, antes ha visto que en ese caso, son remisos y dan vado a las quejas que por los indios de este distrito cerca de ello ponen. El presidente sugiere, que la Corona provea a lo menos, en los pueblos de los Izalcos, donde el dicho cacao se coge, haya frailes en las dichas vicarias, para escuchar los dichos inconvenientes, pues es notorio que estos tales, a lo menos de la hermandad dominica y franciscanos, han hecho y hace mucho fruto en el aumento de la doctrina cristiana, enseñándola con mucha "policía" a los dichos naturales, que siendo esto así y mandándose que los provinciales de las órdenes susodichas, provean de numerarios de ellos, sería gran paso para ayudar a sostener los dichos naturales y en efecto se excusaría el inconveniente dicho. A lo anterior expuesto se contesta:

"que el obispo que tenga ciudado de hacer castigar a los clérigos que no viniesen en bien y la provisión que los frailes prediquen y estén donde quisieren." 62

En el Consejo de Indias, se estaba estudiando las medidas para expandir la institución de alcalde Mayor, por las constantes denuncias que llegaban a la Corona. Pero exigía el inconveniente de la longevidad de algunos conquistadoresencomenderos, como los descendientes de éstos, que continuaban presentando probanzas de méritos y servicios, para que el Rey, pagara el premio a los servicios prestado por sus padres, abuelos y tataranietos en la conquista. El Alcalde mayor de la villa de la Trinidad, es suspendido del oficio, mientras se resuelve por el Consejo las medidas a tomar. El 18 de diciembre de 1559 se remite una real provisión a la Audiencia de Guatemala:

"Solicitando informes a la Real Audiencia sobre el proyecto que el corregidor de Usulután tenga jurisdicción en las villas de San Miguel y Choluteca y sus términos,.."

Por cédula real dada el 9 de enero de 1560, se ordena que Yucatán, Cozumel y Tabasco sean de la Audiencia de México. El 19 de febrero de 1560, la Corona procede a nombrar

${ }^{56}$ Fuente: AGI. Signatura.Justicia.308. 62

AGI.AG.Leg.9 Fol. 415 ,

Universidad Tecnológica de El Salvador

REVISTA DE MUSEOLOGÍA KÓOT, 2017 AÑO 7, n. o 8, ISSN 2078-0664, ISSNE 2378-0664 
Alcalde Mayor en Yucatán, Tabasco y Cosumel al Licenciado Diego Quixada, en lugar del que había proveído la Audiencia, cuya residencia se le cometió.

\section{Pleito Gomes Díaz de la Reguera}

\begin{tabular}{|c|c|c|}
\hline $\begin{array}{l}\text { Gómez Díaz de la Reguera, natural de } \\
\text { Astorga, León, hijodalgo, de solar } \\
\text { conocido, llego a la provincia de San } \\
\text { Salvador en 1534, casado con Isabel } \\
\text { Costilla, hija mestiza de Gaspar de } \\
\text { Cepeda, conquistador-encomendero } \\
\text { de Nahuizalco, Citalá y Guazapa, } \\
\text { encomendero de Nahulingo, por } \\
\text { breve espacio de tiempo, pero como } \\
\text { comerciante, tenía estancia y cacaotal } \\
\text { cercano al pueblo de encomienda, } \\
\text { poderoso vecino de la ciudad de San } \\
\text { Salvador, con intereses en los Izalcos, } \\
\text { emprenderá una larga cruzada contra } \\
\text { Juan de Guzmán y Diego de Guzmán } \\
\text { y otros encomenderos de los otros } \\
\text { pueblos de Izalcos, Mejía beneficio a } \\
\text { Reguera con las tasaciones de sus } \\
\text { pueblos, } \\
\text { obsequios, agregado, ciertos intereses } \\
\text { sobre casar al doctor Mejía, con la hija } \\
\text { de Luisa Corvera y } 12 \text { mil pesos de } \\
\text { dote, que había de entregar, Gómez } \\
\text { Díaz de la Reguera. Los bajos sueldos } \\
\text { de los oidores dieron paso a la } \\
\text { corrupción. }\end{array}$ & Vecino & $\begin{array}{l}\text { Honrado y de buena casa en } \\
\text { España. Tiene casas criados } \\
\text { españoles, familia casa, caballos } \\
\text { y armas. Casado con Isabel } \\
\text { Costilla. Mestiza. Hija de india } \\
\text { que tuvo con Gaspar de } \\
\text { Cepeda." } 2\end{array}$ \\
\hline
\end{tabular}

Cuadro No.10- Pleito Gomes Díaz de la Reguera. 


\begin{tabular}{|c|c|c|}
\hline Nombre: & $\begin{array}{l}\text { Cargo. Cabildo ciudad de San } \\
\text { Salvador. } 1559 .\end{array}$ & Procedencia. \\
\hline Pedro de Benavides. & Alcalde Ordinario. & Castilla. \\
\hline Cristóbal Salvago. & Alcalde ordinario. & $\begin{array}{l}\text { "Cristobal Salvago } \\
\text { vecino de Sevilla. } 1498 . "{ }^{\prime}\end{array}$ \\
\hline Francisco Castellón. & $\begin{array}{l}\text { Vecino y regidor. } \\
\text { Testigo. 6/XII/1559. }\end{array}$ & $\begin{array}{l}\text { Edad. Más de } 55 \text { años. } \\
\text { "Francisco Castellón. } \\
\text { Hijo de Juan Castellon e } \\
\text { Ilarra de Castellón, } \\
\text { vecinos de Barcelona, } \\
\text { pasa en la nave de Miguel } \\
\text { Ferrer.1526." } 4\end{array}$ \\
\hline Alguacil mayor. & $\begin{array}{l}\text { Edad más de } 50 \text { años. } \\
\text { Vino en la Armada de Gil } \\
\text { González Avila. } 500 \\
\text { hombres y } 4 \text { capitanes. } \\
\text { Conquistando desde } \\
\text { puerto de caballos } \\
\text { llegaron a la mar del Sur. } \\
\text { Yde alli pasaron a } \\
\text { Guatemala- }\end{array}$ & \\
\hline \multicolumn{3}{|l|}{ Pleito Gomez Díaz. } \\
\hline $\begin{array}{l}\text { Casado con Isabel } \\
\text { Costilla. Mestiza. Hija } \\
\text { de india que tuvo con } \\
\text { Gaspar de Cepeda. }\end{array}$ & $\begin{array}{l}\text { Honrado y de buena casa en } \\
\text { España. Tiene casas criados } \\
\text { españoles, familia casa, } \\
\text { caballos y armas. }\end{array}$ & \\
\hline $\begin{array}{l}\text { Vecino San Salvador } \\
\text { Testigo. 6/XII/1559. }\end{array}$ & No tenemos datos. Castilla. & \\
\hline $\begin{array}{l}\text { Vecino San Salvador } \\
\text { Testigo. 6/XII/1559. }\end{array}$ & No tenemos datos. Castilla. & \\
\hline \multicolumn{3}{|l|}{ Escribano. 6/XII/1559. } \\
\hline $\begin{array}{l}\text { Vecino San Salvador. } \\
\text { Testigo.7/XII/1559. }\end{array}$ & $\begin{array}{l}\text { Edad: } 50 \text { años. De Santo } \\
\text { Domingo paso en la armada } \\
\text { de Gil González Avila a } \\
\text { Honduras que venía por } \\
\text { Capitán General. }\end{array}$ & \\
\hline $\begin{array}{l}\text { Alcalde. Testigo. } \\
\text { 7/XII/1559. }\end{array}$ & $\begin{array}{l}\text { "Cristobal Salvago vecino de } \\
\text { Sevilla. } 1498 . " \text { " }\end{array}$ & \\
\hline
\end{tabular}




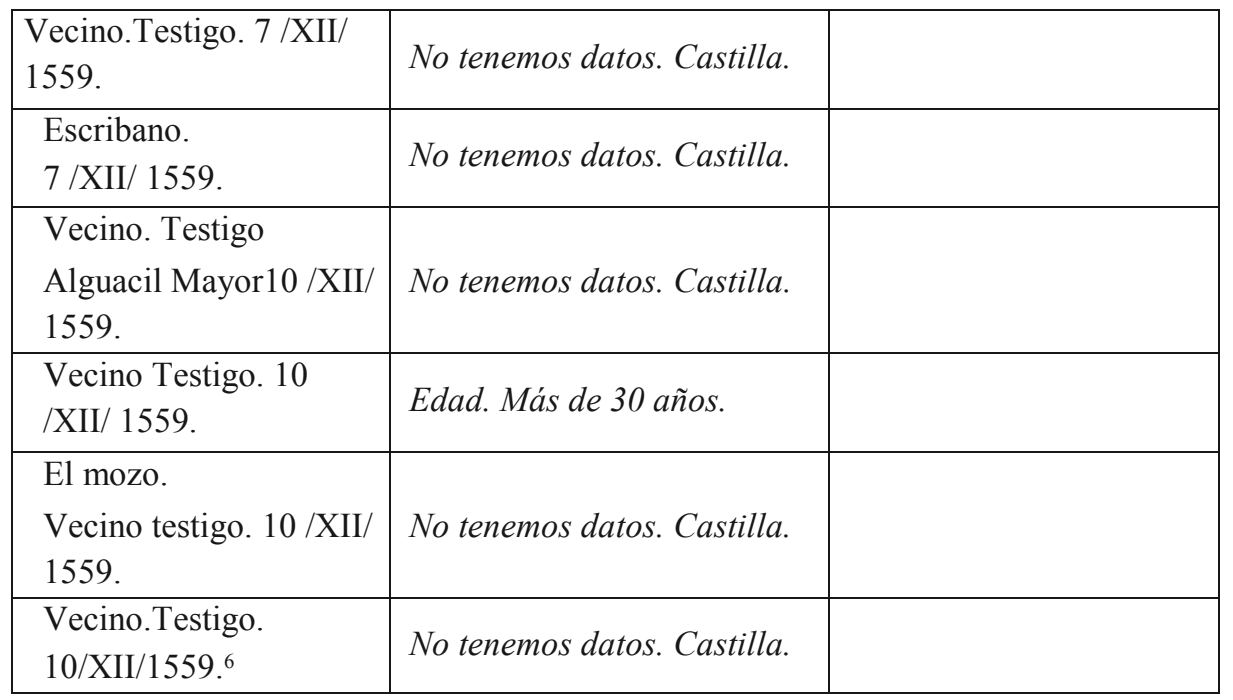

Cuadro No.11. Pleito de Gomez Díaz de la Reguera y su mujer. Con Gonzalo de Alvarado.

\begin{tabular}{|c|c|}
\hline "Gonzalo de Alvarado & $\begin{array}{l}\text { Vecino de Santiago le } \\
\text { quitaron Pueblo de Mixco y } \\
\text { mitades de Texutla y } \\
\text { Paramos, Acatenango. Por } \\
\text { mejoría. } 8 / \mathrm{I} / 1560 \\
\text { Encomienda mitad de } \\
\text { Naguizalco y Citala,por } \\
\text { muerte de Gaspar de Cepeda. }\end{array}$ \\
\hline Pedro de Obid & $\begin{array}{l}\text { Vecino de Santiago, por } \\
\text { mejoría, encomienda mitad } \\
\text { Naguizalco, por muert de } \\
\text { Gaspar de Cepeda. 9/I/1560. } \\
\text { se encomiende a otro sus } \\
\text { encomiendas de Alotepeque } \\
\text { Tescoaco,Teguantepeque. }\end{array}$ \\
\hline Francisco de Chávez & $\begin{array}{c}\text { Vecino ciudad de San } \\
\text { Salvador. Encomienda } \\
\text { Pueblo de Guazapa. Por } \\
\text { muerte Gaspar de Cepeda. } \\
\text { /10/I/1560. }\end{array}$ \\
\hline Ambrosio Méndez & $\begin{array}{c}\text { Encomienda de Guaymoco y } \\
\text { Tacachico 9/I/1560. }{ }^{7}\end{array}$ \\
\hline
\end{tabular}

Cuadro $\mathrm{N}^{\circ}$.12. Pleito Gomez Diaz. 


\begin{tabular}{|c|c|c|c|c|}
\hline 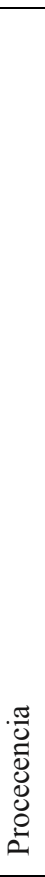 & 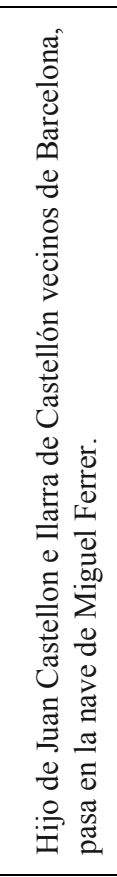 & 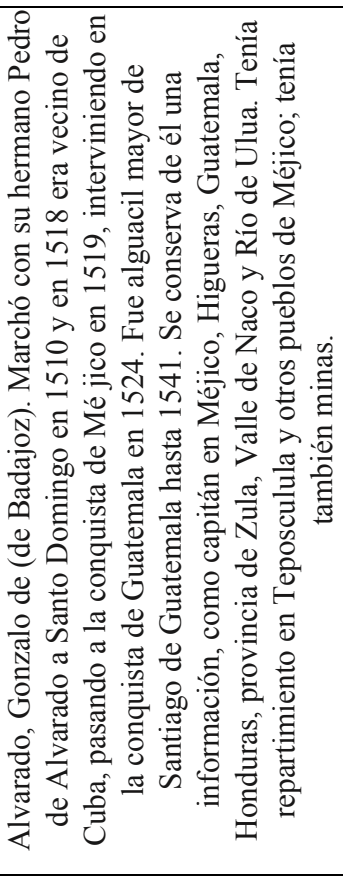 & & \\
\hline 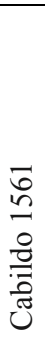 & 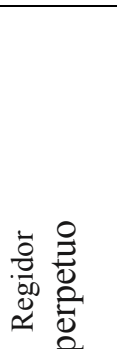 & 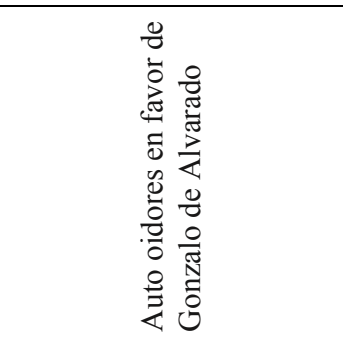 & & 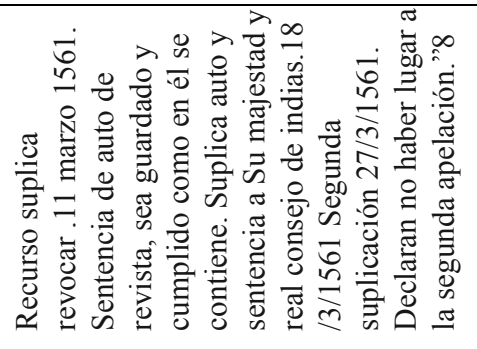 \\
\hline $\begin{array}{l}\text { ڤ̆ } \\
\text { है } \\
\text { Z }\end{array}$ & 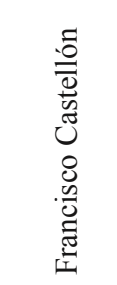 & 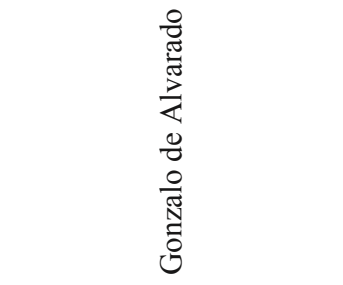 & $\begin{array}{l}0] \\
0 \\
0 \\
0 \\
0 \\
0 \\
0 \\
0 \\
0\end{array}$ & 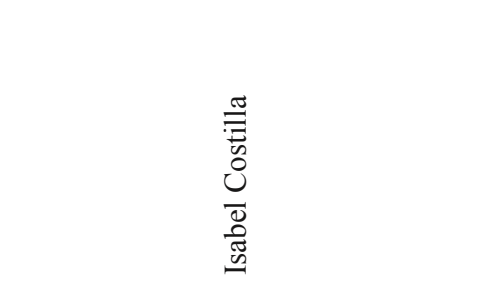 \\
\hline
\end{tabular}


"Macleod, 1973, 117, señala que Gómez Díaz de la Reguera tenía un ejército privado de trescientos negros, mulatos y mestizos con los que acosaba a la población local. "57

\section{0}

En 1560, el fiscal de la Audiencia de Guatemala, había remitido al Consejo de Indias la documentación:

"con el mariscal Pedro Núñez de Guzman, sobre la renunciación de los indios que tenía encomendados. ",58

Carta escrita por el Licenciado Landecho dirigida a su Majestad.

"La Audiencia. En esta Real Audiencia, se recibieron por el mes de junio, de este año de 1560, las cédulas y cartas y despachos que vuestra majestad envió y que no se provean alguaciles mayores.

11- Los pueblos de españoles de este Distrito, están lejos de esta Real Audiencia, y por no haber en todos alcaldes mayores, los indios comarcanos son maltratados y el remedio es dificultoso, convendría a vuestra Magestad mandase a que en cada uno de los pueblos de españoles, residiese un Alcalde Mayor que tuviese jurisdicción en toda la comarca y aun en algunos pueblos de indios principales, que están apartados, residiesen corregidores, aunque estuviesen encomendados en vuestra Real Corona, porque las justicias ordinarias, suelen ser remisas en casos de indios y los oidores, no pueden visitarllo todo, por ser pocos y la tierra muy larga y no se poder andan la tierra la mayor parte del año a causa de las aguas y así nos ha parecido que el Alcalde Mayor que está en el puerto de Acajutla y la villa de la Trinidad, tengan jurisdicción en la ciudad de Sant Salvador y su comarca, que está allí junto, y el corregidor de Ucelután, que está en vuestra real Corona, tenga jurisdicción en las villas de Sant Miguel y Choruteca y sus términos, y asimismo conviene esto, para la cristiandad y pulicia de los indios. "Respuesta" véase lo que se respondió en efecto.

Cerrato había introducido y expandido el cargo de Corregidor, en la provincia de San Salvador, con el nombramiento de corregidor de Usulután. Landecho y los ministros, proponen el expansionismo del control micro político de este funcionario en la provincia de San Salvador en 1560, en los términos orientales, que el corregidor de Usulután, que está en la Real Corona, tenga jurisdicción en las villas de San Miguel y Choluteca y sus términos, y asimismo, conviene esto para la cristiandad y "policía" de los indios. Se margina "véase o que se respondió en efecto". ${ }^{65}$

\footnotetext{
${ }^{57}$ Fuente: Macleod, 1973, pág. 117.

${ }^{58}$ Fuente: AGI. Justicia 1039. Una pieza. 1560/1572. Ramo 3. 65 Fuente: AGI.AG.Leg.9. Fol.423.-424.
} 
El 18 de julio de 1560 por Real Cédula, se pide a la Audiencia de Guatemala:

"Que la audiencia amplie el proyecto que remitiera al Consejo de indias sobre que el corregidor de Usulután tuviese jurisdicción en la villa de San Miguel y sus términos..." 59

6 de septiembre de 1560. "Real Cédula para que el licenciado Landecho tenga la gobernación de los Confines, como la tiene el visorrey.

"El Rey, Licenciado Landecho, nuestro presidente de la Audiencia Real de los Confines, que reside en la ciudad de Santiago, de la provincia de Guatemala. Por la satisfacción que tenemos de vuestra persona, y porque entendemos que ansí conviene a nuestro servicio y buena gobernación de esa tierra, habemos acordado, que vos sólo, tengáis la gobernación della, y proveáis los repartimientos de indios que se hubieren de encomendar y los otros oficios, que se hubieren de proveer, ansy como lo ha hecho hasta aquí, toda esa Audiencia. Por ende, por la presente vos damos poder y facultad, para que vos sólo, tengáis la gobernación desea tierra y de todo el distrito de esa mi audiencia; que por esta mi cédula, mando a los nuestros oidores della, que libremente os dexen entender en las dichas cosas de gobernación y proveer los dichos repartimientos e oficios, sin que se entremetan en ello, ni en cosa alguna dello, con vos, y la administren en aquellas cosas y de la manera que lo hacen los nuestros oidores de la nuestra Audiencia, que reside en la ciudad de México, de la Nueva España, y en la villa de Valladolid y ciudad de Granada, conforme a las ordenanzas que les están dadas. Y en las cosas aquellos y vos, proveyeres, sentenciardes y despachardes, firmar vos, con ellos, en el lugar que suelen firmar los presidentes. Fecha en Toledo, a diez y seis de setiembre, de mil e quinientos y sesenta años. Yo el Rey. Refrendada de Juan Vázquez. Señalada del licenciado don Juan Sarmiento, licenciado Castro, Licenciado Valderrama. "60

\section{Año 1561}

Fernando Muro Romero (1975:16), nos aclara que recibida en 1561 la "cédula del gobierno" por Landecho, participa el deseo de cumplirla con acierto. El monarca le anima en ejercerlo adecuadamente, pero el brusco cambio producido por la nueva forma de Gobierno, que separa a los oidores de su intervención en las tareas gubernativas a favor del presidente, no va acompañado de una clara relimitación entre los asuntos de gobierno y justicia, necesaria si se tiene presente que, con anterioridad, los presidentes y oidores dirigían al unísono la gobernación y administraban justicia en la Audiencia. Debido a esta inadecuación legislativa, continúan las disensiones

\footnotetext{
${ }^{59}$ Fuente: AGDCA. A1.23. Leg. 1512.Fol.270.

${ }^{60}$ Fuente: AGI.AG Leg.394. Lib. R.4. Fol.2-2V .
} 
entre los magistrados, causadas también en alguna ocasión por una defectuosa interpretación de la "cédula de gobierno" por parte del Presidente Landecho.

Para finalizar con estos incansables conflictos de competencia, se pide a las autoridades mexicanas, un dictamen aclaratorio sobre los asuntos incluidos dentro de las funciones de gobierno. El fiscal de la Audiencia, por su parte, escribe al Consejo de Indias, en demanda de una definitiva solución sobre el contenido de las funciones judicial y gubernativa. No hay contestación real a estos importantes problemas.

Landecho, responde a la real cédula, de fecha 18 de julio de 1560, el 4 de junio de 1561 a la Corona, que de acuerdo a lo ordenado que de relación de los pueblos españoles y naturales, e la orden de gobernarse y si hay proveídos Alcaldes mayores que los tengan en justicia participa:

"Que Chiapa se gobierna por alcaldes ordinarios y está setenta leguas de Guatemala y son los alcaldes encomenderos, remisos a la justicia y buen tratamiento de los indios. Conviene poner a ley, un alcalde mayor, porque sin embargo de esto, hay en aquella comarca mucha merma de indios y tiene gran necesidad de gobierno y que se les guarde y haga justicia. Sobre este punto, ya vimos, como los conquistadoresencomenderos, gozan de privilegios de la Corona y por esta fecha, aún está muy lejos por parte de la misma, el querer imponerles la presencia de funcionarios reales, por los condicionamientos de conquista. Por ello, se responde "Que por ahora no se haga novedad". ${ }^{61}$

Respecto a la ciudad de San Salvador y villa de Jerez de San Miguel de la Choluteca, informa haber el mismo inconveniente que en Chiapas, pide haber por ley, otro alcalde mayor, y en estas partes hay pueblos vacantes en la real Corona, que se provean para ellos corregidores, con salarios. Landecho sugiere, que si en efecto se pusieran alcaldes mayores que los gobernasen y tuviesen en justicia, podrían con el salario de algunos de estos corregimientos y con algo más, que de la real caja les diera, servir los dichos oficios y repartimientos, alguna cantidad de pesos de oro, de los sobrantes de tributos de las comunidades de los mismos indios, que son ricos muchos de ellos, lo darán sin pesadumbre, se sustentara todo bastantemente. La respuesta es la misma de arriba: "Idem".

A Guatemala informa el presidente, que se había puesto en los pueblos de naturales del distrito, por haber comunidad y aparejo, alcaldes ordinarios y regidores de los mismos indios y éstos tienen la justicia muy limitada, que no entienden sino en cosas de poca importancia, que toca a los dichos indios y vecinos de cada uno de los dichos pueblos.

${ }^{61}$ Fuente: Fernando Muro Romero (1975:16). 
Por esta fecha, las necesidades de micro política de la Audiencia, había vuelto a proveer alcaldes mayores, y así lo informa el presidente. En cada una de las provincias de Soconusco, Nicaragua y Honduras, hay un alcalde Mayor, en la villa de la Trinidad y Puerto de Acajutla otro, en el partido de Zapotitlán, los Suchitepeques y la costa, hay un juez, que desagravia a los indios y conoce de las causas que hay y hace justicia.

$1^{\circ}$ de febrero de 1563, el presidente Juan Martínez de Landecho, es denunciado por participar en negocios de cacao, malversación de fondos, nombramientos de corregidores y dar ayudas de costa a parientes y amigos, según lo ordenado por la Corona, envía la relación de los oficios de Corregimientos y ayudas de costa que había dado el año de 1563:

La Corona en su macro política, realiza los cambios al suprimir la Audiencia de Guatemala y su traslado a Panamá, pero eso es otra historia.

Para finalizar esta investigaciones hago mención que algunos investigadores que han tratado el tema de los esclavos en Sonsonate, escriben que en 1563, se activó el tráfico de esclavos negros procedentes de Panamá y Nicaragua en el puerto de Acajutla, por su actividad comercial con Guatemala y el cacao que entra en su etapa de decadencia y la explotación del añil de la provincia de San Salvador. En los archivos de la memoria histórica de Sonsonate Archivo del Rey se encuentran documentos de la actividad de comercio de esclavos, que se intensifican a partir del siglo XVII. Tema que han tratado otros investigadores y que no es parte de nuestro estudio.

\section{Conclusión}

- La presencia de los castellanos y llamados luego españoles, en el Reino de Guatemala, provincia de San Salvador y Honduras, en las primeras décadas del Siglo XVI, ocuparon a los indígenas en la explotación de las minas y ríos, en busca del oro, se esclavizaron y vendidos en el Caribe, como lo denunciaron Las Casas y Marroquin, Alvarado introdujo los primeros Negros, Montejo hizo lo mismo en Honduras por comunicar el camino de Puerto de Caballos al Golfo de Fonseca y explotación de minas. Maldonado hizo lo mismo. Los vecinos de la Villa de San Salvador y posteriormente ciudad, hicieron lo mismo al introducir esclavos negros en los pueblos de los Izalcos y provincia de San Salvador. A partir de 1563 se encuentra documentación en los archivos de Sonsonate pero el aumento de la población negra se estudia mayoritariamente desde el siglo XVII, XVIII hasta la declaración de la libertad de los esclavos en El Salvador.

- Los indígenas de los pueblos indígenas de la provincia de San Salvador, continuaron esclavizados por el sistema introducido en la explotación de su economía agrícola, que era para pagar los tributos y mantener a los españoles durante los siglos de la colonización española, cuyo sistema aun continuo contemporáneamente. 


\section{Referentes bibliográficos}

Alfonso Franco Silva. Los esclavos de Sevilla. Diputación provincial de Sevilla.1980. Véase: Antonio Moreno Otero. Luis de Peraza: "historia de Sevilla"

Alfonso Franco Silva. La esclavitud en Sevilla y sus tierras a fines de la edad media.

Jesús Cosano. Los negros curros. Sevilla y Cádiz se llenan de esclavos negros. 3 marzo 2017.

Anales eclesiásticos y seculares de la muy noble y leal ciudad de Sevilla... Que contiene sus muy principales memorias desde el año 1246... Hasta el de 1671... Caja de ahorros provincial de San Fernando de Sevilla. 1987.

Diego Ortiz de Suñiga. Análisis eclesiásticos de Sevilla.1677.

Francisco Morales Padrón. La ciudad del quinientos. 1977.

María del Rosario Santos Cabota. El mercado de esclavos en la primera mitad del siglo del siglo XVIII. Colaboración antigua hermandad de los negritos de Sevilla. Isidoro Moreno.

Mariza Vega Franco. Tráfico de Esclavos con América. (Asientos de grillos y Lomeli.)Sevilla. Escuela de Estudios Hispano-americanos. 1984.

Enriqueta Vilar Vilar. El consulado de Sevilla. Asentistas de esclavos: una nueva tentativa para el monopolio comercial. Universidad Hispanoamericana Santa María de la Rabida.y otros. Huelva 1980.

Isidoro Moreno La antigua hermandad de los negritos de Sevilla. Etnicidad, Poder y sociedad en los 600 años de historia. Universidad de Sevilla y junta de Andalucia. Sevilla 1997.

\section{Footnotes}

1 Fuente: AGI.AG.Leg.128.Fols.196-202v ${ }^{a}$.

2 Fuente: Francisco Castellón Archivo General de Indias, CONTRATACIO N,5536,L.2,F.21(3) - 1 - Imagen Núm: 1 / 1. Fuente: AGI. Justicia Leg. 285 11 Pleito de Gomez Díaz de la Reguera y su mujer. Con Gonzalo de Alvarado. Sobre los indios de Naguizalco, Citala y Guazapa. 1559-1565.

Fol.47 y 47v $v^{\circ} .48-48 v^{\circ}-49$. Encomienda Naguizalco Jorge de Alvarado. Pedro y Jorge de Alvarado Capitán General de Guerra encomienda Guazapa y Citala.

3 Fuente: Incitativa para que don Juan de Silva, conde de Cifuentes y asistente de Sevilla, resuelva la demanda de Cristóbal Salvago, vecino de dicha ciudad, Archivo General de Simancas, RGS,LEG, 149805,56

4 Fuente: Francisco Castellón Archivo General de Indias, Contratación, 5536, L.2, F.21 (3)...Y digo que todos son hidalgos y limpios para poder ir en este viaje conforme a las ordenanzas de la casa de contratación.

Inicio del formulario 
5 Fuente: Incitativa para que don Juan de Silva, conde de Cifuentes y asistente de Sevilla, resuelva la demanda de Cristóbal Salvago, vecino de dicha ciudad, Archivo General de Simancas, RGS,LEG, 149805,56.

6 AGI.Justicia.Leg. 285.

7 Idem. Fuente: Francisco Castellón Archivo General de Indias, CONTRAT ACION, 5536,L.2,F.21 (3) - 1 - Imagen Núm: 1 / 1.

8 Fuente: Francisco Castellón Archivo General de Indias, CONTRATACIO N,5536,L.2,F.21 (3) - 1 - Imagen Núm: 1 / 1. 


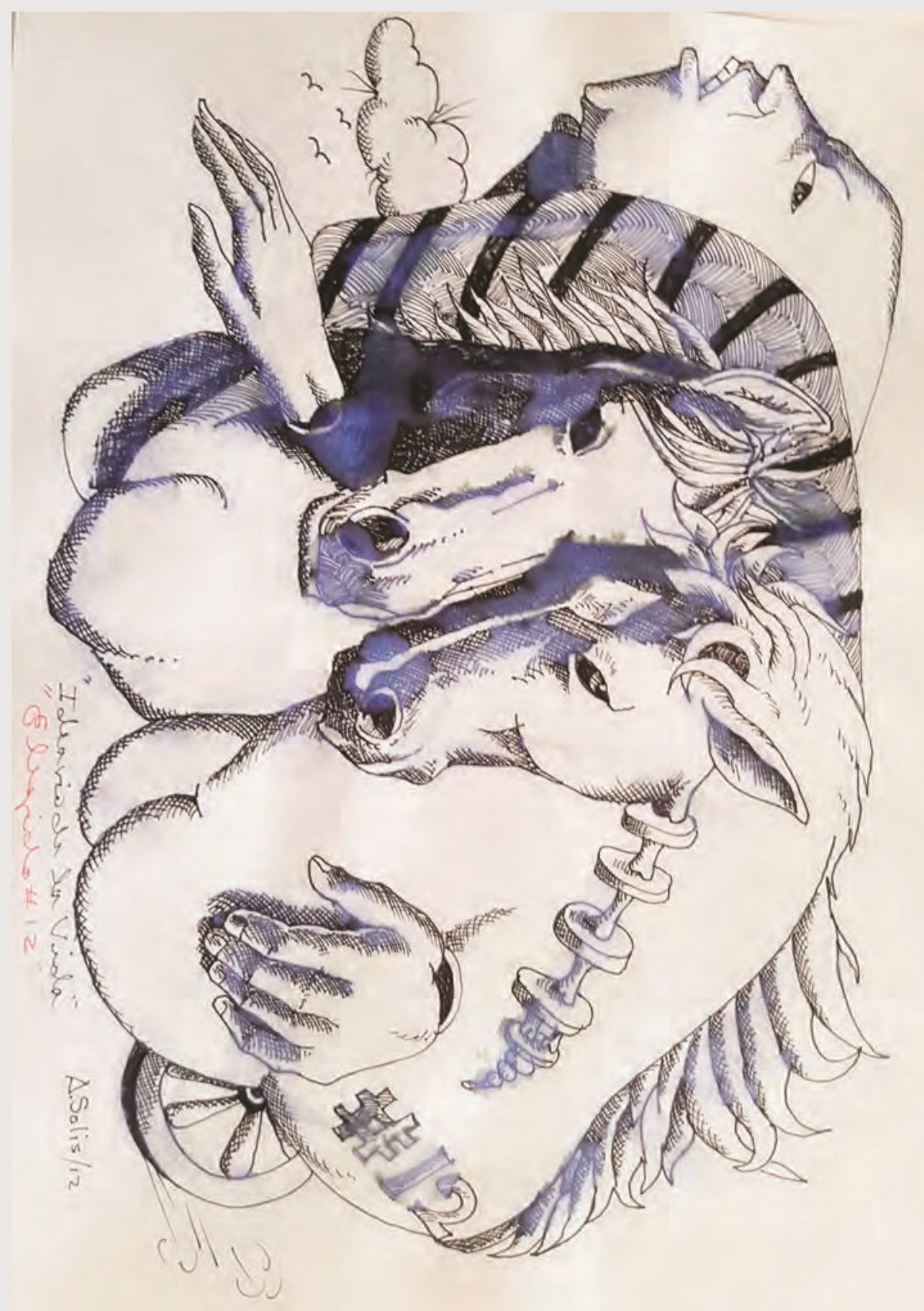

Armando Solis 